\title{
Do investors care about corporate tax?
}

Article

Accepted Version

Brooks, C., Godfrey, C., Hillenbrand, C. and Money, K. (2016) Do investors care about corporate tax? Journal of Corporate Finance, 38. pp. 218-248. ISSN 0929-1199 doi: https://doi.org/10.1016/j.jcorpfin.2016.01.013 Available at https://centaur.reading.ac.uk/53280/

It is advisable to refer to the publisher's version if you intend to cite from the work. See Guidance on citing.

To link to this article DOI: http://dx.doi.org/10.1016/j.jcorpfin.2016.01.013

Publisher: Elsevier

All outputs in CentAUR are protected by Intellectual Property Rights law, including copyright law. Copyright and IPR is retained by the creators or other copyright holders. Terms and conditions for use of this material are defined in the End User Agreement.

\section{$\underline{\text { www.reading.ac.uk/centaur }}$}

\section{CentAUR}

Central Archive at the University of Reading

Reading's research outputs online 


\title{
Do investors care about corporate taxes?
}

\author{
Chris Brooks ${ }^{\mathrm{a}, *}$, Chris Godfrey ${ }^{\mathrm{a}}$, Carola Hillenbrand ${ }^{\mathrm{b}}$, Kevin Money ${ }^{\mathrm{b}}$
}

a ICMA Centre, Henley Business School, University of Reading, Whiteknights, Reading RG6 6BA, United Kingdom

b John Madejski Centre for Reputation, Henley Business School, Greenlands, Henley-on-Thames, Oxfordshire RG9 3AU, United Kingdom

* Corresponding author.

E-mail addresses: c.brooks@icmacentre.ac.uk (C. Brooks), C.Godfrey@icmacentre.ac.uk (C. Godfrey), carola.hillenbrand@henley.ac.uk (C. Hillenbrand), kevin.money@henley.ac.uk (K. Money).

\begin{abstract}
This paper conducts a comprehensive examination of the link between corporation tax payment and financial performance in the UK. We find no discernible link between tax rates and stock returns for the UK, no matter how tax payment is measured. This is true throughout the sample period and for both customer-facing and non-customer-facing companies. However, allowing for industry norms and a host of firm characteristics, companies with lower effective tax rates have significantly higher levels of stock market risk. Firms that are reported in the newspapers in a negative way in relation to their level of corporation tax payment experience small negative stock returns, which are partially reversed within a month. However, the initial negative effects and subsequent rebound are both more pronounced for smaller companies. News announcements of the potential involvement of a firm in a corporate inversion (expatriation) result in steeper and much longer-lasting falls in share prices, whereas news stories of a more general nature relating to a firm's tax avoidance or tax payments have little noticeable effect.
\end{abstract}

Keywords: corporation tax, tax avoidance, stock returns, tax news stories

JEL classification: G12, G28, H25, H26 


\section{Introduction}

\subsection{Background and motivation}

Interest in the amount of tax a firm pays has been expressed by an increasingly broad array of stakeholders, including not only shareholders and the tax authorities but also customers, suppliers, employees, NGOs and the public at large. It is clear that perceptions of the acceptability of tax avoidance $^{1}$ have changed, perhaps permanently, so that practices that were previously deemed part of sensible planning are no longer socially acceptable in the UK. Firms that are perceived to be 'shirking their responsibility to pay their fair share of tax' can be subject to widespread opprobrium in the media. A decade and a half ago, an article in The Economist reported that 'Rupert Murdoch's News Corporation, which has earned profits of $£ 1.4 \mathrm{bn}(\$ 2.3 \mathrm{bn})$ in Britain since 1987 [has] paid no corporation tax there'. ${ }^{2}$ So the issue of multinational tax avoidance is not a new one and seems unlikely to disappear or to be resolved any time soon.

More recently, perhaps the most high-profile illustrations of the extreme negative publicity that can result from alleged tax avoidance relate to the US companies Amazon, Google and Starbucks. ${ }^{3}$ The latter firm, for example, reported losses on its UK business in 14 of its first 15 trading years in the country, despite having a market share of over $30 \%$ and, it was alleged, being inconsistent with its shareholder reports, which suggested high profitability in that market (Kleinbard, 2013). Starbucks paid $£ 8.6 \mathrm{~m}$ in UK corporation tax on UK revenue of $£ 3.4 \mathrm{bn}$ over the 15 -year period, a situation that arose mainly from intra-group charges: royalties and licence fees; mark-ups on coffee and interest on a loan from the US parent company (Kleinbard, 2013, p. 1520). When this was broadcast in the media, the company suffered significant reputational damage resulting in customer boycotts, which prompted it to voluntarily increase its UK corporation tax payments and to relocate offices to the UK (Christensen et al., 2015).

The UK's House of Commons Public Accounts Committee was convened in 2012 to examine the corporation tax payments of Amazon, Google and Starbucks, following the public outcry. The Committee lamented a 'complete lack of transparency in the amount of tax paid by multinational

\footnotetext{
${ }^{1}$ Tax avoidance refers to actions that firms or individuals take within the law to reduce their tax bills, which may include the setting up of specific structures or the exploitation of loopholes in the legal framework. Tax avoidance covers a very broad range of strategies from accessing government-backed incentives through structuring commercial transactions in tax efficient ways to the use of third-party financial products that deliver a specific tax outcome with minimal other commercial rationale, some of which will be more or less acceptable among various stakeholders although may be within legal boundaries.

${ }^{2}$ The mystery of the vanishing taxpayer, The Economist, 27 January 2000. www.economist.com/node/276945

3 See www.independent.co.uk/news/business/news/starbucks-suffers-first-uk-sales-fall-after-tax-row9284988.html\#
} 
companies'. ${ }^{4}$ However, despite the public grilling that these firms were subjected to at the time, there were no formal investigations or further actions and trade now appears to be as brisk as ever. Therefore, whether firms suffer permanent or transitory damage even in the most severe cases of 'getting caught', avoiding tax is, as yet, an unresolved empirical question.

Although the short-term media furore over these companies has died down, corporate tax has become an issue that refuses to go away, partly perhaps as a result of the dawning realisation that fiscal austerity is set to remain for the foreseeable future. During the post-financial crisis era, the financial positions of many governments in Europe and worldwide have yet to establish an entirely stable footing, with national debts still increasing. ${ }^{5}$ There is a widespread popular belief that if firms paid more tax, fiscal deficits could be reduced and/or spending cuts avoided. The 'tax gap' - the difference between the amount of tax that should be obtained if all payments were made as expected by law and the amount that the government succeeds in collecting - was put at $£ 34 \mathrm{bn}$ in $2012-13$ by HMRC. ${ }^{6} \mathrm{~A}$ Tax Research UK report for the Public and Commercial Services Union put the figure much higher at close to $£ 120 \mathrm{bn},{ }^{7}$ although HMRC have retorted that this higher estimate is 'over-inflated, flawed and muddled' ${ }^{8}$

Governments themselves are involved in a game where they trade off corporation tax revenue in anticipation of higher employment and other taxes from additional economic activity if foreign direct investment is encouraged by a favourable regime. As a result, global average corporation tax rates have fallen year-on-year from $27.5 \%$ in 2006 to $23.6 \%$ in 2014, and average rates have also fallen in every continent. ${ }^{9}$ This raises the spectre of tax competition between countries in a race to the bottom', where each individual country faces a prisoner's dilemma situation and the resulting lack of co-ordination implies that over time the amount of corporation tax paid globally declines - see, for example, Devereux et al. (2008). ${ }^{10}$ Of course, firms make location decisions not only on the basis of tax rates, but also taking into account a host of other factors including political and economic stability, regulatory frameworks, workforce skill levels, and natural resourcing levels. Evidence suggests that these other variables outweigh the influence of tax (Rondinelli and Burpitt, 2000), although tax rates are important in influencing where firms choose to locate their debt (Arena and Roper, 2010) but economic success cannot be guaranteed by merely establishing a low corporation tax rate. In general there is a lack of correlation between corporate tax rates and aggregate investment within a country

\footnotetext{
${ }^{4}$ HMRC Annual Report and Accounts 2011-12, 28 November 2012.

${ }^{5}$ See www.cityam.com/1413899944/public-sector-borrowing-five-charts-perfectly-sum-up-uk-finances for an analysis of the UK position as at October 2014.

${ }_{7}^{6}$ www.gov.uk/government/statistics/measuring-tax-gaps-tables

${ }^{7}$ www.taxresearch.org.uk/Blog/2014/09/22/new-report-the-tax-gap-is-119-4-billion-and-rising

${ }^{8}$ www.accountingweb.co.uk/article/hmrc-dismisses-new-tax-gap-estimate/564454

${ }^{9}$ Corporate tax rates table, KPMG, 2014.

${ }^{10}$ Interestingly, research suggests that global corporation tax takes have been relatively stable despite both declining nominal tax rates and increasing income shifting to low-tax jurisdictions (Dharmapala, 2008).
} 
over time (Hanlon and Heitzman, 2010). But at the margin fiscal considerations may make the difference in situations where the other variables are similar (Morisset and Pirnia, 2000).

Which kinds of firms are more likely to be 'aggressive' tax avoiders, and to make the most use of low tax locations? Academic research has highlighted a number of intuitively plausible firm characteristics that are positively correlated with avoidance, including: having more international activities, being a large firm, having high $R \& D$ expenditure as a proportion of sales and being technology intensive (Desai et al., 2006; Graham and Tucker, 2006), having a lower return on asset (ROA) and spending less on advertising (Dyreng et al., 2008). Firms that are more profitable have greater incentives to reduce their corporate taxes, which are levied as a percentage of those profits (Dunbar et al., 2010). Capital intensive firms, often measured by a normalised estimate of their property, plant and equipment (PPE), may have greater tax avoidance opportunities, partly related to the depreciation of these assets. Firms that are more leveraged also tend to be greater tax avoiders (Harrington and Smith, 2012), and tax avoidance is also linked with other measures of a firm's degree of corporate social responsibility (Huseynov and Klamm, 2012).

The avoidance of corporation tax is often believed to be a problem primarily with large companies operating simultaneously in many countries. The size (however defined), scope and complexity of multinational corporations have increased to the point where they are bigger than many nation states. For instance, even by the turn of the century, the largest 100 companies in the world controlled assets of over $£ 3$ trillion, of which $40 \%$ were located outside their home countries (Sikka and Willmott, 2010, p.345). Large multinationals are able to use a variety of means to reduce their tax payments that are not available to smaller, domestic firms, and thus a further key concern surrounding tax avoidance is that businesses of different sizes cannot compete on a level playing field. ${ }^{11}$ Against this backdrop, when personal taxation rates are increasing and government expenditure curtailed, it is perhaps unsurprising that there is heightened interest in ensuring that companies pay their 'fair share' of the tax burden.

From the outside, it seems possible to think of the payment of corporation tax in a particular country as a choice variable for a multinational firm, which can opt to pay more or less as it feels appropriate by expending more or less effort in organising its activities to avoid it. ${ }^{12}$ At the same time, the scope for firms to discreetly reduce their tax bills through avoidance measures while remaining under the radar is declining. Widespread use of social media means that any corporate transgressions, or perceived transgressions, can result in almost instant adverse publicity. In order to meet with societal expectations, it may be that firms need to not only pay any taxes that are legally required, but also act

\footnotetext{
${ }^{11}$ See www.oecd.org/tax/beps-about.htm

${ }^{12}$ Following the negative publicity, documented above, that they received in the media, Starbucks have taken the unprecedented step of voluntarily paying more tax than is required by law in the UK in an effort to try to repair their reputation (see http://www.starbucks.co.uk/our-commitment).
} 
within the spirit of the relevant legislation and not engage in activities or create artificial structures solely for the purpose of avoiding tax. This view is contested, for example by Hasseldine and Morris (2013), who argue that any distinction between the letter and the spirit of the law is unhelpful because the spirit of the law may be open to various interpretations and if the lawmaker wanted a different outcome then they should have drafted the legislation differently or more tightly.

Can activism by the general public or by charities bring about changes in the corporate tax behaviour of large international companies? Research undertaken by ActionAid found that the FTSE 100 group of firms had more than 8,000 subsidiaries, or over a quarter of the total, located in tax havens. The charity produced a report and lobbied firms to disclose the locations of all of their subsidiaries. This is required under UK law following the Companies Act 2006, which is more stringent than its US counterpart where only significant subsidiaries must be listed. Despite being required to do so by law, ActionAid found that the vast majority of the UK's top 100 companies did not comply. Even stating the numbers and locations of subsidiaries can constitute vital information that enables tax authorities to better allocate their resources available for scrutiny (Mills, 1998).

ActionAid pressured firms by threatening the possibility of negative media attention that could damage the firm's relationships with its customers, employees, suppliers, the government and the tax authorities. This also led to an investigation by the Business Secretary Vince Cable, and the story was picked up by all the major news media in the UK on 12 October 2011 (Choy et al., 2014). Dyreng et al. (2014) found that effective tax rates for firms which ActionAid identified as non-compliant with the disclosure rule rose by 3.7 percentage points subsequently, relative to those firms that were already compliant. They also found that relative to compliant firms, non-compliant ones reduced the proportion of their subsidiaries located in tax havens. Although Dyreng et al. attribute these changes in firm behaviour to the activities of ActionAid, it is possible that they would have occurred anyway even in the absence of their report, albeit over a longer time period, as a result of the high profile corporate tax scandals and changes in public mood regarding the acceptability of tax avoidance.

In the UK, the environment is such that firms are required to calculate their own corporation tax based on a self-assessment and to report this to HMRC. If HMRC are not satisfied with the information provided or require further details, they can open an enquiry (MacPherson et al., 2009). The potential risks for firms who fail to 'get it right' are numerous and include financial penalties if any evidence of wrong-doing is found, as well as the operational costs and adverse publicity arising from having to deal with an investigation. Set against the evidence reported by ActionAid described above, businesses are increasingly disclosing tax-related information beyond the minimal requirement in their annual reports and corporate social responsibility (CSR) reports with the hope that this will contribute to the reader's understanding of their tax position, pre-empt questions and enhance the 
standing of the organisation. ${ }^{13}$ More than half of FTSE 100 firms are expecting to become more transparent in their tax reporting, and over a third say that they already are more transparent following the media attention discussed above. ${ }^{14}$ Firms that voluntarily disclose more information (on historical results, non-financial statistics, background information and a summary of historical results) in their annual reports than the statutory minimum have lower cost of equity capital estimates in some cases (Botosan, 1997), indicating the importance of information in reducing the 'estimation risk' that investors face when they attempt to determine the worth of a firm.

The corporation tax rate has declined in the UK over the past 25 years, and arguably with it some of the incentive to incur the costs and risks associated with tax avoidance, from a high of $52 \%$ of taxable profits in 1982 to $20 \%$ in 2015 , which made the UK rate the joint lowest in the G8. ${ }^{15}{ }^{16}$ This has helped to make the UK an attractive place to do business, with fewer large companies than ever looking to move their tax residence out of the UK and an increasing number of foreign-owned companies considering moving in. ${ }^{17}$

Legislation is adapting in an attempt to get to grips with tax avoidance following shifts in business practices and the growth of multinationals, but arguably at a rather slow pace. Internationally, the OECD brought out its Base Erosion and Profit Shifting (BEPS) report in February 2013, which sought to 'look at whether or not the current rules allow for the allocation of taxable profits to locations different from those where the actual business activity takes place, and what could be done to change this if they do. ${ }^{18}$ There then followed a 15 -point action plan to address these issues including a proposal for stricter transfer pricing documentation for multinational companies. ${ }^{19}$ It seems that this relatively new legislation is having an effect on the tax policies of firms but the full impact is still feeding through.

The UK government introduced the General Anti-Abuse Rule (GAAR) in 2013, which tries to deter tax avoidance structures ${ }^{20}$ by 'focusing on the economic substance rather than the legal forms of tax avoidance schemes. ${ }^{21}$ According to a survey of tax decision-makers at large UK-listed companies, the

\footnotetext{
${ }^{13}$ Responsible tax: an integrated approach to tax transparency, Deloitte, 2014.

${ }^{14}$ KPMG annual survey of tax competitiveness, December 2014; and Deloitte European tax survey, 2014.

15 Alongside Russia (currently suspended from the G8), see www2.deloitte.com/content/dam/Deloitte/global/Documents/Tax/dttl-tax-corporate-tax-rates-2014.pdf

${ }^{16}$ Tax rates in the United States have remained at roughly the same level while they have fallen in many other places so that, relatively, the former have increased. The net effect for the United States has been an increase in the amount of income shifted out of the country (Klassen and Laplante, 2012). At the same time, foreign regulatory and compliance costs have risen as more and more countries, for example, insist that transfer pricing documentation is drafted.

${ }_{17}^{17}$ KPMG Annual survey of tax competitiveness, December 2014.

${ }^{18}$ See www.oecd.org/tax/beps-about.htm

${ }^{19}$ See Tax: insights for business leaders, EY, December 2014.

${ }^{20}$ www.parliament.uk/business/publications/research/briefing-papers/SN06265/tax-avoidance-a-generalantiabuse-rule

${ }^{21}$ Sikka and Willmott (2010).
} 
GAAR is believed to be effective by $84 \%$ of respondents, but over half believe that it could also pick up genuine commercial transactions. ${ }^{22}$ In addition, firms bidding for large central government contracts are required to have been free from outward signs of tax avoidance for the previous decade, although this is applied at the level of the individual bidding subsidiary rather than the whole company. ${ }^{23}$

Our research aims to make several important contributions to the literature. First, this paper represents the first comprehensive examination of the link between corporation tax payments and various measures of stock market performance outside the US. The academic literature on the various issues surrounding corporation tax and its links with firm characteristics, discussed in detail below, is now quite substantial. ${ }^{24}$ However, almost all of what we believe we know from this body of work relates to the US. To the extent that the legal and institutional frameworks, the level of statutory corporation tax, and the perceptions and behaviour of stakeholders are different in other country contexts, these established findings may or may not be applicable.

Second, we employ a broader set of tax payment measures, including both levels and changes over time, and also relative to sector averages than in any existing studies. Third, we consider the extent to which the tax-financial performance relationship may be affected by the nature of the firm's business (for example, whether it is directly customer facing or sells its products to other firms) and how it has changed over time. We believe that this research is particularly prescient given the increasing media attention given to tax-related scandals as described above, and perceptions both that tax avoidance activities are endemic among large multinationals and that stakeholders are increasingly unwilling to accept such behaviour. Fourth, we examine the link between tax payment and firm risk using both market and idiosyncratic risk measures. Finally, we investigate the impact of tax related news stories on company share prices using a larger, more comprehensive analysis than ever undertaken before, differentiating by type of news story and econometrically examining the factors that affect the size of the investor reaction. Importantly, we are the first to test and find revelations that a firm is engaged in tax avoidance activities does not affect its share price unless these activities relate to corporate inversions.

The remainder of this paper is structured as follows. Section 2 presents the existing scholarly evidence on the links between tax payment/avoidance and financial performance. Section 3 describes the data collection process and explains how the key variables are measured. Section 4 displays the main results on the extent to which these rates affect firms' financial performance. Finally, Section 5

\footnotetext{
${ }^{22}$ KPMG Annual survey of tax competitiveness, December 2013.

${ }^{23}$ P. Sikka, Big tax avoiders will easily get around new government policy, The Guardian, 15 February 2013.

${ }^{24}$ Hanlon and Heitzman (2010), for example, present a very comprehensive survey of the literature on many aspects of tax issues including the information content of tax reports, how tax affects corporate decision making, and tax avoidance. Unfortunately, the finance part of their paper is limited to a discussion of dividend and capital gains taxes rather than those specifically on corporate profits.
} 
examines whether tax-related media coverage affects the share prices of the firms concerned and Section 6 concludes and discusses the implications of our findings.

\section{The link between tax and financial performance: The existing evidence}

What are investors' views concerning the corporate tax debate, as revealed through their asset purchase and sale decisions, which feed into prices? Currently, there is very little direct evidence, and what research there is paints a mixed picture. One possible explanation of this lack of clarity is that some investors have a positive preference for tax avoidance to increase the firm's post-tax pay-outs, while others do not, and these effects will cancel each other out so that the net effect will be zero (Gallemore et al., 2014).

Although the responsible investment movement has grown enormously over the past two decades, both in terms of the numbers of funds and of assets under management, ${ }^{25}$ the vast majority of retail and institutional investors select their investments based predominantly or purely on narrower financial characteristics. Therefore, intuitively we might expect that shareholders would be in favour of the aggressive avoidance of tax to the maximum extent that is permissible within the law in order to enhance the post-tax profit levels available for distribution through dividends, share repurchases or for reinvestment in the business. It has been argued that tax is a cost like any other, and therefore company directors have a duty to their shareholders to minimise it through any legal means available. Shifting profits around the globe is then seen in the same light as switching utility suppliers. ${ }^{26}$

To some extent there are clientele effects at work in terms of the composition of shareholders and the link with corporate policies so that investors buy shares in companies having an ethos and a set of characteristics that they find appealing. In general, firms with a higher proportion of institutional investors (versus retail investors) are more tax aggressive. More specifically, firms whose shareholders are predominantly short term in their focus (e.g. hedge funds, private equity) are more likely to go for projects that will generate larger short-term earnings, possibly at the expense of longer-term profitability (Bushee, 2001). This translates to tax policies as well, so that firms backed by private equity (Badertscher et al., 2009) or where significant shareholders are hedge funds (Cheng et al., 2012) are more aggressive tax avoiders. By contrast firms with higher proportions of shareholders having long-term views (e.g. mutual or pension funds) have higher effective tax rates

\footnotetext{
${ }^{25}$ By way of illustration, there are now 1,260 organisations, accounting for more than US\$45 trillion in assets under management who are signatories to the United Nation's Principles for Responsible Investing - see www.unpri.org/viewer/?file=wp-content/uploads/2014_report_on_progress.pdf

${ }^{26}$ This view has been expressed in, for example, J. Riley, Is it wrong for a business to try to minimise how much tax it pays? The Great Business Debate, October 2014, www.greatbusinessdebate.co.uk/opinion/is-it-wrongfor-a-business-to-try-and-minimise-how-much-tax-it-pays
} 
(Khurana and Moser, 2013). Family-owned firms, on the other hand, exhibit lower degrees of tax avoidance (Chen et al., 2010) as a result of pride in the heritage of the firm and their emotional attachment to it, leading to heightened perceptions of reputational risk. On the other hand, privately owned non-family firms are more likely to avoid taxes since they can operate below the radar, facing less exposure than public firms (Cloyd et al., 1996).

Shareholders may react positively to news of tax avoidance activity if they view this as a signal of strong management committed to conserving the firm's resources and therefore to enhancing the value of their investment and, as a result, stock prices will be bid up. By contrast, if they believe that such behaviour may have negative consequences such as reputational damage or costly investigations from the tax authorities with the possibility of fines, interest and back payments, then prices will be pushed lower (Graham et al., 2013). Investors may also interpret this news as a sign of managerial incompetence in letting such dirty linen become publicly aired.

Firms that avoid tax are more likely to experience stock price crashes, although these effects are mitigated by strong governance and control (Kim et al., 2011). Similarly, the stock prices of well governed firms rise around the times when alleged tax avoidance by firms becomes public, indicating that this activity is positively viewed by investors in such firms (Wilson, 2009).

Using a sample of 108 US firms over the 1990 to 2004 period, Hanlon and Slemrod (2009) use an event study approach to investigate the impact on a company's share price of the revelation that they are involved in a tax sheltering activity. They find that returns during a three-day window around the news are $-0.5 \%$ for all firms, but becomes a more serious $-4.1 \%$ when they focus on the first major news story and the company is in the retail sector. The latter figure is both economically and statistically significant. They also observe, though, that the effect is muted for firms that simultaneously have high effective tax rates, which they interpret as implying that such firms are sensibly trying to reduce their taxes in a non-aggressive way. However, the Hanlon and Slemrod study examines only the very short-run impact of the news, and it is possible that this initial reaction is subsequently entirely reversed when the negative publicity blows over.

Shareholder reactions to the news that a firm is involved in a tax shelter seem to be much more modest than for other types of wrongdoings, but the vast majority of previous studies had focused on activities that were illegal - for example, price fixing (e.g. Garbade et al., 1982) or fraudulent misstatements of accounts (Dechow et al., 1996). A recent study by Choy et al. (2014) examined the effect of the ActionAid report discussed above on the share prices of the companies concerned. They find that within a two-day period on and after the announcement, there was an abnormal return of $0.87 \%$, which they calculate as equivalent to a fall in the combined market capitalisations of the affected firms of the order of half a billion pounds. 
Existing US studies appear to find mainly that tax expense 'surprises' (i.e. tax increases from one year to the next) are positively interpreted by shareholders as they signal improvements in the underlying profitability of the firm, and the markets react to this information with a lag (see Hanlon et al., 2005, Ohlson and Penman, 1992 using annual data, and Thomas and Zhang, 2011 using quarterly data). By contrast, there may be concern among investors that a fall in tax paid, even if underlying profit has risen, merely reflects an understatement of the firm's true liability in order to shift the burden from the present to the future by managers with short-term horizons and incentive structures; thus tax savings are believed to be temporary and will subsequently be reversed (see Lev and Nissim, 2004).

A particularly egregious form of tax avoidance is when firms engage in 'corporate expatriations' or 'inversions' as they are sometimes known. In some cases these involve a multinational company moving the domicile of the parent structure to a lower-tax jurisdiction (possibly a tax haven); in other examples, the firm goes as far as purchasing another company in a low-tax overseas location, which then effectively becomes the parent. For example, this is alleged to be the motivation behind Burger King's desire to buy the Canadian coffee shop Tim Hortons in $2014 .{ }^{27}$ Similarly, around 12 or 13 large UK-listed companies moved their domicile to Ireland in 2008, and the motive has been argued to be predominantly to reduce their tax bills (Voget, 2011). In theory, the tax saving will result from a reduction in a firm's tax liabilities on foreign earnings, but in practice a firm domiciled overseas may also find ways to transfer domestically earned income so that it originates in the tax haven and thus the firm's tax liabilities on domestic earnings also fall and this constitutes the bulk of the tax saving (Seida and Wempe, 2004).

Intuitively, we would expect shareholders to respond positively to announcements of such deals but the evidence suggests that this is not the case. Cloyd et al. (2003) examine the share price reactions around firms' announcements that they will expatriate to a tax haven. Of the, albeit small, sample of 19 such actions that they investigate, only two result in statistically significant positive returns while seven are significantly negative and the average return across all 19 is negative. They thus conclude that repatriations cannot consistently add to share prices and that the markets believe the appropriately discounted sum of the benefits does not outweigh the costs. Using a long window of two years before and after the inversion similarly shows no systematic pattern of positive returns. An interesting finding is that these expatriating firms typically have higher effective tax rates than comparators before the event, but these fall to industry-standard levels thereafter. In that sense, the corporate restructuring achieves its objective even if shareholders do not appreciate it.

Using a sample that is partially overlapping with that of Cloyd et al. (2003) but even smaller in number (12 companies), Seida and Wempe re-examine shareholder reactions to inversion announcements. They focus on a very short window of three days around the announcement and find

${ }^{27}$ See, for example, Aggressive tax avoidance troubles large investors, Financial Times, 2 November 2014. 
that average returns for inversion firms are around $2 \%$ greater than for a control sample, although this is not statistically significant. They demonstrate that, perhaps unsurprisingly, firms whose effective tax rates fall the most are subject to the greatest share price rises.

Almost all extant research presumes a linear relationship between tax avoidance and a market outcome (e.g. stock returns, the market-to-book ratio, or the cost of capital) but both intuition and financial theory (see, for example, Lambert et al., 2007) are suggestive that there may be declining returns to tax avoidance as the firm undertakes it to a greater extent. Thus at low levels of tax avoidance, firms can make savings in ways that are well within legal boundaries and unlikely to result in tax authority audits or bad publicity and thus increased tax avoidance will be correlated with a lower cost of capital. However, to further reduce their tax bills, firms that have already picked all of the 'low hanging fruit' must resort to more aggressive strategies that are closer to the margins of public (or even legal) acceptability and are therefore more likely to lead to regulatory scrutiny. Cook et al. (2013) find empirically that, indeed, the link between tax avoidance and the cost of capital varies in a convex non-linear way according to the degree of tax avoidance.

Although the presumption by most observers that engagement in tax avoidance would be at the behest of shareholders and in their best interest, a strand of the literature has argued that the principal-agent problem, where shareholders delegate responsibility for tax planning to managers within the organisation, may manifest itself in managers adopting aggressive tax strategies in order to increase their own remuneration (where bonuses are calculated on the basis of post-tax profits) and other nonpecuniary benefits. Brown et al. (2013) show that bonuses for CEOs and CFOs are higher for firms with lower effective tax rates. In such cases, any money saved through lower taxes does not find its way to shareholders (Garbarino, 2011; Desai and Dharmapala, 2006) but may nonetheless jeopardise the firm's reputation. Desai and Dharmapala note the importance of governance structures within the firm to limit this potential conflict. So firms may or may not follow the corporate tax strategies that their shareholders desire depending on the incentive structure that managers operate within (Slemrod, 2004). Overall, research is divided about whether, in pursuing their own interests, managers will avoid tax too aggressively or too tamely compared with what shareholders would ideally like.

Tax avoidance may benefit shareholders but the positives for debt holders, whose payments are fixed unless the firm defaults, are far less clear, and the number of studies examining this issue is very small. It is possible that a reduction in corporate tax payments will increase the ability of the firm to cover its interest payments, which will push up bond prices and drive down credit spreads. It is also possible that tax avoidance will reduce leverage (Graham and Tucker, 2006), and indeed tax avoiders appear to have lower levels of debt (Richardson et al., 2014) which implies reduced firm risk to the benefit of bond holders. But the empirical results show the opposite: firms avoiding tax to the greatest degree (the bottom quintile of firms by effective tax rate) exhibit lower credit ratings on their debts 
(Shevlin et al., 2013; Ayers et al., 2010; Crabtree and Maher, 2009). Based on an analysis of a large sample of US firms who took bank loans, Hasan et al. (2014) show that those engaging in tax avoidance to a greater extent are considered more risky entities by lenders, such that they face higher interest costs. Thus greater tax avoidance implies an increased cost of debt.

Much of the early research presumed that the sole objective of tax planning is the minimisation of effective tax rates. However, it is clear from recent reports discussed above from above that both managers and shareholders also value tax sustainability (defined, for example as the coefficient of variation of the cash ETR) as part of their tax strategy, even if this is at the expense of a higher average tax rate. Neuman et al. (2013) define tax risk as 'the potential that a chosen action or activity will lead to a tax outcome that is different than initially expected.' Tax risk has been proxied by the standard deviation of the firm's effective tax rate. Firms with low tax risk are typically large firms with higher proportions of intangible assets and low leverage compared with high tax risk firms. Guenther et al. (2013) define tax aggressiveness as engaging in a tax-related activity that uses ambiguity in the tax law and which is unlikely to survive a challenge by the authorities.

To what extent does a firm's tax risk affect the riskiness of its stock returns? This question is also investigated by Guenther et al. They observe a positive relationship between cash effective tax rates and tax risk, suggesting that a sub-set of firms is able to sustainably hold their tax rates down with low variation around a low mean, and these firms also have low stock return volatilities. However, they note that linking tax aggressiveness and shareholder outcomes is tricky since it may take a prolonged period (possibly many years) before any transgressions are detected and disputes are resolved. They conclude that tax policies only increase firm risk if they increase the uncertainty of its tax payments.

Neuman (2014) argues that one reason why different firms make different degrees of use of tax shelters is that their managers are incentivised differently. When CEO's income is sensitive to stock return volatility, the firm is more likely to focus on minimisation, whereas stability in corporate tax payments is more likely to be favoured when CEO's remuneration is more sensitive to changes in the firm's stock price.

Further developing this theme that both the average level of tax paid and its volatility (tax risk) are of concern to firms, Jacob and Schütt (2013) define a 'tax planning score' (TPS) measure, calculated as one minus the cash ETR divided by the standard deviation of the cash ETR. This measure thus allows for the possibility that firms achieving a low mean ETR might have a high volatility of ETR. They show that firms with good tax management (a high TPS) have higher market-to-book ratios, although they do not examine the impact on stock returns, which is arguably the variable of most direct interest to investors. 


\section{Data collection and organisation}

\subsection{Universe construction}

Our objective is to employ as cross-sectionally comprehensive and temporally extensive a sample of UK firms as possible. The stock universe is defined as all constituents of the FTSE All-Share Index between January 1988 and September 2014 that are neither Investment Trusts nor Real Estate Investment Trusts (REITs). The FTSE All-Share is a capitalisation-weighted index of all stocks traded on the main market of the London Stock Exchange (that is, excluding stocks listed on the Alternative Investment Market, AIM). The FTSE All-Share covers $98-99 \%$ of the whole UK market by capitalisation, and comprises all stocks that are part of the FTSE 100, FTSE 250 or FTSE Small Cap sub-indices. ${ }^{28}$ We exclude stocks quoted on AIM due to their relatively small capitalisations and illiquidity.

To be included in the sample, a stock must have been a member of the FTSE All-Share Index on the last day of each respective month. The constituents at each month end between January 1996 and September 2014 are obtained from the data provided by FTSE International Ltd on Thomson Datastream. In order to extend the sample backwards as far as possible, the composition of the FTSE All-Share Index for January 1988 to December 1995 is assembled from the annual report of constituents, name changes, inclusions and deletions published in the Journal of the Institute of Actuaries from 1988 to 1993, and in its successor, the British Actuarial Journal, for 1994 and $1995 .{ }^{29}$

\subsection{Return and accounts data}

Return and accounting data for the identified constituents of the FTSE All-Share Index are obtained from Compustat Global via Wharton Research Data Services (WRDS). Compustat Global includes both live and dead stocks, so that the sample is free from survivorship bias. When calculating monthly returns and market values, only share issues marked as common stock are included. Month-end market values and returns are calculated using the last available trading figures in each month. Monthend market values are calculated as: (No of shares in issue $\mathrm{x}$ Price Close Daily / 1,000,000), or in mnemonic terms:

$$
M V_{i, t}=\frac{\operatorname{prccd}_{i, t} \times \operatorname{cshoc}_{i, t}}{1,000,000}
$$

The end-of-month Return Factor for each stock is calculated as:

\footnotetext{
${ }^{28}$ See www.ftse.com/products/indices/uk. There are currently around 640 companies in the FTSE All-Share and thus our coverage is around $55 \%$ of the total.

${ }^{29}$ See www.actuaries.org.uk
} 
(Price Close Daily x Daily Total Return Factor / Cumulative Adjustment Factor (Issue) Ex-Date) to adjust prices for stock splits and dividends, following WRDS (2015) ${ }^{30}$ The raw monthly return for each company is then calculated as the proportionate increase in the month-end Return Factor, in mnemonic terms,

$$
r_{i, t}=\left(\frac{\left(\frac{\operatorname{prccd}_{i, t} \times t r f d_{i, t}}{a j e x d i_{i, t}}\right)}{\left(\frac{p r c c d i_{i, t-1} \times t r f d i_{i, t-1}}{\text { ajexdi }_{i, t-1}}\right)}-1\right)
$$

Monthly excess returns are then calculated over the pro-rated three-month UK Treasury Bill Tender Rate, obtained from Thomson Reuters Datastream. Where a company has two or more shares in issue at any one time, the aggregate market value represents the sum of the market value of each company's issues, and monthly returns represent the market-value weighted average of the returns of each of the issues. For each month, book-to-market is calculated as Book Equity / Market Value, where Book Equity is the value from the financial year ending at least six months previously, and Market Value is taken from the last trading day immediately prior to that financial year end. In mnemonic terms:

Book equity $_{\mathrm{it}} /$ market value $_{\mathrm{it}}=\left(\mathrm{ceq}_{\mathrm{it}}+\mathrm{txditc}_{\mathrm{it}}-\mathrm{pstk}_{\mathrm{it}}\right) /$ market value at prior year end

Industry affiliations are obtained by identifying the four-digit Industry Classification Benchmark (ICB) Subsector code for each company.

\subsection{Matching of return data with accounting information}

In the US asset pricing literature, the usual convention is to match monthly returns from July of year $t$ to June of year $t+1$ with accounts whose financial year ends are in December of year $t-1$, at the latest, to account for the delay between the financial year end and publication. Whereas most companies in the US have December financial year ends, many UK companies do not; in the present sample, December is not the financial year end for $52 \%$ of the sample, and $38 \%$ of the sample has a year end from January to June, as measured by aggregate firm-months. A methodology that adopted the US asset pricing convention on the present dataset would therefore have a sizeable minority of returns matched with accounts from financial years that ended at least 12 months previously, that is, whose accounting data would be at least a year out of date.

\footnotetext{
${ }^{30}$ See WRDS, Computing returns, Wharton Research Data Services Knowledge Base: Global (2015), http://wrds-

web.wharton.upenn.edu/wrds/support/Additional\%20Support/WRDS\%20Knowledge\%20Base\%20with\%20F AQs.cfm?article_id=5327\&folder_id=660
} 
To ensure that that most recent set of accounts are always used, the present sample matches the returns of each month with the most recent set of accounts whose financial year end is at least six months prior to the start of the month, on a rolling monthly basis. For example, a firm that has a financial year end of December will have the monthly returns of July of year $t$ to June of year $t+1$ matched with the accounts data for the financial year ending December of year $t-1$, while a firm having a financial year end in March (21\% of the present sample by firm-months) will have the monthly returns of October of year $t$ to September of year $t+1$ matched with the accounts data for the financial year ending March of year $t$. Short financial years therefore do not cause a coordination problem between financial data and stock returns in this study. All profit \& loss and cash flow items are normalised to 12-month equivalents using the length of the appropriate reporting period, in months, so that:

$$
\text { Current } P \& L \text { item }_{i, t}={\text { Reported } P \& L_{\text {item }}, t} \times 12 / \text { Reporting Period Length in months }_{i, t}
$$

This is to allow for valid comparisons across firms in the rare circumstances where the tax year is shorter than 12 months.

\subsection{Calculation of betas and idiosyncratic risk}

To calculate monthly market betas, we follow Fama and French $(1992 ; 1996)$ in estimating them on a rolling basis by regressing monthly excess stock returns above the risk-free rate against excess monthly market returns, using a minimum of 24 and a maximum of 60 prior monthly returns. For the market return, we use the proportional monthly increase in the Total Return Index of the FTSE AllShare Index, obtained from Thomson Reuters Datastream, and calculate excess returns over the prorated three-month UK Treasury Bill Tender Rate.

To calculate idiosyncratic volatility for each stock over the prior month, we follow Campbell et al. (2001) in regressing the daily excess returns of each stock above the risk-free rate against the daily excess returns of the market, and calculating the standard deviation of the residuals. As above, the Total Return of the FTSE All-Share Index is used as the market proxy, and the pro-rated daily value of the three-month UK Treasury Bill Tender Rate is used as the risk-free rate, both obtained from Thomson Reuters Datastream. We require a stock to have a minimum of ten valid daily returns in a month in order to calculate the idiosyncratic volatility for that month.

\subsection{Tax measures}

As discussed at length in the existing literature and summarised in Hanlon and Heitzman (2010) for example, there are numerous different ways in which the tax payment behaviour of firms can be captured. We employ as many of these as we are able to given available data and the context in which 
UK firms operate. We now present these approaches, explaining them in more detail in the subsequent discussion. In calculating mean values through time, for the single year tax calculations we drop any firm-years where the company has negative pre-tax profits from the sample since the calculation of effective tax rates in such cases would be problematic. When calculating five-year average figures, we retain individual firm years with negative pre-tax income provided that the corresponding five-year average is still positive.

We focus on standardised measures of tax expenses such as the effective tax rate to avoid the ambiguity in tax expense surprises in terms of the picture it paints of the underlying firm and whether it actually represents good or bad news. We can be clear that if an ETR rises, this means that the firm is paying a higher percentage of its gross profits in taxes, whereas if the firm's tax expense itself goes up, it might speak more to the strength of the firm's core business rather than relating to the quality or otherwise of its tax planning. All tax figures are normalised to 12-month equivalents using the same approach as described above for P\&L items.

1) Current effective tax rate (CETR), defined as

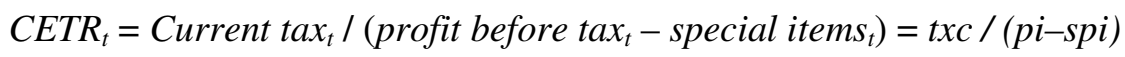

for each month, where the relevant accounting figures are the most recent accounts for each firm with a year end at least six months prior to the start of month $t$.

2) An alternative is what is termed in the literature the GAAP effective tax rate (GETR) that also incorporates deferred taxes, defined as:

GETR $_{t}=\left(\right.$ current tax $_{t}+$ deferred tax $) ~ /\left(\right.$ profit before tax $_{t}-$ special items $\left.s_{t}\right)$

3) The cash effective tax rate is also measured as a five-year rolling average to smooth the figures: ${ }^{31}$

$$
\text { CETR5 }_{t}=\frac{\sum_{i=t-4}^{t} \text { current tax }_{i}}{\sum_{i=t-4}^{t} \text { profit beforetax }_{i}-\sum_{i=t-4}^{t} \text { special items }_{i}}
$$

where the accounting figures are those that would have been available at $t, t-12, t-24, t-36$ and $t-48$ months, again assuming a six-month delay between the financial year end and publication. To be calculated, valid accounting figures must exist for each of the five years.

\footnotetext{
${ }^{31}$ A slight disadvantage of this approach is that as well as losing the first four years of the sample entirely, we also lose any firms that have fewer than five years of accounting data and thus it will imbue the results with a modest degree of survivorship bias.
} 
4) Similarly, it is possible to construct a total tax version of the five-year rolling average, GETR5:

$$
\text { GETR5 }_{t}=\frac{\sum_{i=t-4}^{t} \text { current tax }_{i}+\text { deferred tax }_{i}}{\sum_{i=t-4}^{t} \text { profit beforeta }_{i}-\sum_{i=t-4}^{t} \text { special items }_{i}}
$$

5) The book-tax difference (BTD) is:

$$
B T D_{t}=\frac{\text { book income }_{t}-\frac{\text { current tax }_{t}}{\text { statutory tax rate }_{t}}}{\text { total assets }_{t-1}}
$$

The statutory tax rate is taken as the rate that prevailed at the start of the month of the financial year end at time $t$, and book income is profit before tax in UK parlance.

6) The above is based on current taxes, so it is possible to instead use total tax to calculate the so-called permanent book-tax difference:

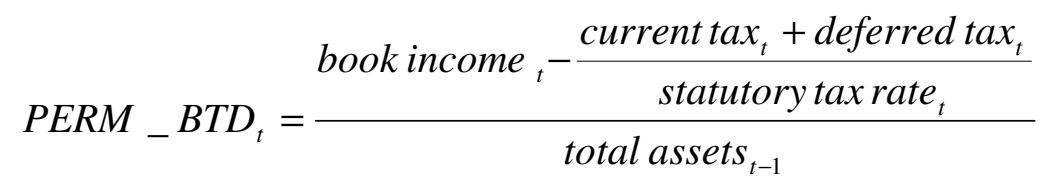

Again, the statutory tax rate is taken as the rate that prevailed at the start of the month of the financial year end at time $t$.

7) Tax-planning score (TPS) encompasses the fact that firms may be simultaneously targeting both low and stable tax rates. The tax planning score can be based on current tax:

TPS5_CETR $=(1-C E T R 5) / S D(C E T R 5)$

8) Or alternatively the tax planning score can be based on GAAP effective taxes:

$$
\text { TPS5_GETR }=(1-G E T R 5) / S D(G E T R 5)
$$

Where the tax planning score is one minus the effective tax rate over the past five years divided by the standard deviation of this effective tax rate within the five year period with CETR5 bounded at $(0,1)$, and analogously for GETR5.

9) $\triangle$ CETR is defined as the change in the cash effective tax rate between the most recently available tax figure as defined above and its previous value. 
10) $\triangle$ GETR is defined as the change in the GAAP effective tax rate between the most recently available tax figure as defined above and its previous value.

11) The difference between the CETR for firm $j$ and its industry average

12) The difference between the GETR for firm $j$ and its industry average

Before proceeding, some brief explanatory notes on the above tax measures are probably in order. A further measure of tax avoidance that has been widely applied in the US is based on 'unrecognised tax benefits', which are uncertain tax positions that can be stated under the 'FIN 48 ' rule. These reflect grey areas that are open to various interpretations such as transfer pricing agreements. Uncertain tax benefits may be thought of as management's assessment of 'more likely than not' (broadly $>50 \%$ ) economic outflow in the event of a successful tax authority challenge and can thus be used as a crude measure of the risk in a firm's tax planning. UK groups reporting under International Financial Reporting Standards (IFRS) are required to record comparable provisions based on judged probable economic outflow. Mechanics to calculate provision are different to US GAAP and no explicit disclosure is required under IFRS, but will still feature in CETR and GETR.

It has been suggested in the US literature that annual effective tax rates, especially in their current form, are too volatile to be of much practical use and could consequently potentially provide a misleading picture of how much tax a firm is paying. Dyreng et al. (2008) examine the extent to which firms in the US are able to reduce their effective tax rates. They find that while annual tax rates are persistent, there is considerable yearly variation and thus it is better to use ETRs calculated over a longer period such as five or even ten years. ${ }^{32}$ They also note that ETRs vary widely across firms from $19 \%$ to $37.2 \%$ and there is a substantial variation between firms within a given industry, perhaps indicating the considerable discretion that multinationals have to structure their activities to pay more or less tax as they desire.

We can think of effective tax rates as measuring the normalised amount of tax paid so that persistently lower rates than expected might signal tax avoidance. Book tax differences (BTDs), on the other hand, involve grossing up the current tax expense by the current statutory tax rate to estimate taxable income and then comparing this figure with the firm's actual income. So BTDs turn the measure on its head and a firm paying all the taxes due would have a BTD of zero with a positive figure suggesting tax avoidance and a negative figure suggesting overpayment. Book tax differences are positively correlated with the use of tax shelters, even after allowing for differences in firm characteristics between sheltering and non-sheltering firms (Wilson, 2009). In the US, managers may choose to report inflated earnings but a lower (uninflated) taxable income and recording a book tax difference in their financial statements. This should reduce tax liability but may damage the credibility

${ }^{32}$ See also Rego and Wilson (2012). 
of the reported earnings. The tax authorities may also use book tax differences as a way to select firms to further scrutinise and this practice may thus put them on the radar (Hanlon and Heitzman, 2010).

There are wide variations in tax rates across industries as a result of differing cost structures and differing levels of international exposures. As a result, investors are likely to compare the effective tax rate of a firm with its sectoral peers when forming judgements about the prudency or otherwise of the firm's tax policy, and thus it makes sense to also consider industry-adjusted effective tax rates. ${ }^{33}$

Following the standard approach in the literature beginning with Dyreng et al. (2008), the tax measures 1 to 4 above are winsorised at $(0,1)$, measures 9 and 10 are winsorised at $(-1,1)$ and all other variables are winsorised at the $1 \%$ and $99 \%$ levels to minimise the impacts of the most egregious outliers while retaining the vast bulk of the sample. Any firms making pre-tax losses are dropped from the sample for that year as the resulting negative ETRs would also distort the findings.

Much of the asset pricing literature begins from the premise that investors would be expected to require a premium for investing in a stock with exposure to unexpected changes in an endemic risk factor. Viewed in this way, one could suggest that the appropriate variable should not be a function of the level of tax avoidance but rather its change over time. This links with the view that news should drive stock returns, and where a firm simply reports the same tax level during two financial years, arguably no new information will have been revealed to the markets and therefore we might expect no price change and thus a return of zero. Hence, we also examine whether changes in the cash or GAAP effective tax rates, $\triangle$ CETR and $\triangle$ GETR respectively, have any explanatory power for the crosssectional variation in stock returns.

Table 1 begins by presenting summary statistics for the key variables including the number of data points $(\mathrm{N})$ available, their means, standard deviations and the 5th, 25th, 50th, 75th and 95th percentiles of the ordered distributions of the series. It is clear that both the effective tax measures are slightly skewed to the left, with the mean being greater than the median, while the book tax difference and the tax planning variables are all skewed to the right. There are on average 450 firms per year making a total of 10,729 firm-years - a sample comparable in size to those employed in existing studies of the US market. We present the summary statistics by industry using the ten ICB Subsector codes and also by firm size - split into the smallest 100 firms, the largest 100 firms and the remaining (medium-sized) firms. ${ }^{34}$

\footnotetext{
${ }^{33}$ We thank the anonymous referee for suggesting this.

${ }^{34}$ The number of firms in the telecoms and utilities sectors is fairly small and this needs to be borne in mind when interpreting the results, but the number of data points is credible for all other industries.
} 


\section{Testing the impact of effective tax rates on the cross- section of stock returns}

\subsection{Return-based regressions and the impact of effective tax rates}

In this sub-section we address the key question as to whether investors are concerned with the rates of corporation tax paid by the firms in which they own shares. If, for example, investors believe that taxavoiding firms are more likely to be the subject of an investigation by the tax authorities or the focus of negative media scrutiny or a consumer boycott, demand for the shares will be lower than for those of otherwise equivalent companies and investors will only be willing to hold them if they command a premium. Several existing studies (including Botosan, 1997 and Cook et al., 2013) examine the link between tax avoidance and the cost of capital that firms face. However, we argue that a focus on its effect on stock prices is more relevant for investors and hence is the subject of investigation here.

We tackle this issue in two ways - first, we run a set of panel regressions where a tax-related measure is an explanatory variable and the dependent variable is a set of firm-months' returns. This type of approach predominates in the accounting literature. In this case, Hausman tests indicate that the fixed effects are statistically significant and we therefore use a panel regression including industry dummies and time-fixed effects rather than random effects. Second, we employ a 'time series of cross-sections' approach of the form proposed by Fama and MacBeth (1973) and now widely employed in the asset pricing literature.

In both cases, the explanatory variables are motivated by the set used in studies by Fama and French (1992) and Carhart (1997): the CAPM measure of market risk (beta), the firm's book-to-market value ratio (BTM), the natural logarithm of market capitalisation (MV) as a measure of firm size, and the prior year's excess return for that firm $\left(\mathrm{R}_{\mathrm{i}, \mathrm{t}-1}\right)$ as a measure of the extent to which the firm's share price has momentum. We also include idiosyncratic risk (idio), which has been found in numerous studies to be a priced risk factor (and more important than beta in most cases) - see, for example, Bali et al. (2005); Bali and Cakici (2008); Li et al. (2009).

The reason that we include such variables in the regression is that it is a stylised fact in the finance literature that certain types of stocks yield, on average, considerably higher returns than others: small company stocks, value stocks (i.e. those with low price-to-earnings ratios or equivalently high earnings-to-price ratios); stocks that have high exposures to general movements in the market as a whole (i.e. those with high capital asset pricing model betas); and stocks with positive momentum (i.e. that have experienced recent price increases), have higher average returns than stocks with the opposite characteristics. When estimating the effects of tax variables, it is important to control for these characteristics to ensure that significant differences in returns caused by these variables are not 
spuriously attributed to low versus high taxes. For example, were a relatively high proportion of firms with high tax rates also value stocks with momentum, we would expect to observe higher returns among this subsample purely because of these non-tax stock characteristics. By including such standard risk factors in the model alongside the tax variable of interest in each case, we minimise the risk of misattributions of this kind.

The panel regressions are of the form:

$$
\begin{aligned}
R_{i, t} & =\alpha+\beta_{1} \text { Beta }_{i, t}+\beta_{2} M V_{i, t}+\beta_{3} \text { BTM }_{i, t}+\beta_{4} R_{i, t-1}+\beta_{5} \text { idio }_{i t}+\beta_{6} \operatorname{tax}_{i, t} \\
& +\gamma_{j} \text { industry dummies }_{i}+\delta_{k} \text { time dummies }_{t}+u_{i, t}
\end{aligned}
$$

where $R_{i t}$ is the excess return above the three-month Treasury Bill yield (a proxy for the risk-free rate of interest) for firm $i$ in month $t$, $\operatorname{tax}$ is the tax measure, and all other variables are as defined previously. However, to preserve space we only report the results from the Fama-MacBeth regressions and not the panel models. ${ }^{35}$

We adopt a variant on the 'time series of cross-sections' framework originally proposed by Fama and MacBeth (1973) and now very widely used in the finance literature. Following Fama and French (1992), Anderson and Brooks (2014), and Oikonomou et al. (2014) among many others, we implement the following procedure:

1) For each of the 286 months in the sample from December 1990 to September 2014 (or 272 months from February 1992 to September 2014 in the case of the five-year average CETR and GETR figures). The cross-sectional regressions are run separately for each tax measure with the monthly return on each stock $i$ as the dependent variable. ${ }^{36}$

2) For each given parameter, we then compute the average of the estimates over time, and calculate their standard errors.

3) We also employ the modification to the standard errors for the estimates on the intercept and the slope parameter on the CAPM beta due to Shanken (1992). This modification allows for the errors-in-variables problem arising from the use of estimated rather than actual values of

\footnotetext{
${ }^{35}$ We also employ the five-year averages for CETR and GETR but the results do not differ in any interesting way compared with those presented for the annual figures. This is perhaps not surprising given the statement in Guenther et al. (2013) that firms are able to sustain their tax policies over time and thus tax levels are not correlated with a risk that they will change. Therefore we do not present the CETR5 or GETR5 results to avoid repetition. In addition, since the tax planning variable was found above not to work well, we do not present the results from this in any of the subsequent analyses. As a robustness check, we also ran the regressions including as control variables all of the factors used to explain the tax payment/avoidance rates described above but again the results were not qualitatively altered and hence these regressions are not presented.

${ }^{36}$ Note that, following the procedures established in the existing literature, since these regressions do not include industry dummies (and they also do not include time dummies since they are cross-sectional) they instead include an intercept.
} 
the CAPM betas (which are unobservable) as explanatory variables in the cross-sectional regressions.

4) For each distinct system of monthly cross-sectional regressions, any stock that does not possess sufficient data to estimate any of the four models is not included in that month's cross-sectional regression. In this way, in each month, the number of stocks in each regression is the same for all of columns (1) to (4) in the tables of results so that they are based on the same samples and are therefore comparable. The average $\mathrm{R}^{2}$ in each case represents the timeseries average of the cross-sectional $\mathrm{R}^{2}$ values for each regression.

The results from the time series of cross-sections regressions are presented in Tables 2 to 9 respectively (CETR in Table 2, GETR in Table 3, BTD in Table 4, Permanent BTD in Table 5, $\triangle$ CETR in Table $6, \triangle$ GETR in Table 7 , and deviations of CETR and GETR from their industry averages in Tables 8 and 9). The difference in methodology between running separate cross-sectional regressions and then averaging them compared with a single-stage panel regression containing all observations would be expected to result in differences in the parameter estimates and possibly larger changes in their standard errors (and therefore the significance levels of the parameter estimates). ${ }^{37}$

Each column in the tables corresponds to a different set or sub-set of the explanatory variables, although the dependent variable is always monthly returns. So the model corresponding to the columns headed (1) include the standard four pricing factors (beta, market value, book-to-market ratio, prior year's excess returns) plus idiosyncratic risk; column (2) only includes the tax measure of interest with no control variables; column (3) includes the tax variable plus the standard four factors (i.e. excluding idiosyncratic risk); column (4) incorporates all of the variables, adding idiosyncratic risk to specification $(3) .^{38}$

The parameter estimates on the control variables in general accord with those in the existing and highly extensive literature in that stocks with relative price strength (i.e. momentum), value stocks, and stocks with high idiosyncratic risk, command higher returns. Interestingly, there is no small firm effect at work here - large firms on average command higher returns than otherwise similar small firms - confirming the results of other studies using UK data (e.g. Fama and French, 2012). In

\footnotetext{
${ }^{37}$ Effectively, the panel regression approach weights each firm-year observation equally within the entire sample whereas the time series of cross-sections approach weights each firm observation equally within a year, but this may imply different weights per stock across years. For example, in years where the number of firms in the sample is small, each firm's return will have a higher weight than in years where the number of firms is larger.

${ }^{38}$ Before proceeding to interpret the model estimates, we should note the considerable increase in the number of data points employed to over 100,000 now that monthly returns are used rather than annual data. An important implication of this is that the standard errors, which vary inversely with the sample size, are likely to be very small leading to a higher chance of statistical significance than would be the case with more modest numbers of observations.
} 
common with Agarwal and Taffler (2008), neither do the CAPM beta parameter estimates have the positive signs that orthodox theory would have predicted.

Turning now to focus on the tax variables, the common feature of all of Tables 2 to 9 is that none of the tax variables are remotely close to statistical significance at conventionally adopted levels in the regressions ${ }^{39}$ despite the large sample size, indicating that neither effective tax rates nor book tax differences are priced in stock returns. The only exception is the differences of the CETR from their industry averages in Table 8, where the tax variable is significant at the $10 \%$ or $5 \%$ levels, indicating that firms paying more than the average percentage of current tax in their industry yield higher returns, all else equal. However, even in this case the coefficients are of an economically trivial magnitude, suggesting that an increase by ten percentage points of the tax paid by firm $j$ relative to the average in its industry will result in a monthly return of around $0.04 \%$ higher, or an increase of $0.43 \%$ on an annualised basis. The inclusion of a tax measure in the return panel regressions typically adds a mere $1-2 \%$ to the adjusted $\mathrm{R}^{2}$, indicating a trivial increase in explanatory power. Thus, in sum, investors appear to be unconcerned with corporate taxes when making stock purchase and sale decisions, or alternatively it is possible that different groups of investors have specific preferences but on aggregate these are either inconsequential (swamped by the other factors they take into account) or they cancel each other out.

Although the lack of a significant relationship between tax and returns stands against the findings of Seida and Wempe (2004) following corporate inversions, these represent much more substantive oneoff changes in the firm's business structure than the year-to-year changes in effective tax rates and other measures that we examine here. Our results also contrast with those of Thomas and Zhang (2011) who observe a positive link between tax surprises and subsequent returns. However, they focus on nominal changes in tax payments rather than tax rates and while they orthogonalise the tax surprise with respect to changes in earnings, this will not entirely remove their effects if tax changes are a nonlinear function of profitability. As such, Thomas and Zhang may be picking up uncaptured postearnings announcement drift in their results.

\subsection{Does the relationship between tax and returns vary over time?}

As a robustness check, we repeat the analysis above but using a separate cross-sectional regression for each year for the CETR, GETR, $\triangle$ CETR and $\triangle$ GETR measures of effective tax rates. An examination of whether the nature of the tax-stock return link has changed is particularly relevant given the research by Klassen and Laplante (2012) suggesting that US firms moved more of their income

\footnotetext{
${ }^{39}$ The only exception is a very marginally significant (at the $10 \%$ level only) positive link between the GETR and stock returns in model (2) of Table 20, indicating that higher total tax payers yield higher returns for investors, but given the sheer number of different regressions we run, we dismiss this result as a statistical aberration.
} 
overseas in the 2005-09 period than previously against a backdrop of falling corporation tax rates in many other countries (including the UK). In our context, a declining statutory rate will necessarily have reduced the financial benefits of tax avoidance but probably not the costs as the issue has become increasingly politicised and the threat of negative publicity ever greater. We therefore postulate that, all else equal, the relationship between tax payment and stock returns has become more positive over time as tax avoiders suffer relatively lower returns.

For presentational brevity, we do not present the results but we find that high-tax paying firms command significantly higher returns in 1991, 1995, 2003, 2009 and 2010 and interestingly, low-tax paying firms only generate significantly higher returns in 1998. Firms which increased their tax rates by more than others experienced significantly lower stock returns in 1993 and 2001 but significantly higher returns in 2002 and 2003. We therefore conclude that these fleeting instances of statistical significance are false positives and that the above conclusion regarding the lack of link between stock returns and tax payments holds throughout the sample period.

\subsection{Does the relationship between tax and returns vary by industry?}

A key reason cited in the literature as to why firms do not make more widespread use of tax avoidance measures is that they are concerned about possible reputational fallout if this activity becomes the subject of negative publicity in the media. For example, a survey of senior managers by Graham et al. (2013) indicated that two-thirds regarded reputational damage as a reason not to adopt a tax planning strategy. ${ }^{40}$ Although this does not necessarily mean that other stakeholder groups, and especially investors, would be equally concerned, it raises two important questions: first, are reputations affected in this way, and second, when details of the firm's tax avoidance activities become public, does this affect the firm financially?

Intuitively, we would expect that firms with the most highly valued brands or those with the strongest reputations would potentially have more to lose and would therefore be less likely to engage in tax avoidance. These firms are also more likely to be in the public eye, and any stories about their behaviour will be more newsworthy than those involving less well known brands. As discussed above, we would also expect that firms bidding for large central government contracts are required to have been free from outward signs of tax avoidance for the previous decade, and they should also be less likely to engage in it. Austin and Wilson (2013) are not able to uncover a link between brand value and a higher incidence of shunning tax avoidance within a sample of highly valued consumer brands. However, they do find that firms possessing one or more valuable brands pay higher effective tax rates than otherwise identical firms owning no such brands.

\footnotetext{
${ }^{40}$ Relatedly, a recent survey by EY found a $72 \%$ increase in the number of companies who are concerned about media coverage of taxes since 2011.
} 
One way that consumers can express their displeasure at the actions of a firm is through a boycott, and these can be either organised or individual. Consumers may do this as a last resort when they feel that they do not have the franchise to affect the firm's behaviour or processes in any other fashion, as firms are seen as becoming larger, more formalised, increasingly dehumanised and less approachable. A poll involving over 15,000 participants from 17 countries revealed that more than a third had boycotted at least one brand according to an article in the Guardian. ${ }^{41}$ The success of boycotts from the perspective of those engaging in them can be judged in two ways: first, did the action help to bring about a change in the firm's business practices; and second, was the firm 'punished' for its actions even if these continued? Only the second is of direct relevance to our study, and the evidence is mixed and based mostly on very small samples but broadly suggestive that boycotts do not hurt the firm financially. This contradicts earlier results by Pruitt and Friedman (1986) showing that boycotts led to substantial financial losses for $76 \%$ of firms in their sample. However, it may be the case that consumers are more likely to boycott a firm in response to an issue they feel more strongly about than $\operatorname{tax}$.

Both actual boycotts and threats of boycotts actually engendered rises in the share prices of the firms concerned by around $0.7 \%$ on the day that the news of the boycott (or threat) became public according to a study by Koku et al. (1997). They attribute this finding to the power of the "damage limitation machines' that firms typically employ concurrently to mitigate any adverse publicity, for example by mounting advertising campaigns or engaging in philanthropic activities. Firms facing allegations that they pay insufficient tax are often seen to increase their own marketing rhetoric (see Hale et al., 2005), for example by pointing out their numerous positive economic impacts through employment, as well as noting the range of other taxes that they pay or collect including employment and sales taxes. In the area of reputational recovery and damage control, Van Hoye and Lievens (2005) show that adverse publicity can be mitigated by recruitment advertising and by positive word-of-mouth. ${ }^{42}$

Popular belief and discussion in the existing literature discussed above suggest that any negative perceptions of tax avoidance may be more strongly felt in companies that are directly end-customer facing (especially retailers) than in firms which sell to other businesses. In order to test whether this affects stock market performance, we also conduct separate analysis for each of the ten sector classifications in our sample. The results from the analysis by industry are not presented, but we observe that there is a positive and moderately significant (at the 5\% level) link between CETR / $\triangle$ CETR and stock returns for the financial services sector (firms paying higher taxes generate higher stock returns) but a negative link between changes in CETR / GETR and returns in the technology

\footnotetext{
${ }^{41}$ See www.theguardian.com/business/businessinsight/2005/sep/01/branded1

${ }^{42}$ Relatedly, Williams and Barrett (2000), for example, show that philanthropic giving can mitigate the negative effects of revelations that a firm is engaged in criminal activity.
} 
sector (so firms that increased their tax bills the most from one year to the next on average generated the lowest stock returns).

However, as above, there very are few salient features to report from these numbers, and in particular the link between tax payment / avoidance and stock returns is not stronger for consumer services than for the equity universe as a whole. The lack of a strong relationship between the firm's line of business and shareholders' reactions to its level of tax payment/avoidance corroborates the mixed findings in Austin and Wilson (2013) for the US. Gallemore et al. (2014) are unable to substantiate any link even between firm reputation and tax sheltering, so the link between investor preferences and tax sheltering is arguably a further step removed and thus the lack of significant results is perhaps unsurprising. Overall, the lack of a solid link between a firm's stock market performance and variables that capture corporate taxes is entirely consistent with the US-based evidence where different studies have found either positive (e.g. Wilson, 2009) or negative (e.g. Desai and Dharmapala, 2009; Hanlon and Slemrod, 2009) links dependent upon the precise measures of tax and of financial performance / valuation.

\subsection{Are firms that have lower effective tax rates more risky?}

Recent (US-based) studies (e.g. Guenther et al., 2013) have suggested that tax avoidance is a risky activity that will be reflected in the variability of share prices over time. Tables 10 and 11 investigate this proposition directly using the two most popular measures of firm risk originating from the stock market: the CAPM beta (Table 10) and idiosyncratic risk (Table 11). In stark contrast to the results from the return-based regressions, however tax payment / avoidance is measured, firms with lower rates of effective corporate tax (higher book tax differences) have significantly (at the $1 \%$ level) higher betas, indicating that their stock is more risky, with the prices of those stocks on average moving in the same direction as the market as a whole but with amplified movements.

The results from the idiosyncratic risk measure (Table 10) are slightly less uniform but nonetheless show that lower effective tax rates go hand-in-hand with higher stock price risk. For the cash effective tax rate, the five-year average GAAP effective tax rate, and the book tax difference (in both its current and GAAP forms), the coefficients have the expected signs and are significant at the $0.1 \%$ level. This result is in line with the conclusions of Hasan et al. (2014) whereby firms which engage in tax avoidance to a greater extent face higher interest charges on bank loans consistent with a perception that they are more risky. We contribute to this finding by showing that such firms have higher equity, as well as loan-related, risk.

Our findings confirm the negative sign in the link between CETR and stock return volatility presented in Guenther et al. (2013) based on US data, although the results are much stronger in our case in that 
they are highly statistically significant and we confirm that this conclusion is robust using a range of other tax measures.

It is beyond the scope of the present study to identify the cause of increased risk among lower-tax payers (after controlling for industry effects and other stock-specific characteristics), but there are many channels through which tax avoidance may increase risk to the firm and which may then be reflected in heightened stock return risk. First, tax aggressiveness may lead to doubts about the informativeness of other aspects of the firm's accounts (Desai et al., 2006). In other words, it could increase 'information risk', as tax avoidance engenders greater complexity in the organisational structure of the business (Desai and Dharmapala, 2006) and 'enhances the manager's ability to mask, justify and hide bad news for extended periods' (Hasan et al., 2014, p. 112). Second, firms that avoid tax aggressively are more likely to face an audit by the tax authorities (Mills, 1998), which would, as shown below, probably result in share price falls. Third, tax avoidance is linked with increased tendencies for managers to misappropriate resources from activities that would maximise shareholder value, thus heightening so-called 'agency risk' (Desai and Dharmapala, 2006). It may be that the managers of tax-avoiding firms are incentivised to simultaneously take greater risks in the activities of the firms they run or the instruments used to finance it and to reduce its corporate tax bills (see Neuman, 2014 or Rego and Wilson, 2012).

\section{Does tax-related media coverage affect share prices?}

What are the reputational effects for those firms whose tax avoidance activities have become newsworthy? This is the focus of a paper by Gallemore et al. (2014) who find a negative stock price reaction at the time of the publicity, but this is relatively short lived, so that within a month following the media attention, the price recovers to its prior level. They also find that tax avoidance revelations do not result in heightened CEO, CFO or auditor turnover compared with a sample of otherwise identical firms. Similarly, there is no discernible relative impact on sales growth or advertising expenses, and no change in the likelihood that the firm will be present in the Fortune 'World's Most Admired Companies' list. Thus, according to this study, it appears that the impact of being labelled in the media as an aggressive tax avoider has very little permanent impact, either reputationally or financially, on the firm. This contrasts starkly with the effects of negative publicity surrounding a firm's wrongdoings of an illegal nature, where the reputational and financial effects can be quite severe (see, for example, Dechow et al., 1996 or Karpoff et al., 2008a and 2008b for discussions of the consequences of accounting irregularities and frauds). Furthermore, Gallemore et al. (2014) also note that the effective tax rates for such firms do not rise noticeably after the revelations, suggesting that these firms are not sufficiently concerned to change their behaviour. Thus it appears from their study that tax avoidance is not regarded as a serious corporate misdeed after all. 


\subsection{Finding tax stories in the news}

While we do not uncover any link between measures of corporation tax paid or avoided, it may be that the tax affairs of firms that can avoid tax but where such activities remain undetected are not of concern to investors. It might be more fruitful to focus only on those firms that experience media attention regarding their tax payments (or more plausibly the lack thereof). It is unlikely that consumers can reveal a distaste for tax avoidance in their purchasing decisions unless this information has become widely available through the media. As such, it is of interest to gauge the reaction of shareholders to such news since, if the information is available to investors, the firm's customers and suppliers will probably also have become aware of the misdemeanour. In the absence of media attention, tax avoidance activities may remain outside consumers' information sets and therefore have a more positive impact on stock price valuations. Existing work in this area is very sparse and virtually non-existent outside the US. Gallemore et al. (2014) conduct a very limited analysis of shareholder reactions to a media revelation that a firm is involved in tax sheltering activities using a three-day event window, finding a very modest effect that is fully reversed within a few weeks.

We perform a search for news items over the January 1991 - October 2014 period $^{43}$ where the name of a specific firm is linked with corporation tax using the search terms 'tax shelter(s)/sheltering', 'tax avoid(ance)', 'tax haven(s)', 'tax evasion/evade tax(es)', 'tax exile(s)', 'tax + fine(s)', 'tax + investigation(s)', 'tax + lawsuit', and 'tax + HMRC' using the Factiva database.

The initial searches are conducted in a batch but each hit is followed by a manual investigation to determine the nature and relevance of the news story. We ignore general articles about tax avoidance where no actual company names are mentioned so that to be included in our analysis a story has to relate to a direct event or an accusation of tax avoidance regarding specific a company or companies. We also ignore news relating to financial institutions that 'offer tax avoidance schemes to clients' and any instances where specific people are accused of tax avoidance since the focus is on corporate rather than individual activities. The search includes all national and major regional UK newspapers as well as major international and on-line sources and specialist financial outlets. Defined in this way, the sample includes news stories on $N=237$ separate firms that were constituents of the FTSE AllShare Index at that point in time. Our sample thus covers a longer period and incorporates a considerably larger number of firms than that employed in any comparable existing study.

\footnotetext{
${ }^{43}$ In fact, the first news story uncovered is on 19 April 1991 and the last is 17 October 2014.
} 


\subsection{The event study approach}

We adopt an event study methodology, ${ }^{44}$ investigating abnormal share price movements and relating these to the news stories using a 61 trading-day window (approximately three calendar months) from -30 to +30 , where 0 is the date on which the news story appears. We only include in the database the first news story that appears since, arguably, any subsequent news stories over the next few days do not reveal any new knowledge to the market and are merely repeating stale information. We are careful to remove any news stories where there are any potentially negative confounding events occurring within a one-week period prior to the event day to ensure that any tax effects on share prices that we observe are 'clean'.

Expected returns are defined using the CAPM beta estimated using daily data over the 220-day period immediately before the start of the event window (i.e. from T-250 to T-31). We thus require that each stock entering the sample has a stock trading history at least this long and this results in us losing an additional handful of observations from the initial sample of $237 .^{45}$

For each news event, a market model is estimated:

$$
R_{i, t}=\alpha_{i}+\beta_{i} R_{m, t}+\varepsilon_{i, t}
$$

where: $R_{i, t}$ is the proportional daily return of stock $i$ over the risk-free rate on day $t, R_{m, t}$ is the proportional daily return of the FTSE All-Share Index as proxy for the market, over the risk-free rate on day $t, \alpha_{i}$ is the alpha of stock $i$, and $\beta_{i}$ is the beta of stock $i$. Following MacKinlay (1997), the saved parameters from the estimation period are then used to calculate daily abnormal returns (AR) over the event window as:

$$
A R_{i, \tau}=R_{i, \tau}-\left(\hat{\alpha}_{i}+\hat{\beta}_{i} R_{m, \tau}\right)
$$

The average cross-sectional daily abnormal excess returns across all $N$ events for each day in event time are calculated as:

$$
\overline{A R}_{\tau}=\frac{1}{N} \sum_{i=1}^{N} A R_{i, \tau}
$$

The cross-sectional variance of daily abnormal excess returns is given by:

\footnotetext{
${ }^{44}$ See Brooks (2014, section 14.9) for an introductory guide to event studies; further detail is given in the survey papers by Armitage (1995) and MacKinlay (1997).

${ }^{45}$ In order to minimise the effects of confounding but irrelevant events and following standard practice, we winsorise the abnormal returns at 5\% and 95\%. Cowan and Sergeant (2001) find that buy-and-hold abnormal portfolio returns in event studies tend to be heavily positively skewed, leading to the lower tail null hypothesis being rejected at ten times the rate of the upper tail null in randomised samples. They therefore suggest the winsorisation of abnormal returns in event studies in order to produce a more correctly specified and powerful test statistic, since this tends to preferentially truncate the upper tail of the distribution.
} 


$$
\operatorname{Var}\left(\overline{A R}_{\tau}\right)=\frac{1}{N^{2}} \sum_{i=1}^{N} \sigma_{\varepsilon_{i}}^{2}
$$

and the $t$-ratio of the average cross-sectional abnormal excess returns is: $\frac{\overline{A R}_{\tau}}{\sqrt{\operatorname{Var}\left(\overline{A R}_{\tau}\right)}}$.

Cumulative abnormal returns (CARs) between $\tau_{1}$ and $\tau_{2}$ are calculated from:

$$
\overline{\operatorname{CAR}}_{\left(\tau_{1}, \tau_{2}\right)}=\sum_{\tau=\tau_{1}}^{\tau_{2}} \overline{A R}_{\tau}
$$

and the variance of the cumulative abnormal daily returns as:

$$
\operatorname{Var}\left(\overline{\operatorname{CAR}}_{\left(\tau_{1}, \tau_{2}\right)}\right)=\sum_{\tau=\tau_{1}}^{\tau_{2}} \operatorname{Var}\left(\overline{A R}_{\tau}\right)
$$

Finally, the $t$-ratio of the cumulative abnormal daily returns is then: $\frac{\overline{C A R}_{\left(\tau_{1}, \tau_{2}\right)}}{\sqrt{\operatorname{Var}\left(\overline{C A R}_{\left(\tau_{1}, \tau_{2}\right)}\right)}}$.

For presentational purposes, we measure cumulative abnormal returns from $\mathrm{T}-30$ to $-10 ;-10$ to -1 ; day $0 ;+1$ to +10 ; and +10 to +30 . For comparison with the single existing study by Hanlon and Slemrod (2009), we also present results for the narrower seven-day event window -3 to +3 . Statistical significance is measured using t-ratios calculated from the cross-sectional standard deviations of the abnormal returns or cumulative abnormal returns on the day or days under study.

\subsection{Tax news effects on trading volumes}

In addition to examining the relationship between press coverage and stock returns, we consider whether such news stories also affect trading volumes, which allows us to investigate our conjecture above that there may be clientele effects at work whereby some investors are deeply concerned by tax avoidance while others value it provided that it adds to net profits. In this way, we can see whether the buying and selling behaviour of these two groups of investors increases volumes but in an offsetting way so that prices are largely unaffected, which would be consistent with our finding above that effective tax rates do not affect returns when considering all firms together. ${ }^{46}$ Following Kappou et al. (2008), Harris and Gurel (1986) and Beneish and Whaley (1996), we first select only those news items which represent the first mention of a news story. Next, for each event, we calculate the average stock-to-FTSE All-Share turnover ratio over a period of 60 trading days before the event window, as:

\footnotetext{
${ }^{46}$ We thank the anonymous referee for suggesting this line of enquiry.
} 


$$
\overline{B V R}_{i}=\frac{1}{60} \sum_{\tau=t-65}^{\tau=t-5}\left(\frac{V_{i, \tau}}{V_{m, \tau}}\right)
$$

where $V_{\mathrm{i},} \tau$ is the proportional turnover of stock $i$ on day $\tau$, and $V_{\mathrm{i},} \tau$ is the mean proportional turnover of all FTSE All-Share constituent stocks on day $\tau$, where $\tau$ denotes a time point in the observation period. Next, for each stock, we calculate the volume ratio for each news event between $t \mathrm{~T}-5$ and $\mathrm{T}+60$ days, as:

$$
V R_{i t}=\frac{V_{i, \tau} / V_{m, \tau}}{\overline{B V R}_{i}}
$$

For each day $\tau$ in event time, we winsorize $V R_{\mathrm{i},} \tau$ at the $1 \%$ and $99 \%$ fractiles to remove the influence of outliers. Finally, for each day in event time between T-5 and T +60 days, we calculate the Mean Volume Ratio across all $N$ stocks in the sample, as

$$
M V R_{\tau}=\frac{1}{N} \sum_{i=1}^{N} V R_{i, \tau}
$$

\subsection{Tax news stories and returns: results and analysis}

Our presumption is that such news reports will be negatively viewed by investors and therefore demand for the shares and share prices will fall around the date of the appearance of the news story (before if there is leakage of the news, or after if there is a delayed reaction). A negative abnormal return might be expected for various reasons as discussed above: the firm's costs may increase if they are subject to back-payment requirements, fines or interest penalties, and revenues may fall if disaffected customers take their business elsewhere. The news may also be viewed by investors as a signal of managerial incompetence in letting such stories become public in the first place (Bosch and Eckard, 1991).

The results are presented in Table 12, with those for the entire sample of firms subject to news stories in the second column. As can be seen, the cumulative abnormal returns are negative for the entire preevent period (for both $\mathrm{T}-30$ to $\mathrm{T}-10$ and $\mathrm{T}-10$ to $\mathrm{T}-1$ ), and on the event day itself, suggesting that revelations regarding a firm being involved in tax avoidance are viewed somewhat negatively, although the magnitudes are very small and none are statistically significant even at the $10 \%$ level. There is a modest reversal in the following days, however, as cumulative abnormal returns are a positive, albeit not significant $0.6 \%$ for the two-trading week period following the news story, and remain positive albeit very small in magnitude and not significant thereafter until the end of the event window. 
To better enable the reader to visualise the results, the CARs from day -30 to +30 are plotted for all firms in Figure 1. It is clear that risk-adjusted returns are negative from around day -22 to +30 . Very little happens immediately around the event day, perhaps because in many cases the relevant information was already in the public domain or at least known among those who work in the investment or tax communities. By around a week after the day that the news story appears, the CAR rises from $-1.2 \%$ to end at $-0.6 \%$. The latter may result from the positive effects on share prices that arise from any kind of news (both good and bad) in putting the stock 'on the radar' of prospective purchasers. In that sense, any news is good news as it increases demand for the firm's shares, especially among retail investors (Barber and Odean, 2008). The subsequent partial recovery of share prices is also consistent with the finding of Koku et al. (1997) regarding the superficially perverse positive effects of consumer boycotts of the firm's products on its stock price, which they argue may arise as a result of heightened public relations efforts by those firms affected, which more than cancel out the effects of the bad publicity. More broadly, in any situation where a company's product or service is relatively unknown, any publicity can be good, even if it is negative. For example, Berger et al. (2010) show that negative reviews can increase the sales of previously unfamiliar books as the awareness-raising effect more than offsets the negative sentiment of the information.

While the findings for news stories involving all firms show muted effects, it is possible that such publicity has larger impacts for some types of firms than others. To investigate this, the total sample of 237 firms is split into sub-samples along various dimensions. First, it might be the case that taxrelated news stories have a larger effect on the share prices of small firms since they are the subject of much less other coverage. For large firms, on the other hand, the effects of any negative tax-related stories may be washed out among a general fog of other news items occurring on a daily or even hourly basis. We therefore construct a big/small dummy variable that takes the value one if the company was in the top 175 companies as ranked by market capitalisation in the overall sample of UK stocks at the start of the month in which the news item occurred, and zero otherwise. ${ }^{47}$

Although the sample is very unbalanced (as one might expect) in that large firms have eight times more tax-related stories, the impact on small firms is considerably stronger. On average, the share prices of small firms fall by a risk-adjusted $7 \%$ in the -25 to +5 window and by a further $2 \%$ the two weeks before the story and $1 \%$ on the event day. However, the subsequent bounce back in the share price is also stronger at $0.6 \%$ during +1 to +10 and an additional $0.5 \%$ thereafter. Both the initial falls in share prices and the subsequent recovery are both more muted for large firms, which is consistent with the notion that small firms are starved of attention and hence a given amount of additional coverage will have a magnified effect.

\footnotetext{
${ }^{47}$ Unlike the earlier analysis, since the number of news stories is relatively small, we define firms as either large or small, they cannot be medium sized.
} 
Figure 2 clearly shows markedly different profiles of cumulative abnormal returns for small versus big firms. In the latter case, abnormal returns are negative but close to zero for the four trading weeks prior to the news story and then there is a gradual recovery and eventually cumulative returns end at around zero four weeks after the news. By contrast, CARs for small firms fall almost monotonically from zero at day -22 to a substantial $-7 \%$ by day +5 .

Our second sample split is motivated by the plausible expectation that news stories will engender greater shareholder reactions when they reveal more serious misdeeds that could affect a firm's profitability directly. For example, increased tax avoidance might bring with it increased risks of penalty and back-payment demands, as well as of interest costs from the tax authorities if the firm is caught and punished. Following the Cloyd et al. (2003) work for the US, we also specifically separate out news stories that a firm is or may be involved in an expatriation (corporate inversion).

To capture these potentially serious misdeeds, we focus on the search terms 'tax shelter(s)/sheltering' ,'tax + fine(s)', 'tax + investigation(s)', 'tax + lawsuit', and 'tax + HMRC' and there are a total of 94 firms listed within such stories. These results are presented in the fifth column of Table 12 headed 'potentially culpable stories' with the remaining stories gathered into a sub-sample analysed in column six ('general stories'). The more serious issues, where the news items may relate to wrongdoing of a nature unacceptable to HMRC, result in a $0.8 \%$ negative abnormal return (although still statistically insignificant) in the $(-30,-10)$ period, and further negative returns up to and including the event day. The cumulative return totals $-1.3 \%$ by the end of the event day from $\mathrm{T}-30$. Although the eventual rebound for firms reported in potentially culpable stories is slightly stronger in the longer term than is the case for firms where the stories are weaker, it is clear overall that investors do view these in a more negative light than less serious news stories as one might anticipate.

Figure 3 shows that for the potentially culpable sub-sample, the CAR is negative from soon after the beginning of the event window at $\mathrm{T}-25$ through to around $\mathrm{T}-15$ (perhaps because of leakage or the information already being known by insiders) when it falls to its lowest point of $-1.4 \%$. The share prices of such companies typically remain in the doldrums for a further month after the story breaks and thereafter there is a recovery so that share prices end the event window very slightly below the level at which they started.

There is very little existing research against which we can sense-check our findings. However, Dhaliwal and Erickson (1998) demonstrate that stock prices show a reaction to the announcements of the decisions of tax courts in the US. Similarly, Dyreng et al. (2014) and Choy et al. (2014) find that firms that had not disclosed all of their foreign subsidiary locations as the (unenforced) law in theory requires were subject to market-adjusted abnormal returns averaging $-1 \%$ in the three-day period around when the ActionAid report was published on 11 October 2011, as described earlier in this 
report. Although it is possible that there was a subsequent reversal, the studies do not consider a longer event window and so this remains untested.

By contrast, our results in Table 12 and Figure 3 show that stories of a more trivial nature have very little effect on the share price with an initial fall of $0.8 \%$ from $\mathrm{T}-30$ to $\mathrm{T}-10$ but then a rise of $0.5 \%$ from $\mathrm{T}-10$ to $\mathrm{T}-1$ followed by a fall again of $0.2 \%$ on the event day, a $0.3 \%$ fall to $\mathrm{T}+10$ and then a partial recovery. Overall, the substantial variation and lack of a consistent directional pattern is perhaps because the attention effect of being reported counterbalances any negative sentiment about tax avoidance. It is also possible that any negative effects from potential bad news stories are already priced into the shares at the time that any perceived poor practice is picked up in the media so that 'naming and shaming' such firms has no noticeable effect on their stock prices.

Our news database search also reveals 27 separate first stories where companies were involved in an inversion (expatriation), whereby there was a move or a proposed move to switch the headquarters of the company and its official jurisdiction to another country primarily to reduce its corporation tax bill. As Table 12 and Figure 3 show, such news is typically very badly received, with almost a monotonic daily fall in share price from $\mathrm{T}-23$ to $\mathrm{T}+4$ and then some variation in price but no overall trend until the end; overall, though, the price is on average three percentage points lower than it started the event window. This strong negative view of expatriations ('corporate desertions' as President Obama termed them), confirms the findings of Cloyd et al. (2003) for the US. However, we should note that inversions often involve the takeover of a firm in the low tax country which then becomes the parent, and thus the negative inversion reaction may actually be a manifestation of the standard negative takeover reaction for the acquirer. It may also relate to heightened uncertainties and fears regarding relocation costs. In the present sample, all of the inversion stories relate to existing UK companies shifting existing head office functions abroad, rather than mounting a takeover of a foreign firm in a low tax jurisdiction, so that the stock price reaction can be attributed solely to the investor response to the news of the inversion.

Third, we further split the sample according to the type of newspaper outlet covering the story viz. large regional/local versus national or international newspapers, with the latter being further separated into specialist financial newspapers (e.g., the Financial Times, City AM, The Sunday Business Post) in columns 7 to 10 of Table 12, although no strong findings emerge.

Fourth, we separate firms based on their line of business into consumer-facing and non-consumerfacing companies. The consumer-facing dummy takes the value one if the company has an ICB Industry Subsector code from 3000 to 3999 (Consumer Goods) or 5000 to 5999 (Consumer Services), and zero otherwise. As discussed above, end consumers may be less forgiving of perceived corporate transgressions than is the case when the firm sells to other firms. As a result, when, for example, retailers or banks are involved in a tax-avoidance scandal, they may be subject to a boycott that could 
potentially reduce sales and damage relationships with customers and workers. According to the numbers reported in Table 12, consumer-facing firms suffer negative abnormal returns from $\mathrm{T}-30$ right through to the event day, although they are most extreme at $-1.3 \%$ from day -30 to -10 . Such companies do, however, show a stronger rebound in the immediate post-news period than their business-to-business counterparts, as shown in Figure 4. Overall, by six trading weeks after the first story broke, non-consumer facing firms' share prices are at almost the same level as they were six trading weeks before the news, while those of consumer-facing firms have fallen by almost $2 \%$

Turning now to our results on the analysis of volume ratios, Table 13 presents these for each day during a shorter event window (T-3 to $\mathrm{T}+10),{ }^{48}$ and shows some fascinating patterns. First, for all the sub-samples the volume ratios (which have a 'natural' level of unity by construction) rise noticeably a couple of days before the event and remain discernibly high until around four days afterwards. The second columns after the volume ratios in each case present the t-ratios of tests of the null hypothesis that the volume ratios are one. For the entire sample (columns 2 and 3), the volume ratios reach a peak of 1.2 on the event day and are statistically significantly different from unity. They remain significantly above one until day $\mathrm{T}+4$, except for $\mathrm{T}+1$; they also pick up again from $\mathrm{T}+8$ to $\mathrm{T}+10$. For small firms, the volume ratios are even higher around the event day (and much larger than for the large firm sub-sample), although they are mostly not statistically significant. ${ }^{49}$ Similarly, the volume ratios are much higher for the culpable sub-sample than the non-culpable (general stories), again peaking on days $\mathrm{T}-3$ to $\mathrm{T}$ ), and they are higher still for the expatriations sub-sample, where they reach a peak at 1.8 on the event day. Figures 5 and 6 further emphasise these patterns, showing that for the small firm and expatriation sub-samples, and to a lesser extent for the culpable firms, trading volumes are heightened throughout the event window and have not died down to their pre-news levels even after two weeks. Altogether, the volume results are highly plausible and indicate that trading activity is heightened around tax-related news announcements, with some leakage a few days before the event and giving credence to our suggestion that the investment clientele of firms may be changing as a result of these announcements leading to much larger changes in stock volumes than in prices.

\subsection{Tax news regressions}

Table 14 brings together the various dummy variables employed above in the sub-sample analysis in Table 12 and presents the results of a set of multiple regressions where the dependent variable is the CAR over a particular window and the independent variables are the standard style attribution regressors (beta, book-to-market ratio, market capitalisation, prior return and idiosyncratic risk)

\footnotetext{
${ }^{48}$ Space constraints prevent us from displaying the entire event window since it is of interest here to examine each day within the window individually.

${ }^{49}$ Note that for the small firm, culpable and expatriation sub-samples the number of observations is modest and therefore achieving statistical significance is difficulty even when economically the ratios are a long way from one.
} 
employed previously together with a set of 0-1 dummy variables that characterise the nature of the news and of the firm it is being reported on. Overall, these results confirm those of the simple univariate approach described in the previous sub-section. The key result is that all of the intercepts in these regressions are negative and highly significant, indicating that once these various factors have been taken into account, the average CAR is negative over all parts of the event window. Most of the other signs vary according to the timing of the window under investigation relative to the news story but in general, small firms and those with high book-to-market ratios (value stocks) are worse affected by news stories. Almost none of the dummy variables are statistically significant but share price reactions to tax-related news stories have become less negative over time and firms that are subject to new stories regarding expatriations have highly significant price falls.

We also include in the regressions reported in Table 12 a tax measure: CETR in Panel A of the table and GETR in Panel B. The estimates from the two are similar in signs and magnitude and suggest that on the event date in particular, firms which are already paying a higher rate of tax are less affected so that their share prices fall less, although there is some variation during the rest of the event window. A similar result was observed in Hanlon and Slemrod's (2009) investigation of tax shelter news stories in the UK, although their stronger negative share price reaction for consumer-facing firms is not replicated here. It might be that evidence that a firm is taking steps to reduce its tax bill is less negatively viewed when this is occurring relative to a high starting point or it might be that firms with high effective tax rates have in essence built up a stock of reputational goodwill regarding their tax matters that they are able to draw upon and which therefore provides a buffer against stronger share price reactions when bad stories about them hit the press.

\section{Conclusions}

This study conducts a broad-based analysis for the UK of the link between a firm's corporation tax payments and its financial performance as measured by the stock price. We find no correlation between any of the various measures of tax payment and stock returns (except for an isolated link with the industry average-adjusted CETR), although high effective tax rate firms have, all else equal, less risky stock price movements. A firm being mentioned in the news in relation to possible allegations of tax avoidance does not lead to any long-term fall in its stock price, although there are temporary falls around the time of the news announcement, especially for small firms, those where there is a mention of an investigation by the revenue authorities or similar, and where firms are relocating their headquarters primarily for tax reasons.

Our results on the lack of link between tax variables and financial performance are perhaps unsurprising and accord with the balance of the existing evidence for the US. The finding that trading volumes spike but prices move less are also consistent with the notion that while there may be sub- 
groups of 'responsible' investors who care deeply about tax avoidance, for the vast majority of others it is simply not a salient issue. If we assume that firms' senior managers know their businesses and that they work in shareholders' best interests, they will have evaluated the costs and benefits of tax avoidance and therefore any changes in tax rates for a given firm will represent the outcome of a measured, rational decision process within the firm. Following that line of argument, such changes in tax rates will not reveal any new information about either the financial health of the firm beyond those revealed in the accounts more broadly or about the quality of its management.

In summary, as far as investors are concerned, senior managers choosing to avoid taxes more or less aggressively are unlikely to affect stock prices one way or the other, even in the short term, provided that they remain well within the realms likely to be deemed acceptable by the revenue authorities. However, all else being equal, companies that are paying higher effective tax rates will be perceived as less risky investments by shareholders. Therefore, if other stakeholder groups representing various sections of society perceive that firms are paying insufficient corporate tax, the onus is very much on the government to redefine the rules to ensure that aggressive avoidance practices are established as being unambiguously outside of legal boundaries.

Our findings concerning investors' revealed preferences regarding corporation tax are entirely redolent of the wider literature on the association between corporate social responsibility and financial performance where a roughly equal number of studies have found a positive relationship compared with those finding a negative one, with yet more research uncovering no link at all. ${ }^{50}$ The negative association between tax payment and risk also mirrors the corresponding findings in the CSR literature where socially irresponsible firms exhibit higher levels of financial market risk (Oikonomou et al., 2012).

Even in the most extreme cases of tax avoidance, consumers' collective memories fade as they gradually revert back to their previous consumption patterns. By way of illustration, in 2011-12 Starbucks became widely viewed as representing the very epitome of tax avoidance in the UK as discussed in the introduction to this study and yet their coffee shops are once again buzzing and for the first time since they began trading in the UK they have reported (albeit very small) positive profits here. ${ }^{51}$ Therefore, if bottom line profitability is not hit even in the context of the allegedly most egregious degrees of tax avoidance, why should investors care? It seems that most of them do not care unless any poor practice by the firm is likely to have a direct and self-destructive financial

\footnotetext{
${ }^{50}$ Examples from among this vast body of research finding a positive link include Hillman and Keim (2001); for the negative link see Brammer et al. (2006); examples finding no overall relationship include Renneboog et al. (2008) and Bauer et al. (2005).

${ }^{51}$ See www.theguardian.com/business/2015/feb/04/starbucks-first-uk-profits. Of course, one could argue that in the absence of the consumer backlash they faced in 2011 to 2012, in particular, their profit levels would be even higher. A conspiracist might further argue that measured UK profitability has grown precisely because the company is bringing more of its income back onshore, in fact their actual profitability is unchanged.
} 
consequence. Share prices are continually buffeted by as myriad of news, even at the firm-specific level. Tax-related information is but one tiny piece of a much larger corporate puzzle that analysts, fund managers, proprietary traders and retail investors must take into consideration when evaluating companies and making buy, hold or sell recommendations or decisions.

\section{Acknowledgements}

The authors would like to thank Deloitte for their financial contribution towards the cost incurred in conducting this study. We are very grateful an anonymous referee for extensive and constructive comments on a previous version of this paper. We are also grateful to Lisa Schopohl and Nicole Tovstiga for excellent research assistance. We appreciate the comments of Mark Kennedy and Alexandra Warren of Deloitte on a previous version of this document. Finally, we thank seminar participants at the Universities of Kent and Loughborough for their useful feedback. The authors alone are responsible for any errors.

\section{References}

Agarwal, V and Taffler, R (2008) Does financial distress risk drive the momentum anomaly? Financial Management, 37, 461-84

Anderson, K and Brooks, C (2014) Speculative bubbles and the cross-sectional variation in stock returns. International Review of Financial Analysis, 35, 20-31

Arena, M P and Roper, A H (2010) The effect of taxes on multinational debt location. Journal of Corporate Finance, 16(5), 637-654.

Armitage, S (1995) Event study methods and evidence on their performance. Journal of Economic Surveys, 8(4), 25-52

Austin, C R and Wilson, R (2013) Are reputational costs a determinant of tax avoidance? Working Paper. University of Iowa

Ayers, B, Laplante, S and McGuire, S (2010) Credit ratings and taxes: The effect of book tax differences on rating changes. Contemporary Accounting Research, 27(2), 359-402

Badertscher, B, Katz, S P and Rego, S O (2009) The impact of private equity ownership on corporate tax avoidance. Working Paper 10-004, Harvard Business School

Bali, T G and Cakici, N (2008) Idiosyncratic volatility and the cross-section of expected returns. Journal of Financial and Quantitative Analysis, 43, 29-58

Bali, T G, Cakici, N, Yan, X and Zhang, Z (2005) Does idiosyncratic risk really matter? Journal of Finance, 60, 905-29

Barber, B M and Odean, T (2008) All that glitters: the effect of attention and news on the buying behaviour of individuals and institutional investors. Review of Financial Studies, 21(2), 785-818 
Bauer, R, Koedijk, K and Otten, R (2005) International evidence on ethical mutual fund performance and investment style. Journal of Banking and Finance, 29, 1751-67

Beneish, M, Whaley, R (1996) An anatomy of the 'S\&P game': the effects of changing the rules. Journal of Finance, 51(5), 1909-30

Berger, J, Sorensen, A T and Rasmussen, S J (2010) Positive effects of negative publicity: When negative reviews increase sales. Marketing Science, 29(5), 815-27

Bosch, J C and Eckard, E W (1991) The profitability of price fixing: Evidence from stock market reaction to federal indictments. Review of Economics and Statistics, 73, 309-17

Botosan, C A (1997) Disclosure level and the cost of equity capital. Accounting Review, 72(3), 32349

Brammer, S, Brooks, C and Pavelin, S (2006) Corporate social performance and stock returns: UK evidence from disaggregate measures. Financial Management, 35, 97-116

Brooks, C (2014) Introductory Econometrics for Finance, 3rd ed. Cambridge, UK: Cambridge University Press

Brown, J, Drake, K and Martin, M (2013) Are firms myopic? The case of contracting on performance and risk. Working Paper, Arizona State University

Bushee, B J (2001) Do institutional investors prefer near-term earnings over long-run value? Contemporary Accounting Research, 18(2), 207-46

Campbell, J Y, Lettau, M, Malkiel, B G and Xu, Y (2001) Have individual stocks become more volatile? An empirical exploration of idiosyncratic risk. Journal of Finance, 56(1), 1-43

Carhart, M (1997) On the persistence of mutual fund performance. Journal of Finance, 52, 57-82

Chen, S, Chen, X, Cheng, Q and Shevlin, T (2010) Are family firms more tax aggressive than nonfamily firms? Journal of Financial Economics, 95(1), 41-61

Cheng, A, Huang, H H, Li, Y and Stanfield, J (2012) The effect of hedge fund activism on corporate tax avoidance. Accounting Review, 87(5), 1493-526

Choy, S K, Lai, T and Ng, T (2014) Do treasure islands create firm value? Working Paper, Shanghai University of Finance and Economics, Copenhagen Business School and the Chinese University of Hong Kong

Christensen, D M, Dhaliwal, D S, Boivie, S and Graffin, S D (2015) Top management conservatism and corporate risk strategies: Evidence from managers' personal political orientation and corporate tax avoidance. Strategic Management Journal, 36(12), 1918-38

Cloyd, C B, Pratt, J and Stock, T (1996) The use of financial accounting choice to support aggressive tax positions: Public and private firms. Journal of Accounting Research, 34(1), 23-43

Cloyd, C B, Mills, L F and Weaver, C D (2003) Firm valuation effects of the expatriation of US corporations to tax haven countries. Journal of the American Taxation Association, 25(Supplement), 87-109 
Cook, K A, Moser, W J and Omer, T C (2013) Towards an optimal level of tax avoidance. Working Paper, Texas Tech University, Miami University of Ohio and University of Nebrasca - Lincoln

Cowan, A R and Sergeant, A M A (2001) Interacting biases, non-normal return distributions and the performance of tests for long-horizon event studies. Journal of Banking and Finance, 25, 741-65

Crabtree, A and Maher, J (2009) The influence of differences in taxable income and book income on the bond credit market. Journal of the American Tax Association, 31(1), 75-99

Dechow, P, Sloan, R and Sweeney, A (1996) Causes and consequences of accounting manipulation: An analysis of firms subject to enforcement actions by the SEC. Contemporary Accounting Research, 13, 1-36

Desai, M A and Dharmapala, D (2006) Corporate tax avoidance and high powered incentives. Journal of Financial Economics, 79(1), 145-79

Desai, M A and Dharmapala, D (2009) Corporate tax avoidance and firm value. Review of Economics and Statistics, 91(3), 537-46

Desai, M A, Foley, C F and Hines, J R, Jr (2006) The demand for tax haven operations. Journal of Public Economics, 90, 513-31

Devereux, M, Lockwood, B and Redoano, M (2008) Do countries compete over corporate tax rates? Journal of Public Economics, 92(5-6), 1210-35

Dhaliwal, D and Erickson, M (1998) Wealth effects of tax-related court rulings. Journal of the American Tax Association, 20(1), 21-49

Dharmapala, D (2008) What problems and opportunities are created by tax havens? Oxford Review of Economic Policy, 24(4), 661-79

Dunbar, A, Higgins, D, Phillips, J and Plesko, G (2010) What do measures of tax aggressiveness measure? National Tax Association Annual Conference Proceedings

Dyreng, S D, Hanlon, M and Maydew, E L (2008) Long-run corporate tax avoidance. Accounting Review, 83(1), 61-82

Dyreng, S D, Hoopes, J L and Wilde, J H (2014) Public pressure and corporate tax behavior. Working Paper, Duke University, Ohio State University and University of Iowa

Fama, E F and French, K R (1992) The cross-section of expected stock returns. Journal of Finance, $47(2), 427-65$

Fama, E F and French, K R (1996) The CAPM is wanted, dead or alive. Journal of Finance, 51(5), $1947-58$

Fama, E F and French, K R (2012) Size, value, and momentum in international stock returns. Journal of Financial Economics, 105, 457-72

Fama, E F and MacBeth, J D (1973) Risk, returns, and equilibrium: Empirical tests. Journal of Political Economy, 81, 607-36

Gallemore, J, Maydew, E and Thornock, J R (2014) The reputational costs of tax avoidance. Contemporary Accounting Research, 31(4), 1103-33 
Garbade, K D, Silber, W L and White, L J (1982) Market reaction to the filing of antitrust suits: An aggregate and cross-section analysis. Review of Economics and Statistics, 64, 686-91

Garbarino, C (2011) Aggressive tax strategies and corporate tax avoidance: An institutional approach. European Company and Financial Law Review, 8(3), 277-304

Graham, J R and Tucker, A (2006) Tax shelters and corporate debt policy. Journal of Financial Economics, 81(3), 563-94

Graham, J R, Hanlon, M, Shevlin, T and Shroff, N (2013) Incentives for tax planning and avoidance: Evidence from the field. Accounting Review, 89(3), 991-1023

Guenther, D A, Matsunaga, S R and Williams, B M (2013) Tax avoidance, tax aggressiveness, tax risk and firm risk. Working Paper, Lundquist College of Business

Hale, J E, Dulek, R E, \& Hale, D P (2005). Crisis response communication challenges. Journal of Business Communication, 42, 112-134

Hanlon, M and Heitzman, S (2010) A review of tax research. Journal of Accounting and Economics, $50,127-78$

Hanlon, M and Slemrod, J (2009) What does tax aggressiveness signal? Evidence from stock price reactions to news about tax shelter involvement. Journal of Public Economics 93, 126-41

Hanlon, M, Laplante, S K and Shevlin, T (2005) Evidence for the possible information loss of conforming book income and taxable income. Journal of Law and Economics, 68, 407-42

Harrington, C and Smith, W (2012) Tax avoidance and corporate capital structure. Journal of Finance and Accountancy, 11, 1-20

Harris, L, and Gurel, E (1986) Price and volume effects associated with changes in the S\&P 500 list: New evidence for the existence of price pressures. Journal of Finance, 41(4), 815-29

Hasan, I, Hoi, C K, Wu, Q and Zhang, H (2014) Beauty is in the eye of the beholder: The effect of corporate tax avoidance on the cost of bank loans. Journal of Financial Economics, 113, 109-30

Hasseldine, J and Morris, G (2013) Corporate social responsibility and tax avoidance: A comment and reflection. Accounting Forum, 37, 1-14

Hillman, A J and Keim, G D (2001) Shareholder value, stakeholder management, and social issues: What's the bottom line? Strategic Management Journal, 22, 125-39

Huseynov, F and Klamm, B K (2012) Tax avoidance, tax management and corporate social responsibility. Journal of Corporate Finance 18(4), 804-27

Jacob, M and Schütt, H (2013) Firm valuation and the uncertainty of future tax avoidance. Working Paper 13/2013, FAccT Center

Kappou, K, Brooks, C and Ward, C W R (2008) A re-examination of the index effect: Gambling on additions to and deletions from the S\&P 500's 'gold seal'. Research in International Business and Finance, 22, 325-50

Karpoff, J, Lee, S and Martin, G (2008a) The consequences to managers for financial misrepresentation. Journal of Financial Economics, 88, 193-215 
Karpoff, J, Lee, S and Martin, G (2008b) The cost to firms of cooking the books. Journal of Financial and Quantitative Analysis, 43, 581-612

Khurana, I K and Moser, W J (2013) Institutional shareholders' investment horizons and tax avoidance. Journal of the American Tax Association, 35(1), 111-34

Kim, J-B, Li, Y and Zhang, L (2011) Corporate tax avoidance and stock price crash risk: Firm-level analysis. Journal of Financial Economics, 100(3), 639-62

Klassen, K J and Laplante, S K (2012) Are US multinational corporations becoming more aggressive income shifters? Journal of Accounting Research, 50(5), 1245-85

Kleinbard, E D (2013) Through a latte darkly: Starbucks' stateless income planning. Tax Notes, 24 June, 1515-35

Koku, P S, Akhigbe, A and Springer, T M (1997) The financial impact of boycotts and threats of boycott. Journal of Business Research, 40, 15-20

Lambert, R, Leuz, C and Verrecchia, R E (2007) Accounting information, disclosure and the cost of capital. Journal of Accounting Research, 45(2), 385-420

Lev, B and Nissim, D (2004) Taxable income, future earnings and equity values. Accounting Review, 79, 1039-74

Li, X, Brooks, C and Miffre, J (2009) The value premium and time-varying volatility. Journal of Business Finance \& Accounting, 36(9-10), 1252-72

MacKinlay, A C (1997) Event studies in economics and finance. Journal of Economic Literature, 55, 13-39

MacPherson, A, Kennedy, M, Egert, J and Lucas, B (2009) United Kingdom. In: A Bakker and S Kloosterhof (eds) Tax Risk Management: From Risk to Opportunity. Amsterdam: International Bureau of Fiscal Documentation (IBFD)

Mills, L (1998) Book-tax differences and internal revenue service adjustments. Journal of Accounting Research, 36, 343-56

Morisset, J and Pirnia, N (2000) How Tax Policy and Incentives Affect Foreign Direct Investment: A Review. Washington: World Bank and International Finance Corporation Foreign Investment Advisory Service

Neuman, S S (2014) Effective tax strategies: It's not just minimization. Working Paper, University of Missouri

Neuman, S S, Omer, T and Schmidt, A (2013) Risk and return: Does tax risk reduce firms' effective tax rates. Working Paper, Texas A\&M University and North Carolina State University

Ohlson, J and Penman, S (1992) Disaggregated accounting data as explanatory variables for returns. Journal of Accounting, Auditing and Finance, 4, 553-73

Oikonomou, I, Brooks, C and Pavelin, S (2012) The impact of corporate social performance on financial risk and utility: A longitudinal analysis. Financial Management, 41(2), 483-515 
Oikonomou, I, Brooks, C and Pavelin, S (2014) The interactive financial effects of corporate social responsibility and irresponsibility. Journal of Management Studies, 51(6), 898-925

Pruitt, S W and Friedman, M (1986) Determining the effectiveness of consumer boycotts: A stock price analysis of their impact on corporate targets. Journal of Consumer Policy, 9, 375-87

Rego, S O and Wilson, R (2012) Equity risk incentives and corporate tax aggressiveness. Journal of Accounting Research, 50(3), 775-810

Renneboog, L, Ter Horst, J and Zhang, C (2008) The price of ethics and stakeholder governance: The performance of socially responsible mutual funds. Journal of Corporate Finance, 14(3), 302-22

Richardson, G, Lanis, R, Leung, S C (2014) Corporate tax aggressiveness, outside directors, and debt policy: An empirical analysis. Journal of Corporate Finance, 25, 107-121

Rondinelli, D and Burpitt, W J (2000) Do government incentives attract and retain international investment? A study of foreign-owned firms in North Carolina. Policy Studies, 33, 181-205

Seida, J A and Wempe, W F (2004) Effective tax rate changes and earnings stripping following corporate inversion. National Tax Journal, 57(4), 805-28

Shanken, J (1992) On the estimation of beta-pricing models. Review of Financial Studies, 5(1), 1-33

Shevlin, T, Urcan, O and Vasvari, F (2013) Corporate tax avoidance and public debt costs. Working Paper, University of California, Irvine

Sikka, P and Willmott, H (2010) The dark side of transfer pricing: Its role in tax avoidance and wealth retentiveness. Critical Perspectives on Accounting, 21, 342-56

Slemrod, J (2004) The economics of corporate tax selfishness. National Tax Journal, 57, 877-99

Thomas, J and Zhang, F (2011) Tax expense momentum. Journal of Accounting Research, 49(3), $791-821$

Van Hoye, G and Lievens, F (2005) Recruitment-related information sources and organizational attractiveness: Can something be done about negative publicity? International Journal of Selection and Assessment, 13, 179-87

Voget, J (2011) Relocation of headquarters and international taxation. Journal of Public Economics, 95, 1067-81

Williams, R J and Barrett, J D (2000) Corporate philanthropy, criminal activity, and firm reputation: Is there a link? Journal of Business Ethics, 26, 341-50

Wilson, R (2009) An examination of corporate tax shelter participants. Accounting Review, 84(3), 969-99 


\section{Appendix 1: Variable definitions and Compustat Global mnemonics}

Fixed assets $\mathrm{it}_{\mathrm{it}}=$ property, plant and equipment divided by lagged total assets $=$ ppent $_{\mathrm{it}} / \mathrm{ta}_{\mathrm{it}-1}$

Intangible assets $s_{i t}=$ intangible assets divided by lagged total assets $=\operatorname{intan}_{\mathrm{it}} / \mathrm{ta}_{\mathrm{it}-1}$

$\mathrm{R} \& \mathrm{D}$ expenditure ${ }_{\mathrm{it}}=\mathrm{R} \& \mathrm{D}$ expenditure divided by lagged total assets $=\mathrm{xrd}_{\mathrm{it}} / \mathrm{ta}_{\mathrm{it}-1}$

$\mathrm{D} / \mathrm{E}_{\mathrm{it}}=$ debt to equity ratio $=\left(\mathrm{dd} 1_{\mathrm{it}}+\mathrm{dltt}_{\mathrm{it}}\right) /$ market cap $_{\mathrm{it}-1}$

Return on equity, $\mathrm{ROE}_{\mathrm{it}}=\left(\mathrm{pi}_{\mathrm{it}}-\mathrm{spi}_{\mathrm{it}}\right) /$ market cap at prior year end

Return on assets, $\mathrm{ROA}_{\mathrm{it}}=\mathrm{pi}_{\mathrm{it}}-\mathrm{spi}_{\mathrm{it}} / \mathrm{ta}_{\mathrm{it}-1}$

The book-to-market ratio BTM = book equity / market capitalisation at prior year end

$=\left(\mathrm{ceq}_{\mathrm{it}}+\mathrm{txditc}_{\mathrm{it}}-\mathrm{pstk}_{\mathrm{it}}\right) /$ market cap at prior year end

Scaled cash holdings $=\mathrm{che}_{\mathrm{it}} / \mathrm{ta}_{\mathrm{it}-1}$ i.e. scaled by lagged total assets

Cash holdings $=$ che $_{\mathrm{it}}$

beta $_{i t}$ is the market beta of the stock with respect to the excess monthly returns of the FTSE All-Share Index, over a minimum of 24 and a maximum of 60 prior months

Profit $_{\mathrm{it}}=\mathrm{pi}_{\mathrm{it}}-\mathrm{spi}_{\mathrm{it}}$

Sales growth $\mathrm{it}=\left(\mathrm{sale}_{\mathrm{t}}-\mathrm{sale}_{\mathrm{t}-1}\right) / \mathrm{sale}_{\mathrm{t}-1}$ 
Table 1 Summary statistics for tax data and other key variables

\begin{tabular}{|c|c|c|c|c|c|c|c|c|}
\hline \multirow[t]{2}{*}{ Variable } & \multirow[t]{2}{*}{$\mathrm{N}$} & \multirow[t]{2}{*}{ Mean } & \multirow[t]{2}{*}{ Std Dev } & \multicolumn{5}{|c|}{ Percentiles } \\
\hline & & & & 5 & 25 & 50 & 75 & 95 \\
\hline CETR & 10729 & 0.24 & 0.17 & 0.00 & 0.09 & 0.27 & 0.34 & 0.49 \\
\hline GETR & 10891 & 0.29 & 0.14 & 0.04 & 0.24 & 0.30 & 0.34 & 0.47 \\
\hline BTD & 10110 & 0.04 & 0.12 & -0.05 & -0.01 & 0.01 & 0.05 & 0.27 \\
\hline Perm_BTD & 10264 & 0.01 & 0.05 & -0.05 & -0.01 & 0.00 & 0.02 & 0.08 \\
\hline TPS5_CETR & 6983 & 22.10 & 208.81 & 0.59 & 3.48 & 7.43 & 17.90 & 53.03 \\
\hline TPS5_GETR & 7268 & 27.83 & 204.89 & 0.58 & 4.10 & 11.49 & 27.43 & 77.88 \\
\hline $\log$ (market cap) & 14315 & 6.04 & 1.61 & 3.93 & 4.80 & 5.77 & 7.07 & 9.03 \\
\hline log(total assets) & 12343 & 6.27 & 1.99 & 3.56 & 4.86 & 6.01 & 7.43 & 9.98 \\
\hline Intangible assets & 11451 & 0.65 & 45.63 & 0.00 & 0.00 & 0.02 & 0.21 & 0.66 \\
\hline fixed assets & 11585 & 3.46 & 334.09 & 0.01 & 0.09 & 0.28 & 0.51 & 0.93 \\
\hline$R \& D$ expenditure & 3737 & 0.06 & 0.15 & 0.00 & 0.00 & 0.02 & 0.06 & 0.24 \\
\hline $\mathrm{D} / \mathrm{E}$ ratio & 12074 & 0.49 & 5.49 & 0.00 & 0.01 & 0.13 & 0.34 & 1.14 \\
\hline Leverage & 11625 & 0.58 & 37.62 & 0.00 & 0.02 & 0.12 & 0.25 & 0.56 \\
\hline ROE & 12016 & 0.19 & 6.14 & -0.05 & 0.06 & 0.09 & 0.13 & 0.23 \\
\hline ROA & 11616 & 0.39 & 31.00 & -0.05 & 0.04 & 0.09 & 0.15 & 0.31 \\
\hline $\mathrm{BE} / \mathrm{ME}$ & 12074 & 1.12 & 28.62 & 0.05 & 0.26 & 0.45 & 0.75 & 1.53 \\
\hline Cash holdings & 10340 & 0.24 & 4.20 & 0.00 & 0.04 & 0.09 & 0.19 & 0.51 \\
\hline Profit & 11791 & 286.79 & 1811.56 & -11.72 & 8.87 & 27.40 & 114.38 & 897.00 \\
\hline Sales growth & 10292 & 0.25 & 4.74 & -0.18 & 0.00 & 0.08 & 0.20 & 0.69 \\
\hline CAPM beta & 12003 & 1.02 & 0.55 & 0.23 & 0.67 & 0.99 & 1.29 & 2.00 \\
\hline Idiosyncratic volatility & 12673 & 0.02 & 0.01 & 0.01 & 0.01 & 0.01 & 0.02 & 0.04 \\
\hline
\end{tabular}


Table 2 Time series of cross-sectional regressions for the impact of tax and other variables on monthly returns (tax measure: CETR)

\begin{tabular}{|c|c|c|c|c|}
\hline \multirow[t]{2}{*}{ Independent variables } & \multicolumn{4}{|c|}{ Dependent variable: excess monthly returns } \\
\hline & $(1)$ & $(2)$ & (3) & $(4)$ \\
\hline Intercept & $\begin{array}{l}-0.0150 \\
(-3.589)^{\star \star *}\end{array}$ & $\begin{array}{l}0.0083 \\
(2.688)^{\star \star \star}\end{array}$ & $\begin{array}{l}-0.0095 \\
(-2.278)^{\star *}\end{array}$ & $\begin{array}{l}-0.0149 \\
(-3.551)^{\star *}\end{array}$ \\
\hline CETR & - & $\begin{array}{l}0.0003 \\
(0.254)\end{array}$ & $\begin{array}{l}0.0006 \\
(0.456)\end{array}$ & $\begin{array}{l}0.0009 \\
(0.725)\end{array}$ \\
\hline CAPM beta & $\begin{array}{l}-0.0008 \\
(-0.181)\end{array}$ & $\begin{array}{l}-0.0029 \\
(-0.635)\end{array}$ & $\begin{array}{l}0.0006 \\
(0.120)\end{array}$ & $\begin{array}{l}-0.0009 \\
(-0.200)\end{array}$ \\
\hline $\mathrm{B} / \mathrm{M}$ ratio & $\begin{array}{l}-0.0004 \\
(-0.626)\end{array}$ & - & $\begin{array}{l}-0.0002 \\
(-0.325)\end{array}$ & $\begin{array}{l}-0.0004 \\
(-0.598)\end{array}$ \\
\hline Log(market cap) & $\begin{array}{l}0.0016 \\
(2.541)^{\star \star}\end{array}$ & - & $\begin{array}{l}0.0012 \\
(1.943)^{*}\end{array}$ & $\begin{array}{l}0.0016 \\
(2.508)^{\star *}\end{array}$ \\
\hline Previous year's returns & $\begin{array}{l}0.0786 \\
(27.429)^{\star \star \star}\end{array}$ & - & $\begin{array}{l}0.0745 \\
(26.648)^{\star * \star}\end{array}$ & $\begin{array}{l}0.0785 \\
(27.332)^{\star *}\end{array}$ \\
\hline Idiosyncratic volatility & $\begin{array}{l}0.2475 \\
(3.796)^{\star * *}\end{array}$ & - & - & $\begin{array}{l}0.2543 \\
(3.900)^{\star * *}\end{array}$ \\
\hline $\mathrm{N}$ & 392 & 392 & 392 & 392 \\
\hline Adjusted $\mathrm{R}^{2}$ & 0.178 & 0.056 & 0.172 & 0.183 \\
\hline
\end{tabular}

Notes: t-ratios in parentheses; $*, * *$ and $* * *$ denote significance at the $10 \%, 5 \%$ and $1 \%$ levels respectively. Fama-MacBeth cross-sectional regressions conducted across 286 months with Shanken corrections to the intercept and slope estimate on the CAPM beta.

Table 3 Time series of cross-sectional regressions for the impact of tax and other variables on monthly returns (tax measure: GETR)

\begin{tabular}{|c|c|c|c|c|}
\hline \multirow[t]{2}{*}{ Independent variables } & \multicolumn{4}{|c|}{ Dependent variable: excess monthly returns } \\
\hline & (1) & (2) & (3) & (4) \\
\hline Intercept & $\begin{array}{l}-0.0170 \\
(-3.940)^{\star * *}\end{array}$ & $\begin{array}{l}0.0055 \\
(1.770)^{*}\end{array}$ & $\begin{array}{l}-0.0120 \\
(-2.782)^{\star * *}\end{array}$ & $\begin{array}{l}-0.018 \\
(-4.028)^{\star * *}\end{array}$ \\
\hline GETR & - & $\begin{array}{l}0.0056 \\
(1.911)^{*}\end{array}$ & $\begin{array}{l}0.0010 \\
(0.381)\end{array}$ & $\begin{array}{l}0.002 \\
(0.669)\end{array}$ \\
\hline CAPM beta & $\begin{array}{l}0.0003 \\
(0.075)\end{array}$ & $\begin{array}{l}-0.0017 \\
(-0.394)\end{array}$ & $\begin{array}{l}0.0019 \\
(0.423)\end{array}$ & $\begin{array}{l}0.000 \\
(0.061)\end{array}$ \\
\hline $\mathrm{B} / \mathrm{M}$ ratio & $\begin{array}{l}-0.0003 \\
(-0.500)\end{array}$ & - & $\begin{array}{l}-0.0001 \\
(-0.207)\end{array}$ & $\begin{array}{l}0.000 \\
(-0.346)\end{array}$ \\
\hline Log(market cap) & $\begin{array}{l}0.0017 \\
(2.785)^{\star \star \star}\end{array}$ & - & $\begin{array}{l}0.0014 \\
(2.185)^{\star *}\end{array}$ & $\begin{array}{l}0.002 \\
(2.790)^{\star \star \star}\end{array}$ \\
\hline Previous year's returns & $\begin{array}{l}0.0775 \\
(26.354)^{\star * *}\end{array}$ & - & $\begin{array}{l}0.0733 \\
(26.008)^{\star \star \star}\end{array}$ & $\begin{array}{l}0.077 \\
(26.377)^{\star \star *}\end{array}$ \\
\hline Idiosyncratic volatility & $\begin{array}{l}0.2529 \\
(3.834)^{\star \star \star}\end{array}$ & - & - & $\begin{array}{l}0.255 \\
(3.831)^{\star \star \star}\end{array}$ \\
\hline $\mathrm{N}$ & 411 & 411 & 411 & 411 \\
\hline Adjusted $\mathrm{R}^{2}$ & 0.175 & 0.055 & 0.168 & 0.179 \\
\hline
\end{tabular}

Notes: t-ratios in parentheses; $* * *$ and $* * *$ denote significance at the $10 \%, 5 \%$ and $1 \%$ levels respectively. Fama-MacBeth cross-sectional regressions conducted across 286 months with Shanken corrections to the intercept and slope estimate on the CAPM beta. 
Table 4 Time series of cross-sectional regressions for the impact of tax and other variables on monthly returns (tax measure: book tax difference)

\begin{tabular}{|c|c|c|c|c|}
\hline \multirow[t]{2}{*}{ Independent variables } & \multicolumn{4}{|c|}{ Dependent variable: excess monthly returns } \\
\hline & $(1)$ & $(2)$ & (3) & $(4)$ \\
\hline Intercept & $\begin{array}{l}-0.016 \\
(-3.806)^{* * *}\end{array}$ & $\begin{array}{l}0.0076 \\
(2.508)^{\star *}\end{array}$ & $\begin{array}{l}-0.0108 \\
(-2.569)^{\star \star}\end{array}$ & $\begin{array}{l}-0.0155 \\
(-3.687)^{\star \star \star}\end{array}$ \\
\hline BTD & - & $\begin{array}{l}0.0013 \\
(0.172)\end{array}$ & $\begin{array}{l}-0.0090 \\
(-1.317)\end{array}$ & $\begin{array}{l}-0.0077 \\
(-1.144)\end{array}$ \\
\hline CAPM beta & $\begin{array}{l}-0.001 \\
(-0.136)\end{array}$ & $\begin{array}{l}-0.0026 \\
(-0.566)\end{array}$ & $\begin{array}{l}0.0008 \\
(0.181)\end{array}$ & $\begin{array}{l}-0.0006 \\
(-0.135)\end{array}$ \\
\hline $\mathrm{B} / \mathrm{M}$ ratio & $\begin{array}{l}0.000 \\
(-0.739)\end{array}$ & - & $\begin{array}{l}-0.0005 \\
(-0.666)\end{array}$ & $\begin{array}{l}-0.0007 \\
(-1.006)\end{array}$ \\
\hline Log(market cap) & $\begin{array}{l}0.002 \\
(2.832)^{\star \star *}\end{array}$ & - & $\begin{array}{l}0.0015 \\
(2.350)^{* *}\end{array}$ & $\begin{array}{l}0.0018 \\
(2.867)^{\star \star *}\end{array}$ \\
\hline Previous year's returns & $\begin{array}{l}0.077 \\
(27.003)^{\star \star \star}\end{array}$ & - & $\begin{array}{l}0.0731 \\
(26.138)^{\star \star \star}\end{array}$ & $\begin{array}{l}0.0768 \\
(26.966)^{\star \star \star}\end{array}$ \\
\hline Idiosyncratic volatility & $\begin{array}{l}0.226 \\
(3.449)^{\star \star *}\end{array}$ & - & - & $\begin{array}{l}0.2259 \\
(3.448)^{\star * *}\end{array}$ \\
\hline $\mathrm{N}$ & 399 & 399 & 399 & 399 \\
\hline Adjusted $\mathrm{R}^{2}$ & 0.176 & 0.056 & 0.170 & 0.180 \\
\hline
\end{tabular}

Notes: t-ratios in parentheses; $* * *$ and $* * *$ denote significance at the $10 \%, 5 \%$ and $1 \%$ levels respectively. Fama-MacBeth cross-sectional regressions conducted across 286 months with Shanken corrections to the intercept and slope estimate on the CAPM beta.

Table 5 Time series of cross-sectional regressions for the impact of tax and other variables on monthly returns (tax measure: permanent book tax difference)

\begin{tabular}{|c|c|c|c|c|}
\hline \multirow[t]{2}{*}{ Independent variables } & \multicolumn{4}{|c|}{ Dependent variable: excess monthly returns } \\
\hline & (1) & $(2)$ & (3) & $(4)$ \\
\hline Intercept & $\begin{array}{l}-0.0170 \\
(-3.925)^{\star \star \star}\end{array}$ & $\begin{array}{l}0.0073 \\
(2.347)^{\star *}\end{array}$ & $\begin{array}{l}-0.0118 \\
(-2.796)^{\star \star \star}\end{array}$ & $\begin{array}{l}-0.0167 \\
(-3.897)^{\star * *}\end{array}$ \\
\hline Perm-BTD & - & $\begin{array}{l}0.0068 \\
(0.737)\end{array}$ & $\begin{array}{l}-0.0087 \\
(-1.068)\end{array}$ & $\begin{array}{l}-0.0061 \\
(-0.782)\end{array}$ \\
\hline CAPM beta & $\begin{array}{l}0.0000 \\
(0.005)\end{array}$ & $\begin{array}{l}-0.0018 \\
(-0.381)\end{array}$ & $\begin{array}{l}0.0018 \\
(0.379)\end{array}$ & $\begin{array}{l}0.0002 \\
(0.053)\end{array}$ \\
\hline $\mathrm{B} / \mathrm{M}$ ratio & $\begin{array}{l}-0.0003 \\
(-0.420)\end{array}$ & - & $\begin{array}{l}-0.0001 \\
(-0.177)\end{array}$ & $\begin{array}{l}-0.0003 \\
(-0.474)\end{array}$ \\
\hline Log(market cap) & $\begin{array}{l}0.0018 \\
(2.808)^{\star \star \star}\end{array}$ & - & $\begin{array}{l}0.0014 \\
(2.250)^{\star *}\end{array}$ & $\begin{array}{l}0.0017 \\
(2.779)^{\star * *}\end{array}$ \\
\hline Previous year's returns & $\begin{array}{l}0.0770 \\
(26.408)^{\star * *}\end{array}$ & - & $\begin{array}{l}0.0732 \\
(26.190)^{* * *}\end{array}$ & $\begin{array}{l}0.0770 \\
(26.543)^{\star \star \star}\end{array}$ \\
\hline Idiosyncratic volatility & $\begin{array}{l}0.2376 \\
(3.588)^{\star \star *}\end{array}$ & - & - & $\begin{array}{l}0.2355 \\
(3.580)^{\star * *}\end{array}$ \\
\hline $\mathrm{N}$ & 405 & 405 & 405 & 405 \\
\hline Adjusted $\mathrm{R}^{2}$ & 0.176 & 0.057 & 0.170 & 0.180 \\
\hline
\end{tabular}

Notes: t-ratios in parentheses; *, ** and *** denote significance at the $10 \%, 5 \%$ and $1 \%$ levels respectively. Fama-MacBeth cross-sectional regressions conducted across 286 months with Shanken corrections to the intercept and slope estimate on the CAPM beta. 
Table 6 Time series of cross-sectional regressions for the impact of tax and other variables on monthly returns (tax measure: $\Delta$ CETR)

\begin{tabular}{|c|c|c|c|c|}
\hline \multirow[t]{2}{*}{ Independent variables } & \multicolumn{4}{|c|}{ Dependent variable: excess monthly returns } \\
\hline & $(1)$ & $(2)$ & (3) & $(4)$ \\
\hline Intercept & $\begin{array}{l}-0.0150 \\
(-3.589)^{\star \star *}\end{array}$ & $\begin{array}{l}0.0083 \\
(2.688)^{\star * *}\end{array}$ & $\begin{array}{l}-0.0095 \\
(-2.278)^{\star *}\end{array}$ & $\begin{array}{l}-0.0149 \\
(-3.551)^{\star * \star}\end{array}$ \\
\hline$\triangle$ CETR & - & $\begin{array}{l}0.0003 \\
(0.254)\end{array}$ & $\begin{array}{l}0.0006 \\
(0.456)\end{array}$ & $\begin{array}{l}0.0009 \\
(0.725)\end{array}$ \\
\hline CAPM beta & $\begin{array}{l}-0.0008 \\
(-0.181)\end{array}$ & $\begin{array}{l}-0.0029 \\
(-0.635)\end{array}$ & $\begin{array}{l}0.0006 \\
(0.120)\end{array}$ & $\begin{array}{l}-0.0009 \\
(-0.200)\end{array}$ \\
\hline $\mathrm{B} / \mathrm{M}$ ratio & $\begin{array}{l}-0.0004 \\
(-0.626)\end{array}$ & - & $\begin{array}{l}-0.0002 \\
(-0.325)\end{array}$ & $\begin{array}{l}-0.0004 \\
(-0.598)\end{array}$ \\
\hline Log(market cap) & $\begin{array}{l}0.0016 \\
(2.541)^{\star *}\end{array}$ & - & $\begin{array}{l}0.0012 \\
(1.943)^{\star}\end{array}$ & $\begin{array}{l}0.0016 \\
(2.508)^{\star *}\end{array}$ \\
\hline Previous year's returns & $\begin{array}{l}0.0786 \\
(27.429)^{\star * *}\end{array}$ & - & $\begin{array}{l}0.0745 \\
(26.648)^{\star * *}\end{array}$ & $\begin{array}{l}0.0785 \\
(27.332)^{\star \star \star}\end{array}$ \\
\hline Idiosyncratic volatility & $\begin{array}{l}0.2475 \\
(3.796)^{\star * *}\end{array}$ & - & - & $\begin{array}{l}0.2543 \\
(3.900)^{\star * *}\end{array}$ \\
\hline $\mathrm{N}$ & 392 & 392 & 392 & 392 \\
\hline Adjusted $\mathrm{R}^{2}$ & 0.178 & 0.056 & 0.172 & 0.183 \\
\hline
\end{tabular}

Notes: t-ratios in parentheses; $*, * *$ and $* * *$ denote significance at the $10 \%, 5 \%$ and $1 \%$ levels respectively. Fama-MacBeth cross-sectional regressions conducted across 286 months with Shanken corrections to the intercept and slope estimate on the CAPM beta.

Table 7 Time series of cross-sectional regressions for the impact of tax and other variables on monthly returns (tax measure: $\Delta$ GETR)

\begin{tabular}{|c|c|c|c|c|}
\hline \multirow[t]{2}{*}{ Independent variables } & \multicolumn{4}{|c|}{ Dependent variable: excess monthly returns } \\
\hline & (1) & $(2)$ & (3) & $(4)$ \\
\hline Intercept & $\begin{array}{l}-0.0160 \\
(-3.699)^{\star * *}\end{array}$ & $\begin{array}{l}0.0075 \\
(2.395)^{\star *}\end{array}$ & $\begin{array}{l}-0.0103 \\
(-2.412)^{\star *}\end{array}$ & $\begin{array}{l}-0.0157 \\
(-3.635)^{\star * *}\end{array}$ \\
\hline$\Delta$ GETR & - & $\begin{array}{l}0.0010 \\
(0.823)\end{array}$ & $\begin{array}{l}-0.0001 \\
(-0.116)\end{array}$ & $\begin{array}{l}0.0003 \\
(0.269)\end{array}$ \\
\hline CAPM beta & $\begin{array}{l}-0.0002 \\
(-0.034)\end{array}$ & $\begin{array}{l}-0.0021 \\
(-0.457)\end{array}$ & $\begin{array}{l}0.0013 \\
(0.285)\end{array}$ & $\begin{array}{l}-0.0002 \\
(-0.051)\end{array}$ \\
\hline $\mathrm{B} / \mathrm{M}$ ratio & $\begin{array}{l}-0.0002 \\
(-0.348)\end{array}$ & - & $\begin{array}{l}-0.0001 \\
(-0.120)\end{array}$ & $\begin{array}{l}-0.0002 \\
(-0.350)\end{array}$ \\
\hline Log(market cap) & $\begin{array}{l}0.0016 \\
(2.521)^{\star *}\end{array}$ & - & $\begin{array}{l}0.0012 \\
(1.910)^{*}\end{array}$ & $\begin{array}{l}0.0015 \\
(2.472)^{\star *}\end{array}$ \\
\hline Previous year's returns & $\begin{array}{l}0.0792 \\
(26.698)^{\star \star \star}\end{array}$ & - & $\begin{array}{l}0.0750 \\
(26.235)^{\star \star \star}\end{array}$ & $\begin{array}{l}0.0792 \\
(26.564)^{\star * *}\end{array}$ \\
\hline Idiosyncratic volatility & $\begin{array}{l}0.2579 \\
(3.915)^{\star \star *}\end{array}$ & - & - & $\begin{array}{l}0.2578 \\
(3.920)^{\star \star \star}\end{array}$ \\
\hline $\mathrm{N}$ & 400 & 400 & 400 & 400 \\
\hline Adjusted $\mathrm{R}^{2}$ & 0.178 & 0.056 & 0.172 & 0.182 \\
\hline
\end{tabular}

Notes: absolute values of t-ratios in parentheses; *,** and *** denote significance at the $10 \%, 5 \%$ and $1 \%$ levels respectively. Fama-MacBeth cross-sectional regressions conducted across 286 months with Shanken corrections to the intercept and slope estimate on the CAPM beta. 
Table 8 Time series of cross-sectional regressions for the impact of tax and other variables on monthly returns (tax measure: CETR - deviation from industry average)

\begin{tabular}{|c|c|c|c|c|}
\hline \multirow[t]{2}{*}{ Independent variables } & \multicolumn{4}{|c|}{ Dependent variable: excess monthly returns } \\
\hline & (1) & $(2)$ & (3) & $(4)$ \\
\hline Intercept & $\begin{array}{l}-0.0141 \\
(-3.383)^{\star * *}\end{array}$ & $\begin{array}{l}0.0089 \\
(2.989)\end{array}$ & $\begin{array}{l}-0.0097 \\
(-2.329)^{\star *}\end{array}$ & $\begin{array}{l}-0.0139 \\
(-3.304)^{\star * *}\end{array}$ \\
\hline CETR & - & $\begin{array}{l}0.0043 \\
(2.295)^{\star \star}\end{array}$ & $\begin{array}{l}0.0030 \\
(1.656)^{\star}\end{array}$ & $\begin{array}{l}0.0036 \\
(1.995)^{\star \star}\end{array}$ \\
\hline CAPM beta & $\begin{array}{l}-0.0011 \\
(-0.244)\end{array}$ & $\begin{array}{l}-0.0033 \\
(-0.712)\end{array}$ & $\begin{array}{l}-0.0001 \\
(-0.006)\end{array}$ & $\begin{array}{l}-0.0012 \\
(-0.260)\end{array}$ \\
\hline $\mathrm{B} / \mathrm{M}$ ratio & $\begin{array}{l}-0.0002 \\
(-0.295)\end{array}$ & - & $\begin{array}{l}-0.0002 \\
(-0.294)\end{array}$ & $\begin{array}{l}-0.0002 \\
(-0.253)\end{array}$ \\
\hline Log(market cap) & $\begin{array}{l}0.0014 \\
(2.221)^{\star \star}\end{array}$ & - & $\begin{array}{l}0.0012 \\
(1.856)^{*}\end{array}$ & $\begin{array}{l}0.0014 \\
(2.175)^{\star \star *}\end{array}$ \\
\hline Previous year's returns & $\begin{array}{l}0.0798 \\
(27.466)^{\star * *}\end{array}$ & - & $\begin{array}{l}0.0763 \\
(26.626)^{\star * *}\end{array}$ & $\begin{array}{l}0.00798 \\
(27.352)^{\star * *}\end{array}$ \\
\hline Idiosyncratic volatility & $\begin{array}{l}0.220 \\
(3.239)^{\star \star \star}\end{array}$ & - & - & $\begin{array}{l}0.2168 \\
(3.191)^{\star \star \star}\end{array}$ \\
\hline $\mathrm{N}$ & 358 & 358 & 358 & 358 \\
\hline Adjusted $\mathrm{R}^{2}$ & 0.054 & 0.181 & 0.173 & 0.184 \\
\hline
\end{tabular}

Notes t-ratios in parentheses; $* * *$ and $* * *$ denote significance at the $10 \%, 5 \%$ and $1 \%$ levels respectively. Fama-MacBeth cross-sectional regressions conducted across 286 months with Shanken corrections to the intercept and slope estimate on the CAPM beta.

Table 9 Time series of cross-sectional regressions for the impact of tax and other variables on monthly returns (tax measure: GETR - deviation from industry average)

\begin{tabular}{|c|c|c|c|c|}
\hline \multirow[t]{2}{*}{ Independent variables } & \multicolumn{4}{|c|}{ Dependent variable: excess monthly returns } \\
\hline & $(1)$ & $(2)$ & (3) & $(4)$ \\
\hline Intercept & $\begin{array}{l}-0.0142 \\
(-3.415)^{\star \star *}\end{array}$ & $\begin{array}{l}0.0088 \\
(2.993)^{\star \star \star}\end{array}$ & $\begin{array}{l}-0.0097 \\
(-2.358)^{\star *}\end{array}$ & $\begin{array}{l}-0.0140 \\
(-3.369)^{\star * *}\end{array}$ \\
\hline GETR & - & $\begin{array}{l}0.0031 \\
(1.262)\end{array}$ & $\begin{array}{l}-0.0003 \\
(-0.120)\end{array}$ & $\begin{array}{l}0.0002 \\
(0.090)\end{array}$ \\
\hline CAPM beta & $\begin{array}{l}-0.0011 \\
(-0.237)\end{array}$ & $\begin{array}{l}-0.0031 \\
(-0.687)\end{array}$ & $\begin{array}{l}0.00001 \\
(0.009)\end{array}$ & $\begin{array}{l}-0.0012 \\
(-0.250)\end{array}$ \\
\hline $\mathrm{B} / \mathrm{M}$ ratio & $\begin{array}{l}-0.0001 \\
(-0.187)\end{array}$ & - & $\begin{array}{l}-0.0002 \\
(-0.222)\end{array}$ & $\begin{array}{l}-0.0001 \\
(-0.163)\end{array}$ \\
\hline Log(market cap) & $\begin{array}{l}0.0014 \\
(2.210)^{\star *}\end{array}$ & - & $\begin{array}{l}0.0012 \\
(1.837)^{\star}\end{array}$ & $\begin{array}{l}0.0014 \\
(2.160)^{\star \star}\end{array}$ \\
\hline Previous year's returns & $\begin{array}{l}0.0797 \\
(27.571)^{\star \star \star}\end{array}$ & - & $\begin{array}{l}0.0761 \\
(26.803)^{\star \star \star}\end{array}$ & $\begin{array}{l}0.0797 \\
(27.576)^{\star * \star}\end{array}$ \\
\hline Idiosyncratic volatility & $\begin{array}{l}0.2217 \\
(3.279)^{\star * *}\end{array}$ & - & - & $\begin{array}{l}0.2199 \\
(3.244)^{\star * *}\end{array}$ \\
\hline $\mathrm{N}$ & 363 & 363 & 363 & 363 \\
\hline Adjusted $\mathrm{R}^{2}$ & 0.181 & 0.055 & 0.174 & 0.185 \\
\hline
\end{tabular}

Notes: t-ratios in parentheses; *, ** and *** denote significance at the $10 \%, 5 \%$ and $1 \%$ levels respectively. Fama-MacBeth cross-sectional regressions conducted across 286 months with Shanken corrections to the intercept and slope estimate on the CAPM beta. 
Table 10 Random effects panel regressions of the effect of tax and other determinants on the CAPM beta measure of risk

\begin{tabular}{|c|c|c|c|c|c|c|}
\hline \multirow[t]{2}{*}{ Independent variables } & \multicolumn{6}{|c|}{ Dependent variable: CAPM beta } \\
\hline & CETR & CETR5 & GETR & GETR5 & BTD & PERM-BTD \\
\hline Tax measure & $\begin{array}{l}-0.1518 \\
(-4.868)^{\star \star \star}\end{array}$ & $\begin{array}{l}-0.1409 \\
(3.748)^{\star \star \star}\end{array}$ & $\begin{array}{l}-0.2171 \\
(5.343)^{\star \star \star}\end{array}$ & $\begin{array}{l}-0.1605 \\
(3.107)^{\star \star \star}\end{array}$ & $\begin{array}{l}0.2633 \\
(5.030)^{\star \star \star}\end{array}$ & $\begin{array}{l}1.0605 \\
(8.079)^{\star \star \star}\end{array}$ \\
\hline Log(Market cap) & $\begin{array}{l}-0.0816 \\
(9.111)^{\star \star \star}\end{array}$ & $\begin{array}{l}-0.1119 \\
(10.983)^{\star \star \star}\end{array}$ & $\begin{array}{l}-0.083 \\
(9.282)^{\star \star \star}\end{array}$ & $\begin{array}{l}-0.1146 \\
(11.302)^{\star \star \star}\end{array}$ & $\begin{array}{l}-0.0817 \\
(9.122)^{\star \star \star}\end{array}$ & $\begin{array}{l}-0.083 \\
(9.290)^{\star \star \star}\end{array}$ \\
\hline Log(total assets) & $\begin{array}{l}0.1311 \\
(14.181)^{\star \star \star}\end{array}$ & $\begin{array}{l}0.1552 \\
(14.445)^{\star \star \star}\end{array}$ & $\begin{array}{l}0.1330 \\
(14.464)^{\star \star \star}\end{array}$ & $\begin{array}{l}0.1588 \\
(14.926)^{\star \star \star}\end{array}$ & $\begin{array}{l}0.1301 \\
(14.038)^{\star \star \star}\end{array}$ & $\begin{array}{l}0.133 \\
(14.509)^{* * *}\end{array}$ \\
\hline Intangible assets & $\begin{array}{l}0.0111 \\
(0.596)\end{array}$ & $\begin{array}{l}0.0271 \\
(1.161)\end{array}$ & $\begin{array}{l}0.0186 \\
(0.997)\end{array}$ & $\begin{array}{l}0.0334 \\
(1.431)\end{array}$ & $\begin{array}{l}0.0104 \\
(0.558)\end{array}$ & $\begin{array}{l}0.0317 \\
(1.697)^{\star}\end{array}$ \\
\hline Fixed assets & $\begin{array}{l}-0.2676 \\
(12.208)^{\star \star \star}\end{array}$ & $\begin{array}{l}-0.3045 \\
(11.409)^{\star \star \star}\end{array}$ & $\begin{array}{l}-0.2733 \\
(12.487)^{\star \star \star}\end{array}$ & $\begin{array}{l}-0.3116 \\
(11.670)^{\star \star \star}\end{array}$ & $\begin{array}{l}-0.2657 \\
(12.115)^{\star \star \star}\end{array}$ & $\begin{array}{l}-0.2805 \\
(12.829)^{\star \star \star}\end{array}$ \\
\hline$R \& D$ expenditure & $\begin{array}{l}0.296 \\
(2.131)^{\star *}\end{array}$ & $\begin{array}{l}0.2280 \\
(1.191)\end{array}$ & $\begin{array}{l}0.2862 \\
(2.063)^{\star *}\end{array}$ & $\begin{array}{l}0.2209 \\
(1.152)\end{array}$ & $\begin{array}{l}0.2851 \\
(2.052)^{\star *}\end{array}$ & $\begin{array}{l}0.2414 \\
(1.742)^{*}\end{array}$ \\
\hline $\mathrm{D} / \mathrm{E}$ ratio & $\begin{array}{l}-0.0014 \\
(-1.194)\end{array}$ & $\begin{array}{l}0.0025 \\
(0.780)\end{array}$ & $\begin{array}{l}-0.0014 \\
(1.200)\end{array}$ & $\begin{array}{l}0.0025 \\
(0.791)\end{array}$ & $\begin{array}{l}-0.0015 \\
(1.269)\end{array}$ & $\begin{array}{l}-0.0015 \\
(1.259)\end{array}$ \\
\hline Leverage & $\begin{array}{l}0.0882 \\
(2.672)^{\star \star \star}\end{array}$ & $\begin{array}{l}0.0955 \\
(2.482)^{\star *}\end{array}$ & $\begin{array}{l}0.0918 \\
(2.787)^{\star \star \star}\end{array}$ & $\begin{array}{l}0.0987 \\
(2.565)^{\star *}\end{array}$ & $\begin{array}{l}0.0995 \\
(3.022)^{\star \star \star}\end{array}$ & $\begin{array}{l}0.0944 \\
(2.876)^{\star \star \star}\end{array}$ \\
\hline ROE & $\begin{array}{l}-0.0026 \\
(1.224)\end{array}$ & $\begin{array}{l}-0.0025 \\
(0.778)\end{array}$ & $\begin{array}{l}-0.0028 \\
(1.282)\end{array}$ & $\begin{array}{l}-0.0026 \\
(0.823)\end{array}$ & $\begin{array}{l}-0.0026 \\
(-1.219)\end{array}$ & $\begin{array}{l}-0.0026 \\
(1.202)\end{array}$ \\
\hline ROA & $\begin{array}{l}-0.1588 \\
(2.090)^{\star \star}\end{array}$ & $\begin{array}{l}-0.0887 \\
(0.986)\end{array}$ & $\begin{array}{l}-0.1417 \\
(1.874)^{\star}\end{array}$ & $\begin{array}{l}-0.0586 \\
(0.658)\end{array}$ & $\begin{array}{l}-0.2436 \\
(3.071)^{\star \star \star}\end{array}$ & $\begin{array}{l}-0.1663 \\
(2.201)^{\star \star}\end{array}$ \\
\hline $\mathrm{B} / \mathrm{M}$ ratio & $\begin{array}{l}0.0006 \\
(1.063)\end{array}$ & $\begin{array}{l}0.0004 \\
(0.565)\end{array}$ & $\begin{array}{l}0.0006 \\
(1.157)\end{array}$ & $\begin{array}{l}0.0004 \\
(0.598)\end{array}$ & $\begin{array}{l}0.0006 \\
(1.067)\end{array}$ & $\begin{array}{l}0.0006 \\
(1.112)\end{array}$ \\
\hline Cash holdings & $\begin{array}{l}0.1947 \\
(4.709)^{\star \star \star}\end{array}$ & $\begin{array}{l}0.0463 \\
(0.876)\end{array}$ & $\begin{array}{l}0.1907 \\
(4.617)^{\star \star \star}\end{array}$ & $\begin{array}{l}0.0416 \\
(0.787)\end{array}$ & $\begin{array}{l}0.1901 \\
(4.597)^{\star \star \star}\end{array}$ & $\begin{array}{l}0.1649 \\
(3.987)^{\star \star \star}\end{array}$ \\
\hline Profit & $\begin{array}{l}-0.0148 \\
(4.5611)^{\star * \star}\end{array}$ & $\begin{array}{l}-0.0148 \\
(4.215)^{\star \star *}\end{array}$ & $\begin{array}{l}-0.0147 \\
(4.530)^{\star * \star}\end{array}$ & $\begin{array}{l}0.0144 \\
(4.119)^{\star \star \star}\end{array}$ & $\begin{array}{l}0.0146 \\
(4.509)^{\star \star \star}\end{array}$ & $\begin{array}{l}-0.0133 \\
(4.096)^{\star * \star}\end{array}$ \\
\hline Sales growth & $\begin{array}{l}0.0547 \\
(2.851)^{\star \star \star}\end{array}$ & $\begin{array}{l}0.0290 \\
(1.093)\end{array}$ & $\begin{array}{l}0.0551 \\
(2.872)^{\star \star \star}\end{array}$ & $\begin{array}{l}0.0294 \\
(1.108)\end{array}$ & $\begin{array}{l}0.0549 \\
(2.860)^{\star \star \star}\end{array}$ & $\begin{array}{l}0.0536 \\
(2.803)^{\star \star \star}\end{array}$ \\
\hline $\begin{array}{l}\text { Hausman test statistic } \\
\text { (p-value) }\end{array}$ & $\begin{array}{l}19.949 \\
(0.173)\end{array}$ & $\begin{array}{l}23.298 \\
(0.056)^{\star \star}\end{array}$ & $\begin{array}{l}20.062 \\
(0.170)\end{array}$ & $\begin{array}{l}23.101 \\
(0.059)^{\star \star}\end{array}$ & $\begin{array}{l}19.191 \\
(0.205)\end{array}$ & $\begin{array}{l}18.581 \\
(0.233)\end{array}$ \\
\hline Industry dummies? & YES & YES & YES & YES & YES & YES \\
\hline $\mathrm{N}$ & 7615 & 5550 & 7615 & 5550 & 7615 & 7615 \\
\hline
\end{tabular}

Notes: absolute values of t-ratios in parentheses; $*, * *$ and $* * *$ denote significance at the $10 \%, 5 \%$ and $1 \%$ levels respectively. Profit coefficients are multiplied by 1000 for ease of presentation. 
Table 11 Random effects panel regressions of the effect of tax and other determinants on idiosyncratic risk

\begin{tabular}{|c|c|c|c|c|c|c|}
\hline \multirow[t]{2}{*}{ Independent variables } & \multicolumn{6}{|c|}{ Dependent variable: daily standard deviation of residuals from a CAPM regression } \\
\hline & CETR & CETR5 & GETR & GETR5 & BTD & PERM-BTD \\
\hline Tax measure & $\begin{array}{l}-0.0040 \\
(5.384)^{\star \star \star}\end{array}$ & $\begin{array}{l}-0.0006 \\
(0.643)\end{array}$ & $\begin{array}{l}-0.0008 \\
(0.832)\end{array}$ & $\begin{array}{l}-0.0060 \\
(4.674)^{\star \star \star}\end{array}$ & $\begin{array}{l}0.0091 \\
(7.598)^{\star \star \star}\end{array}$ & $\begin{array}{l}0.0094 \\
(3.244)^{\star \star \star}\end{array}$ \\
\hline Log(Market cap) & $\begin{array}{l}-0.0045 \\
(22.157)^{\star \star \star}\end{array}$ & $\begin{array}{l}-0.0059 \\
(23.590)^{\star * *}\end{array}$ & $\begin{array}{l}-0.0046 \\
(22.538)^{\star \star *}\end{array}$ & $\begin{array}{l}-0.0060 \\
(24.178)^{\star * \star}\end{array}$ & $\begin{array}{l}-0.0046 \\
(22.264)^{\star \star \star}\end{array}$ & $\begin{array}{l}-0.0046 \\
(22.458)^{\star \star \star}\end{array}$ \\
\hline Log(total assets) & $\begin{array}{l}0.0033 \\
(16.187)^{\star * *}\end{array}$ & $\begin{array}{l}0.0048 \\
(17.827)^{\star \star \star}\end{array}$ & $\begin{array}{l}0.0034 \\
(16.707)^{\star \star \star}\end{array}$ & $\begin{array}{l}0.0049 \\
(18.635)^{\star \star \star}\end{array}$ & $\begin{array}{l}0.0033 \\
(16.032)^{\star \star \star}\end{array}$ & $\begin{array}{l}0.0034 \\
(16.632)^{\star * *}\end{array}$ \\
\hline Intangible assets & $\begin{array}{l}0.0012 \\
(3.986)^{\star \star *}\end{array}$ & $\begin{array}{l}0.0016 \\
(2.819)^{\star \star \star}\end{array}$ & $\begin{array}{l}0.0012 \\
(4.154)^{\star \star \star}\end{array}$ & $\begin{array}{l}0.0017 \\
(3.020)^{\star \star \star}\end{array}$ & $\begin{array}{l}0.0012 \\
(4.072)^{\star * *}\end{array}$ & $\begin{array}{l}0.0013 \\
(4.513)^{\star \star \star}\end{array}$ \\
\hline Fixed assets & $\begin{array}{l}-0.0030 \\
(7.350)^{\star \star \star}\end{array}$ & $\begin{array}{l}-0.0035 \\
(5.263)^{\star \star \star}\end{array}$ & $\begin{array}{l}-0.0031 \\
(7.619)^{\star \star \star}\end{array}$ & $\begin{array}{l}-0.0033 \\
(5.128)^{\star \star \star}\end{array}$ & $\begin{array}{l}-0.0028 \\
(6.944)^{\star \star *}\end{array}$ & $\begin{array}{l}-0.0032 \\
(7.770)^{\star \star \star}\end{array}$ \\
\hline$R \& D$ expenditure & $\begin{array}{l}0.0121 \\
(4.150)^{\star \star \star}\end{array}$ & $\begin{array}{l}0.0167 \\
(3.533)^{\star \star \star}\end{array}$ & $\begin{array}{l}0.0123 \\
(4.222)^{\star \star \star}\end{array}$ & $\begin{array}{l}0.0183 \\
(3.885)^{\star \star \star}\end{array}$ & $\begin{array}{l}0.0119 \\
(4.073)^{\star \star \star}\end{array}$ & $\begin{array}{l}0.0119 \\
(4.055)^{\star \star \star}\end{array}$ \\
\hline $\mathrm{D} / \mathrm{E}$ ratio & $\begin{array}{l}-0.0404 \\
(1.342)\end{array}$ & $\begin{array}{l}-0.1300 \\
(1.343)\end{array}$ & $\begin{array}{l}-0.0452 \\
(1.501)\end{array}$ & $\begin{array}{l}-0.1166 \\
(1.207)\end{array}$ & $\begin{array}{l}-0.0423 \\
(1.410)\end{array}$ & $\begin{array}{l}-0.0448 \\
(1.489)\end{array}$ \\
\hline Leverage & $\begin{array}{l}0.0031 \\
(4.610)^{\star \star *}\end{array}$ & $\begin{array}{l}0.0048 \\
(5.043)^{\star \star *}\end{array}$ & $\begin{array}{l}0.0033 \\
(5.029)^{\star * *}\end{array}$ & $\begin{array}{l}0.0048 \\
(5.127)^{\star \star * *}\end{array}$ & $\begin{array}{l}0.0032 \\
(4.879)^{\star \star *}\end{array}$ & $\begin{array}{l}0.0033 \\
(4.983)^{\star * *}\end{array}$ \\
\hline ROE & $\begin{array}{l}-0.0488 \\
(-0.620)\end{array}$ & $\begin{array}{l}-0.0867 \\
(1.056)\end{array}$ & $\begin{array}{l}-0.0492 \\
(0.624)\end{array}$ & $\begin{array}{l}-0.0722 \\
(0.883)\end{array}$ & $\begin{array}{l}-0.0357 \\
(0.454)\end{array}$ & $\begin{array}{l}-0.0454 \\
(0.576)\end{array}$ \\
\hline ROA & $\begin{array}{l}0.0112 \\
(7.270)^{\star \star \star}\end{array}$ & $\begin{array}{l}0.0188 \\
(8.399)^{\star \star \star}\end{array}$ & $\begin{array}{l}0.0118 \\
(7.682)^{\star \star \star}\end{array}$ & $\begin{array}{l}0.0201 \\
(9.124)^{\star \star *}\end{array}$ & $\begin{array}{l}0.0083 \\
(5.203)^{\star \star \star}\end{array}$ & $\begin{array}{l}0.0113 \\
(7.331)^{\star \star *}\end{array}$ \\
\hline $\mathrm{B} / \mathrm{M}$ ratio & $\begin{array}{l}0.0134 \\
(0.716)\end{array}$ & $\begin{array}{l}0.0254 \\
(1.305)\end{array}$ & $\begin{array}{l}0.0136 \\
(0.726)\end{array}$ & $\begin{array}{l}0.0220 \\
(1.137)\end{array}$ & $\begin{array}{l}0.0105 \\
(0.560)\end{array}$ & $\begin{array}{l}0.0130 \\
(0.691)\end{array}$ \\
\hline Cash holdings & $\begin{array}{l}0.0018 \\
(3.254)^{\star \star *}\end{array}$ & $\begin{array}{l}0.0021 \\
(1.586)\end{array}$ & $\begin{array}{l}0.0018 \\
(3.214)^{\star \star \star}\end{array}$ & $\begin{array}{l}0.0021 \\
(1.585)\end{array}$ & $\begin{array}{l}0.0018 \\
(3.207)^{\star \star \star}\end{array}$ & $\begin{array}{l}0.0016 \\
(2.870)^{\star \star \star}\end{array}$ \\
\hline Profit & $\begin{array}{l}-0.0003 \\
(3.604)^{\star \star \star}\end{array}$ & $\begin{array}{l}-0.0003 \\
(4.356)^{\star \star \star}\end{array}$ & $\begin{array}{l}-0.0003 \\
(3.635)^{\star \star \star}\end{array}$ & $\begin{array}{l}-0.0004 \\
(4.453)^{\star \star \star}\end{array}$ & $\begin{array}{l}-0.0003 \\
(3.531)^{\star \star \star}\end{array}$ & $\begin{array}{l}-0.0003 \\
(3.436)^{\star \star \star}\end{array}$ \\
\hline Sales growth & $\begin{array}{l}-0.0003 \\
(4.032)^{\star \star \star}\end{array}$ & $\begin{array}{l}-0.0004 \\
(0.624)\end{array}$ & $\begin{array}{l}-0.0003 \\
(4.093)^{\star \star \star}\end{array}$ & $\begin{array}{l}-0.0004 \\
(0.627)\end{array}$ & $\begin{array}{l}-0.0003 \\
(3.644)^{\star \star \star}\end{array}$ & $\begin{array}{l}-0.0003 \\
(3.725)^{\star \star \star}\end{array}$ \\
\hline $\begin{array}{l}\text { Hausman test statistic } \\
\text { (p-value) }\end{array}$ & $\begin{array}{l}14.731 \\
(0.471)\end{array}$ & $\begin{array}{l}16.802 \\
(0.267)\end{array}$ & $\begin{array}{l}14.519 \\
(0.487)\end{array}$ & $\begin{array}{l}16.877 \\
(0.263)\end{array}$ & $\begin{array}{l}14.297 \\
(0.503)\end{array}$ & $\begin{array}{l}14.072 \\
(0.520)\end{array}$ \\
\hline Industry dummies? & YES & YES & YES & YES & YES & YES \\
\hline $\mathrm{N}$ & 7668 & 5306 & 7668 & 5306 & 7669 & 7669 \\
\hline
\end{tabular}

Notes: absolute values of t-ratios in parentheses; *, ** and *** denote significance at the $10 \%, 5 \%$ and $1 \%$ levels respectively. D/E ratio, ROE, B/M ratio, and profit coefficients are multiplied by 1000 for ease of presentation. 
Table 12 Average abnormal returns and cumulative abnormal returns (\%) for firms whose names appear in the media in a tax-related story

\begin{tabular}{|c|c|c|c|c|c|c|c|c|c|c|c|c|}
\hline & All firms & Big firms & Small firms & $\begin{array}{l}\text { Potentially } \\
\text { culpable } \\
\text { stories }\end{array}$ & $\begin{array}{l}\text { General } \\
\text { stories }\end{array}$ & $\begin{array}{l}\text { Corporate } \\
\text { Inversion }\end{array}$ & $\begin{array}{l}\text { Regional } \\
\text { newspapers }\end{array}$ & $\begin{array}{l}\text { National } \\
\text { newspapers }\end{array}$ & $\begin{array}{l}\text { Foreign } \\
\text { newspapers }\end{array}$ & $\begin{array}{l}\text { Specialist } \\
\text { financial } \\
\text { newspapers }\end{array}$ & $\begin{array}{l}\text { Consumer- } \\
\text { facing firms }\end{array}$ & $\begin{array}{l}\text { Non- } \\
\text { consumer- } \\
\text { facing firms }\end{array}$ \\
\hline Number of firms & 237 & 208 & 29 & 78 & 132 & 100 & 15 & 181 & 12 & 29 & 93 & 144 \\
\hline $\operatorname{CAR}(-30,-10)$ & $\begin{array}{l}-0.861 \\
(1.364)\end{array}$ & $\begin{array}{l}-0.531 \\
(0.811)\end{array}$ & $\begin{array}{l}-3.223 \\
(1.522)\end{array}$ & $\begin{array}{l}-0.790 \\
(0.881)\end{array}$ & $\begin{array}{l}-0.807 \\
(0.858)\end{array}$ & $\begin{array}{l}1.361 \\
(0.676)\end{array}$ & $\begin{array}{l}-2.975 \\
(1.227)\end{array}$ & $\begin{array}{l}-1.077 \\
(1.438)\end{array}$ & $\begin{array}{l}3.055 \\
(1.794)^{*}\end{array}$ & $\begin{array}{l}-0.034 \\
(0.021)\end{array}$ & $\begin{array}{l}-0.322 \\
(1.557)\end{array}$ & $\begin{array}{l}-0.563 \\
(0.638)\end{array}$ \\
\hline $\operatorname{CAR}(-10,-1)$ & $\begin{array}{l}-0.057 \\
(0.131)\end{array}$ & $\begin{array}{l}0.239 \\
(0.529)\end{array}$ & $\begin{array}{l}-2.180 \\
(1.492)\end{array}$ & $\begin{array}{l}-0.419 \\
(0.677)\end{array}$ & $\begin{array}{l}0.511 \\
(0.787)\end{array}$ & $\begin{array}{l}0.073 \\
(0.052)\end{array}$ & $\begin{array}{l}-0.461 \\
(0.276)\end{array}$ & $\begin{array}{l}-0.238 \\
(0.461)\end{array}$ & $\begin{array}{l}2.210 \\
(1.882)^{\star}\end{array}$ & $\begin{array}{l}0.345 \\
(0.307)\end{array}$ & $\begin{array}{l}-0.131 \\
(0.223)\end{array}$ & $\begin{array}{l}0.009 \\
(0.015)\end{array}$ \\
\hline AR - Day 0 & $\begin{array}{l}-0.200 \\
(1.452)\end{array}$ & $\begin{array}{l}-0.123 \\
(0.864)\end{array}$ & $\begin{array}{l}-0.747 \\
(1.617)\end{array}$ & $\begin{array}{l}-0.098 \\
(0.498)\end{array}$ & $\begin{array}{l}-0.214 \\
(1.044)\end{array}$ & $\begin{array}{l}-0.659 \\
(1.500)\end{array}$ & $\begin{array}{l}0.442 \\
(0.836)\end{array}$ & $\begin{array}{l}-0.197 \\
(1.204)\end{array}$ & $\begin{array}{l}-0.578 \\
(1.555)\end{array}$ & $\begin{array}{l}-0.394 \\
(1.111)\end{array}$ & $\begin{array}{l}-0.226 \\
(1.218)\end{array}$ & $\begin{array}{l}-0.183 \\
(0.952)\end{array}$ \\
\hline $\operatorname{CAR}(+1,+10)$ & $\begin{array}{l}0.403 \\
(0.926)\end{array}$ & $\begin{array}{l}0.378 \\
(0.835)\end{array}$ & $\begin{array}{l}0.585 \\
(0.401)\end{array}$ & $\begin{array}{l}0.960 \\
(1.550)\end{array}$ & $\begin{array}{l}-0.294 \\
(0.453)\end{array}$ & $\begin{array}{l}-0.304 \\
(0.219)\end{array}$ & $\begin{array}{l}2.941 \\
(1.758)^{*}\end{array}$ & $\begin{array}{l}0.447 \\
(0.865)\end{array}$ & $\begin{array}{l}-1.609 \\
(1.370)\end{array}$ & $\begin{array}{l}-0.352 \\
(0.314)\end{array}$ & $\begin{array}{l}0.796 \\
(1.359)\end{array}$ & $\begin{array}{l}0.149 \\
(0.245)\end{array}$ \\
\hline $\operatorname{CAR}(+10,+30)$ & $\begin{array}{l}0.177 \\
(0.280)\end{array}$ & $\begin{array}{l}0.138 \\
(0.210)\end{array}$ & $\begin{array}{l}0.456 \\
(0.215)\end{array}$ & $\begin{array}{l}0.196 \\
(0.219)\end{array}$ & $\begin{array}{l}0.347 \\
(0.367)\end{array}$ & $\begin{array}{l}-0.391 \\
(0.194)\end{array}$ & $\begin{array}{l}-0.961 \\
(0.396)\end{array}$ & $\begin{array}{l}0.243 \\
(0.323)\end{array}$ & $\begin{array}{l}2.581 \\
(1.516)\end{array}$ & $\begin{array}{l}-0.635 \\
(0.390)\end{array}$ & $\begin{array}{l}-0.807 \\
(0.950)\end{array}$ & $\begin{array}{l}0.818 \\
(0.924)\end{array}$ \\
\hline $\operatorname{CAR}(-3,+3)$ & $\begin{array}{l}-0.024 \\
(0.067)\end{array}$ & $\begin{array}{l}0.179 \\
(0.474)\end{array}$ & $\begin{array}{l}-1.484 \\
(1.214)\end{array}$ & $\begin{array}{l}0.103 \\
(0.199)\end{array}$ & $\begin{array}{l}0.059 \\
(0.109)\end{array}$ & $\begin{array}{l}-0.888 \\
(0.764)\end{array}$ & $\begin{array}{l}0.897 \\
(0.641)\end{array}$ & $\begin{array}{l}0.053 \\
(0.122)\end{array}$ & $\begin{array}{l}-0.591 \\
(0.602)\end{array}$ & $\begin{array}{l}-0.748 \\
(0.796)\end{array}$ & $\begin{array}{l}0.498 \\
(1.016)\end{array}$ & $\begin{array}{l}-0.362 \\
(0.710)\end{array}$ \\
\hline
\end{tabular}

Notes: absolute values of t-ratios in parentheses; *, ** and *** denote significance at the $10 \%, 5 \%$ and $1 \%$ levels respectively. 
Table 13 Volume ratios on days around tax news announcements for various groups of firms

\begin{tabular}{|c|c|c|c|c|c|c|c|c|c|c|c|c|}
\hline \multirow[t]{2}{*}{ Day } & \multicolumn{2}{|l|}{ All } & \multicolumn{2}{|c|}{ Small firms } & \multicolumn{2}{|c|}{ Big firms } & \multicolumn{2}{|c|}{ Culpable } & \multicolumn{2}{|c|}{ Not culpable } & \multicolumn{2}{|c|}{ Expatriations } \\
\hline & Ratio & t-ratio & Ratio & t-ratio & Ratio & t-ratio & Ratio & t-ratio & Ratio & t-ratio & Ratio & t-ratio \\
\hline-5 & 0.968 & -1.064 & 0.779 & $-2.410^{\star \star *}$ & 0.996 & -0.130 & 1.011 & 0.181 & 0.935 & $-1.850^{*}$ & 1.015 & 0.170 \\
\hline-4 & 1.048 & 1.369 & 0.881 & -0.798 & 1.071 & $2.084^{\star *}$ & 1.137 & $2.106^{\star *}$ & 1.002 & 0.043 & 1.017 & 0.164 \\
\hline-3 & 1.064 & 1.364 & 1.245 & 0.808 & 1.039 & 1.152 & 1.172 & $2.134^{\star *}$ & 0.962 & -0.714 & 1.258 & 1.183 \\
\hline-2 & 1.127 & $2.111^{\star *}$ & 1.411 & 1.199 & 1.089 & $1.764^{*}$ & 1.259 & $2.273^{\star *}$ & 1.017 & 0.253 & 1.288 & 1.157 \\
\hline-1 & 1.167 & $2.931^{\star \star \star}$ & 1.421 & $1.670^{*}$ & 1.131 & $2.414^{\star \star}$ & 1.205 & $2.211^{\star *}$ & 1.023 & 0.374 & 1.754 & $2.780^{\star \star \star}$ \\
\hline 0 & 1.205 & $2.713^{\star \star \star}$ & 1.506 & 1.513 & 1.164 & $2.254^{\star *}$ & 1.232 & $1.736^{*}$ & 1.057 & 0.684 & 1.844 & $2.573^{\star \star *}$ \\
\hline 1 & 1.083 & 1.737 & 1.097 & 0.599 & 1.081 & 1.631 & 1.114 & 1.398 & 0.990 & -0.192 & 1.448 & $2.046^{* *}$ \\
\hline 2 & 1.151 & $3.235^{\star \star \star}$ & 1.049 & 0.290 & 1.165 & $3.461^{\star \star *}$ & 1.149 & $2.034^{\star *}$ & 1.127 & $1.851^{*}$ & 1.270 & $2.693^{* \star *}$ \\
\hline 3 & 1.125 & $2.691^{* * *}$ & 1.336 & $1.652^{\star}$ & 1.095 & $2.141^{\star \star}$ & 1.034 & 0.516 & 1.122 & $1.820^{*}$ & 1.389 & $2.871^{\star \star \star}$ \\
\hline 4 & 1.120 & $2.618^{\star \star \star \star}$ & 1.229 & 1.099 & 1.105 & $2.411^{\star \star}$ & 1.108 & 1.350 & 1.083 & 1.320 & 1.337 & $2.703^{\star \star \star}$ \\
\hline 5 & 1.032 & 0.917 & 1.165 & 1.064 & 1.012 & 0.380 & 1.036 & 0.655 & 0.957 & -0.989 & 1.375 & $2.799^{\star \star \star}$ \\
\hline 6 & 0.997 & -0.086 & 0.884 & -1.008 & 1.013 & 0.402 & 0.985 & -0.293 & 0.989 & -0.267 & 1.072 & 0.664 \\
\hline 7 & 1.007 & 0.198 & 0.904 & -0.699 & 1.022 & 0.629 & 1.064 & 1.161 & 0.920 & $-1.819^{*}$ & 1.287 & $2.347^{\star \star}$ \\
\hline 8 & 1.229 & $3.232^{\star \star \star}$ & 1.690 & $1.777^{\star}$ & 1.164 & $2.790^{\star \star \star}$ & 1.167 & $2.056^{\star \star}$ & 1.176 & $1.862^{*}$ & 1.660 & $1.993^{\star \star}$ \\
\hline 9 & 1.145 & $2.837^{\star \star \star}$ & 1.270 & 1.110 & 1.127 & $2.684^{\star \star \star}$ & 1.157 & $2.144^{\star \star}$ & 1.101 & 1.461 & 1.324 & 1.586 \\
\hline 10 & 1.153 & $2.543^{\star * *}$ & 1.758 & $1.974^{* *}$ & 1.070 & $1.693^{*}$ & 1.180 & $1.826^{*}$ & 1.095 & 1.178 & 1.368 & $1.755^{*}$ \\
\hline
\end{tabular}

Note: this table presents the trading volumes on each day in the event window as ratios of their average pre-event values with $\mathrm{t}$-ratios in the right-hand columns; $* * *$ and $* * *$ denote significance at the $10 \%, 5 \%$ and $1 \%$ levels. 
Table 14 Multiple regressions to evaluate the impact of various factors on cumulative abnormal returns around the occurrence of a tax-related news story

\begin{tabular}{|c|c|c|c|c|c|c|c|c|c|c|c|c|c|}
\hline & Intercept & CAPM beta & Tax measure & $\mathrm{B} / \mathrm{M}$ ratio & $\begin{array}{l}\text { Log } \\
\text { (market cap) }\end{array}$ & $\begin{array}{l}\text { Excess return } \\
\text { over prior year }\end{array}$ & $\begin{array}{l}\text { Idiosyncratic } \\
\text { volatility }\end{array}$ & Culpability & $\begin{array}{l}\text { Consumer- } \\
\text { facing }\end{array}$ & $\begin{array}{l}\text { Specialist } \\
\text { financial }\end{array}$ & Post-2011 & Expatriation & $\mathrm{R}^{2}$ \\
\hline \multicolumn{14}{|c|}{ Panel A: tax variable is CETR } \\
\hline $\operatorname{CAR}(-30,-10)$ & $\begin{array}{l}-0.0824^{\star \star *} \\
(-2.455)\end{array}$ & $\begin{array}{l}-0.0104 \\
(-0.526)\end{array}$ & $\begin{array}{l}-0.0107^{* \star *} \\
(-0.270)\end{array}$ & $\begin{array}{l}0.0042 \\
(0.387)\end{array}$ & $\begin{array}{l}0.0602 \\
(2.423)\end{array}$ & $\begin{array}{l}0.0233 \\
(1.028)\end{array}$ & $\begin{array}{l}1.7499^{\star \star \star} \\
(2.171)\end{array}$ & $\begin{array}{l}0.0081 \\
(0.488)\end{array}$ & $\begin{array}{l}-0.0025 \\
(-0.148)\end{array}$ & $\begin{array}{l}0.0163 \\
(0.712)\end{array}$ & $\begin{array}{l}-0.0228^{\star \star \star} \\
(-1.128)\end{array}$ & $\begin{array}{l}-0.0154^{\star \star \star} \\
(-0.433)\end{array}$ & $5.2 \%$ \\
\hline $\operatorname{CAR}(-10,-1)$ & $\begin{array}{l}-0.0295^{\star \star *} \\
(-1.234)\end{array}$ & $\begin{array}{l}0.0054 \\
(0.382)\end{array}$ & $\begin{array}{l}-0.0307 \\
(-1.093)\end{array}$ & $\begin{array}{l}0.0128^{\star * *} \\
(1.656)\end{array}$ & $\begin{array}{l}0.0109 \\
(0.619)\end{array}$ & $\begin{array}{l}0.0278 \\
(1.726)\end{array}$ & $\begin{array}{l}-0.4631 \\
(-0.808)\end{array}$ & $\begin{array}{l}0.0252 \\
(2.131)\end{array}$ & $\begin{array}{l}0.0145 \\
(1.185)\end{array}$ & $\begin{array}{l}0.0152^{\star * *} \\
(0.929)\end{array}$ & $\begin{array}{l}-0.0023 \\
(-0.158)\end{array}$ & $\begin{array}{l}-0.0315^{\star \star \star} \\
(-1.243)\end{array}$ & $8.8 \%$ \\
\hline AR - Day 0 & $\begin{array}{l}-0.0180^{* \star *} \\
(-1.709)\end{array}$ & $\begin{array}{l}0.0052 \\
(0.845)\end{array}$ & $\begin{array}{l}0.0044^{\star \star \star} \\
(0.352)\end{array}$ & $\begin{array}{l}-0.0046^{* * *} \\
(-1.350)\end{array}$ & $\begin{array}{l}0.0048 \\
(0.612)\end{array}$ & $\begin{array}{l}0.0155 \\
(2.173)\end{array}$ & $\begin{array}{l}0.3430 \\
(1.356)\end{array}$ & $\begin{array}{l}0.0007^{\star \star \star} \\
(0.137)\end{array}$ & $\begin{array}{l}0.0021 \\
(0.395)\end{array}$ & $\begin{array}{l}-0.0006^{\star \star *} \\
(-0.087)\end{array}$ & $\begin{array}{l}0.0028^{\star * *} \\
(0.446)\end{array}$ & $\begin{array}{l}-0.0043^{\star \star \star} \\
(-0.386)\end{array}$ & $4.20 \%$ \\
\hline $\operatorname{CAR}(+1,+10)$ & $\begin{array}{l}-0.0732^{* * *} \\
(-3.140)\end{array}$ & $\begin{array}{l}0.0030^{\star \star *} \\
(0.221)\end{array}$ & $\begin{array}{l}-0.0275^{* \star *} \\
(-1.002)\end{array}$ & $\begin{array}{l}-0.0007 \\
(-0.093)\end{array}$ & $\begin{array}{l}0.0362 \\
(2.099)\end{array}$ & $\begin{array}{l}0.0127^{\star \star *} \\
(0.808)\end{array}$ & $\begin{array}{l}2.8337 \\
(5.067)\end{array}$ & $\begin{array}{l}-0.0056 \\
(-0.486)\end{array}$ & $\begin{array}{l}0.0120^{\star \star *} \\
(1.003)\end{array}$ & $\begin{array}{l}-0.0005^{* * *} \\
(-0.034)\end{array}$ & $\begin{array}{l}-0.0034 \\
(-0.245)\end{array}$ & $\begin{array}{l}-0.0092^{\star \star *} \\
(-0.372)\end{array}$ & $15.4 \%$ \\
\hline $\operatorname{CAR}(+10,+30)$ & $\begin{array}{l}-0.0325^{\star \star *} \\
(-1.041)\end{array}$ & $\begin{array}{l}-0.0115 \\
(-0.628)\end{array}$ & $\begin{array}{l}-0.0190^{* * *} \\
(-0.519)\end{array}$ & $\begin{array}{l}0.0105^{\star * *} \\
(1.034)\end{array}$ & $\begin{array}{l}0.0429 \\
(1.857)\end{array}$ & $\begin{array}{l}-0.0836 \\
(-3.964)\end{array}$ & $\begin{array}{l}1.3072 \\
(1.744)\end{array}$ & $\begin{array}{l}0.0107 \\
(0.693)\end{array}$ & $\begin{array}{l}-0.0143 \\
(-0.889)\end{array}$ & $\begin{array}{l}-0.0225 \\
(-1.055)\end{array}$ & $\begin{array}{l}0.0027 \\
(0.143)\end{array}$ & $\begin{array}{l}-0.0496^{* \star \star} \\
(-1.497)\end{array}$ & $15.7 \%$ \\
\hline $\operatorname{CAR}(-3,+3)$ & $\begin{array}{l}-0.0785^{* \star *} \\
(-3.423)\end{array}$ & $\begin{array}{l}0.0137^{\star \star *} \\
(1.014)\end{array}$ & $\begin{array}{l}-0.0129 \\
(-0.477)\end{array}$ & $\begin{array}{l}-0.0017 \\
(-0.230)\end{array}$ & $\begin{array}{l}0.0211 \\
(1.242)\end{array}$ & $\begin{array}{l}0.0504 \\
(3.256)\end{array}$ & $\begin{array}{l}2.0528 \\
(3.729)\end{array}$ & $\begin{array}{l}0.0058 \\
(0.510)\end{array}$ & $\begin{array}{l}0.0195^{\star \star \star *} \\
(1.657)\end{array}$ & $\begin{array}{l}0.0117 \\
(0.745)\end{array}$ & $\begin{array}{l}0.0027^{\star \star \star} \\
(0.198)\end{array}$ & $\begin{array}{l}-0.0094^{\star \star \star} \\
(-0.385)\end{array}$ & $10.6 \%$ \\
\hline \multicolumn{14}{|c|}{ Panel $B:$ tax variable is GETR } \\
\hline $\operatorname{CAR}(-30,-10)$ & $\begin{array}{l}-0.0902^{\star \star *} \\
(-2.600)\end{array}$ & $\begin{array}{l}-0.0091 \\
(-0.472)\end{array}$ & $\begin{array}{l}0.0361^{* * *} \\
(0.718)\end{array}$ & $\begin{array}{l}0.0050 \\
(0.462)\end{array}$ & $\begin{array}{l}0.0571 \\
(2.408)\end{array}$ & $\begin{array}{l}0.0207 \\
(0.939)\end{array}$ & $\begin{array}{l}1.6979^{\star \star \star} \\
(2.227)\end{array}$ & $\begin{array}{l}0.0080 \\
(0.489)\end{array}$ & $\begin{array}{l}-0.0029 \\
(-0.172)\end{array}$ & $\begin{array}{l}0.0183 \\
(0.823)\end{array}$ & $\begin{array}{l}-0.0222^{\star \star *} \\
(-1.116)\end{array}$ & $\begin{array}{l}-0.0127^{\star \star \star} \\
(-0.369)\end{array}$ & $5.4 \%$ \\
\hline $\operatorname{CAR}(-10,-1)$ & $\begin{array}{l}-0.0113^{* \star *} \\
(-0.451)\end{array}$ & $\begin{array}{l}0.0055 \\
(0.395)\end{array}$ & $\begin{array}{l}-0.0889 \\
(-2.442)\end{array}$ & $\begin{array}{l}0.0137^{\star \star *} \\
(1.758)\end{array}$ & $\begin{array}{l}0.0084 \\
(0.489)\end{array}$ & $\begin{array}{l}0.0269 \\
(1.680)\end{array}$ & $\begin{array}{l}-0.7902 \\
(-1.430)\end{array}$ & $\begin{array}{l}0.0292 \\
(2.465)\end{array}$ & $\begin{array}{l}0.0169 \\
(1.385)\end{array}$ & $\begin{array}{l}0.0194^{*} \\
(1.203)\end{array}$ & $\begin{array}{l}-0.0016 \\
(-0.114)\end{array}$ & $\begin{array}{l}-0.0314^{\star \star \star} \\
(-1.263)\end{array}$ & $11.8 \%$ \\
\hline AR - Day 0 & $\begin{array}{l}-0.0233^{\star \star *} \\
(-2.152)\end{array}$ & $\begin{array}{l}0.0061 \\
(1.018)\end{array}$ & $\begin{array}{l}0.0282^{\star \star \star} \\
(1.799)\end{array}$ & $\begin{array}{l}-0.0044^{* \star *} \\
(-1.323)\end{array}$ & $\begin{array}{l}0.0039 \\
(0.530)\end{array}$ & $\begin{array}{l}0.0132 \\
(1.917)\end{array}$ & $\begin{array}{l}0.3178 \\
(1.334)\end{array}$ & $\begin{array}{l}0.0010^{\star \star *} \\
(0.189)\end{array}$ & $\begin{array}{l}0.0021 \\
(0.393)\end{array}$ & $\begin{array}{l}0.0004^{* * \star} \\
(0.054)\end{array}$ & $\begin{array}{l}0.0025^{\star \star \star} \\
(0.394)\end{array}$ & $\begin{array}{l}-0.0058^{\star \star \star} \\
(-0.545)\end{array}$ & $5.2 \%$ \\
\hline $\operatorname{CAR}(+1,+10)$ & $\begin{array}{l}-0.0559^{* \star *} \\
(-2.284)\end{array}$ & $\begin{array}{l}0.0016^{\star \star \star} \\
(0.120)\end{array}$ & $\begin{array}{l}-0.0328 \\
(-0.924)\end{array}$ & $\begin{array}{l}-0.0009 \\
(-0.114)\end{array}$ & $\begin{array}{l}0.0287 \\
(1.717)\end{array}$ & $\begin{array}{l}0.0069^{\star \star \star} \\
(0.443)\end{array}$ & $\begin{array}{l}2.5146 \\
(4.675)\end{array}$ & $\begin{array}{l}-0.0037 \\
(-0.320)\end{array}$ & $\begin{array}{l}0.0115^{\star \star \star} \\
(0.965)\end{array}$ & $\begin{array}{l}-0.0025^{* \star *} \\
(-0.160)\end{array}$ & $\begin{array}{l}-0.0025 \\
(-0.180)\end{array}$ & $\begin{array}{l}-0.0175^{\star \star \star} \\
(-0.724)\end{array}$ & $14.0 \%$ \\
\hline $\operatorname{CAR}(+10,+30)$ & $\begin{array}{l}-0.0343^{\star \star *} \\
(-1.047)\end{array}$ & $\begin{array}{l}-0.0119 \\
(-0.653)\end{array}$ & $\begin{array}{l}0.0184^{\star \star *} \\
(0.388)\end{array}$ & $\begin{array}{l}0.0126^{\star \star *} \\
(1.246)\end{array}$ & $\begin{array}{l}0.0368 \\
(1.644)\end{array}$ & $\begin{array}{l}-0.0890 \\
(-4.266)\end{array}$ & $\begin{array}{l}1.0601 \\
(1.472)\end{array}$ & $\begin{array}{l}0.0154 \\
(1.002)\end{array}$ & $\begin{array}{l}-0.0133 \\
(-0.836)\end{array}$ & $\begin{array}{l}-0.0130 \\
(-0.617)\end{array}$ & $\begin{array}{l}0.0020 \\
(0.104)\end{array}$ & $\begin{array}{l}-0.0535^{\star \star \star} \\
(-1.651)\end{array}$ & $14.85 \%$ \\
\hline $\operatorname{CAR}(-3,+3)$ & $\begin{array}{l}-0.0734^{* *} \\
(-3.087)\end{array}$ & $\begin{array}{l}0.0149^{* *} \\
(1.130)\end{array}$ & $\begin{array}{l}-0.0376^{\star * *} \\
(-1.092)\end{array}$ & $\begin{array}{l}-0.0023 \\
(-0.316)\end{array}$ & $\begin{array}{l}0.0243 \\
(1.493)\end{array}$ & $\begin{array}{l}0.0471 \\
(3.113)\end{array}$ & $\begin{array}{l}1.8039 \\
(3.450)\end{array}$ & $\begin{array}{l}0.0078 \\
(0.698)\end{array}$ & $\begin{array}{l}0.0222 \\
(1.920)\end{array}$ & $\begin{array}{l}0.0091 \\
(0.596)\end{array}$ & $\begin{array}{l}0.0033 \\
(0.245)\end{array}$ & $\begin{array}{l}-0.0160 \\
(-0.680)\end{array}$ & $10.65 \%$ \\
\hline
\end{tabular}

Notes: absolute values of t-ratios in parentheses; * ** and *** denote significance at the $10 \%, 5 \%$ and $1 \%$ levels respectively. 
Figure 1 Cumulative abnormal returns for all firms subject to tax-related news stories

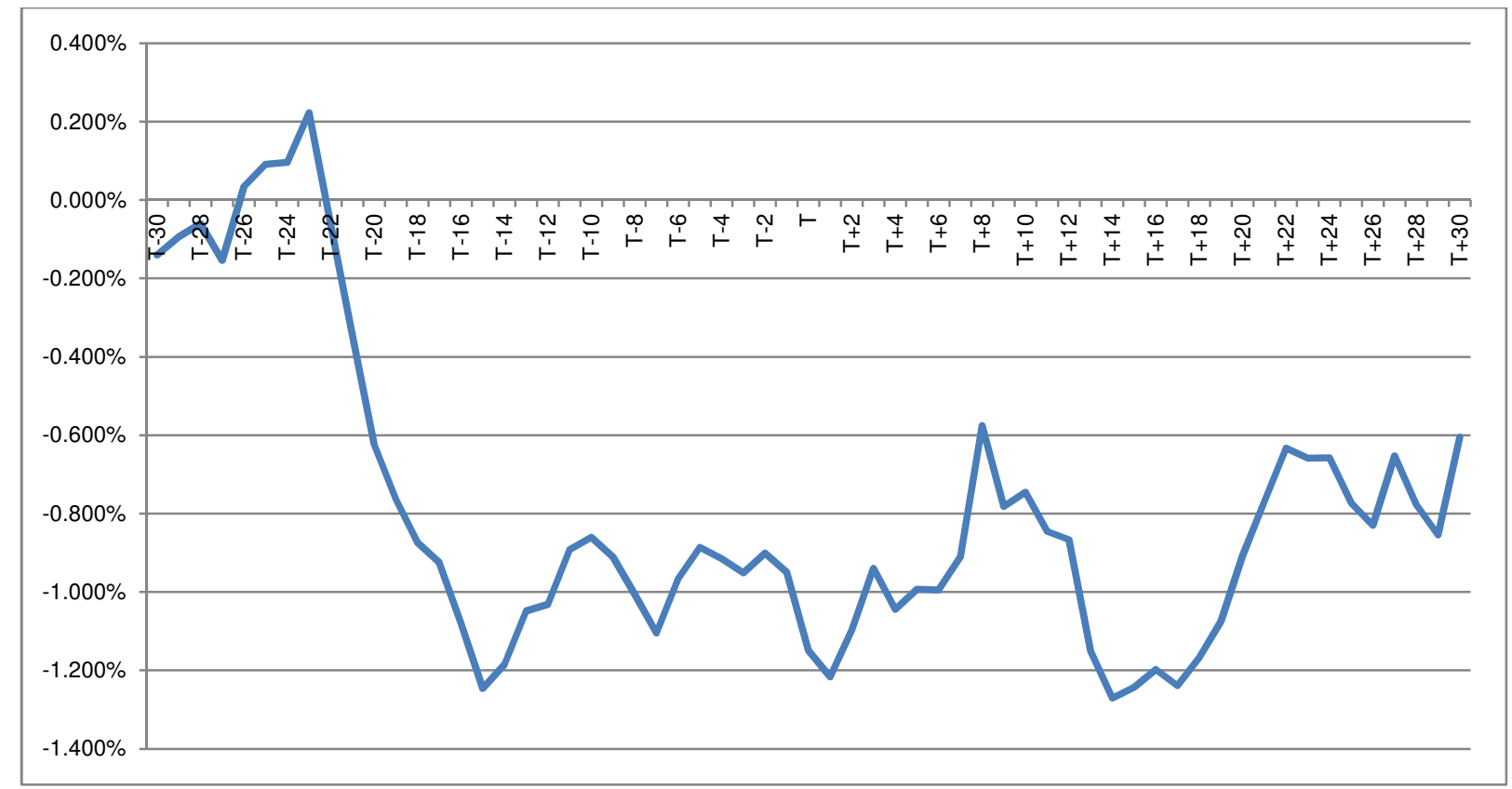

Figure 2 Cumulative abnormal returns for small versus big firms subject to tax-related news stories

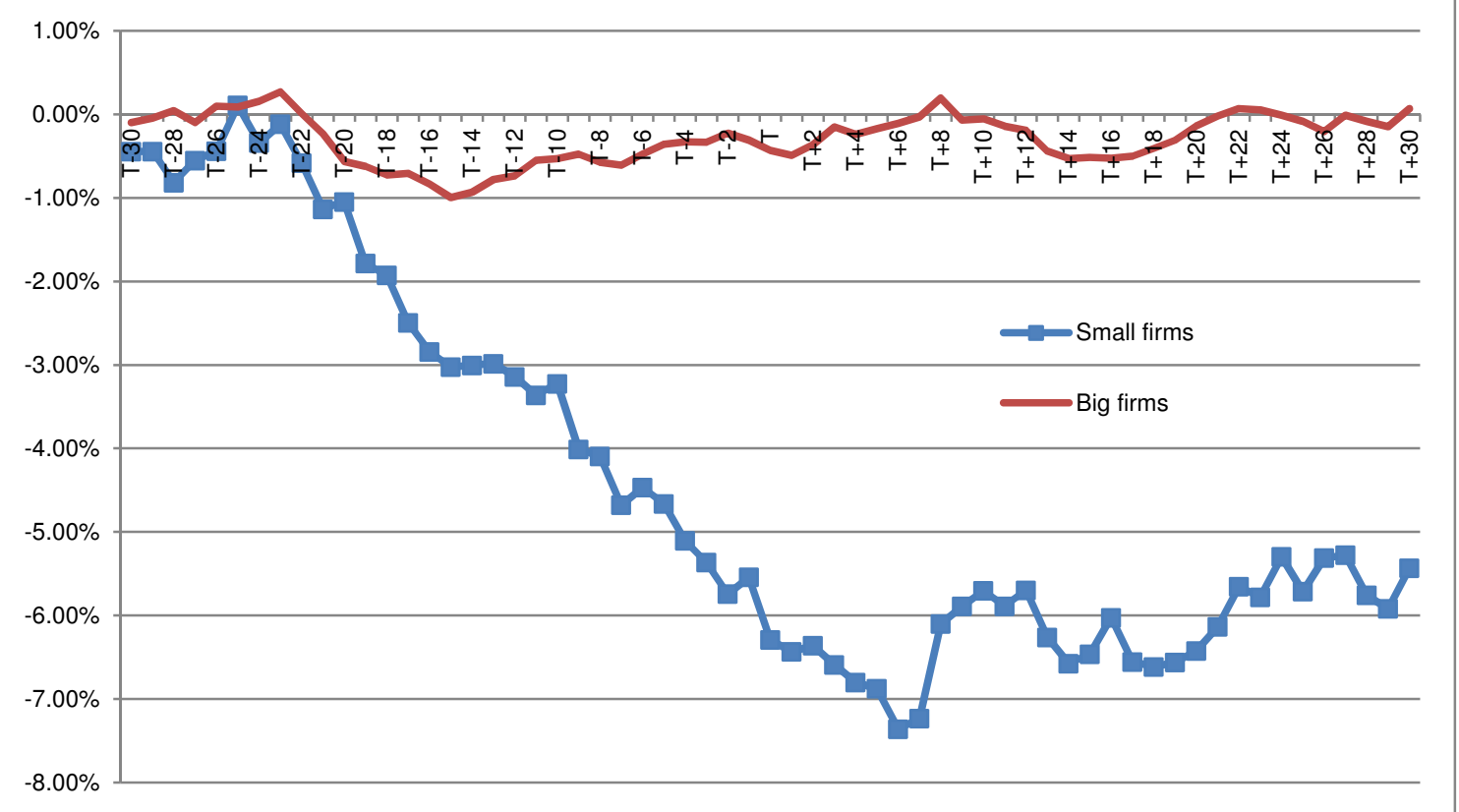


Figure 3 Cumulative abnormal returns for firms subject to tax-related news where the stories relate to potentially serious issues where firms may be culpable versus more general stories and where possible corporate inversions are mentioned

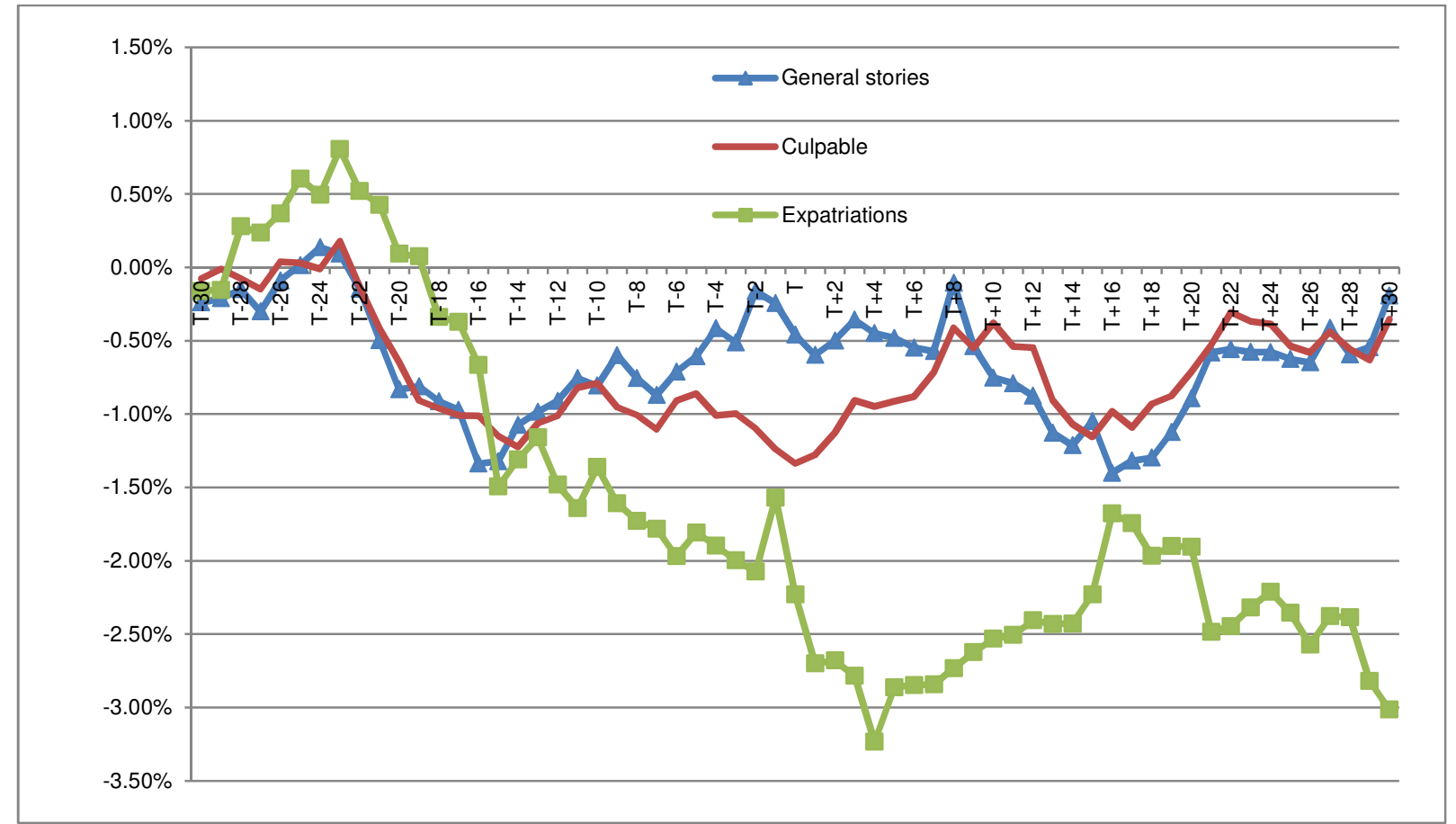

Figure 4 Cumulative abnormal returns for consumer-facing versus non-consumer-facing firms subject to tax-related news stories

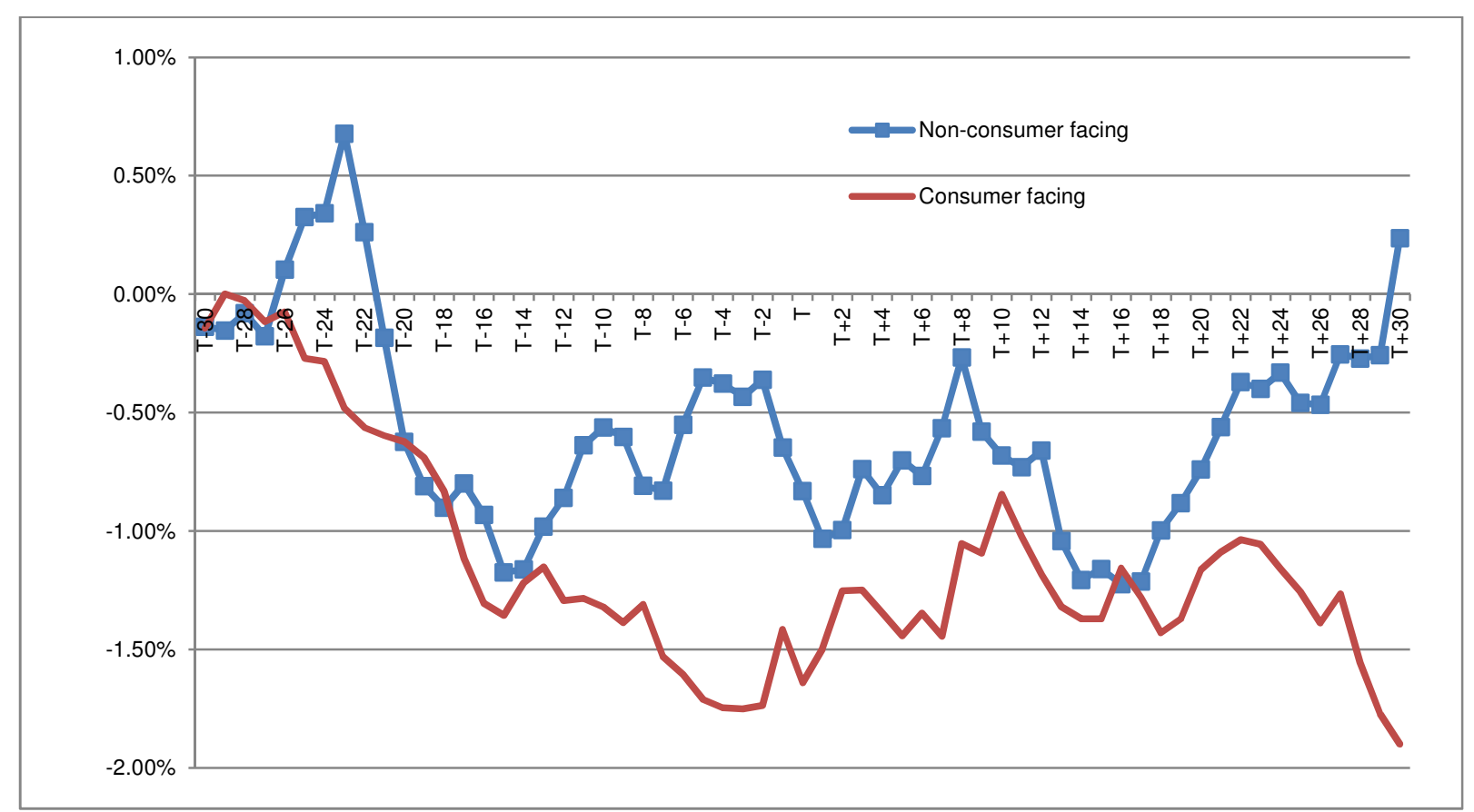


Figure 5 Turnover Ratios for Large and Small Firms around a Tax-Related News Event

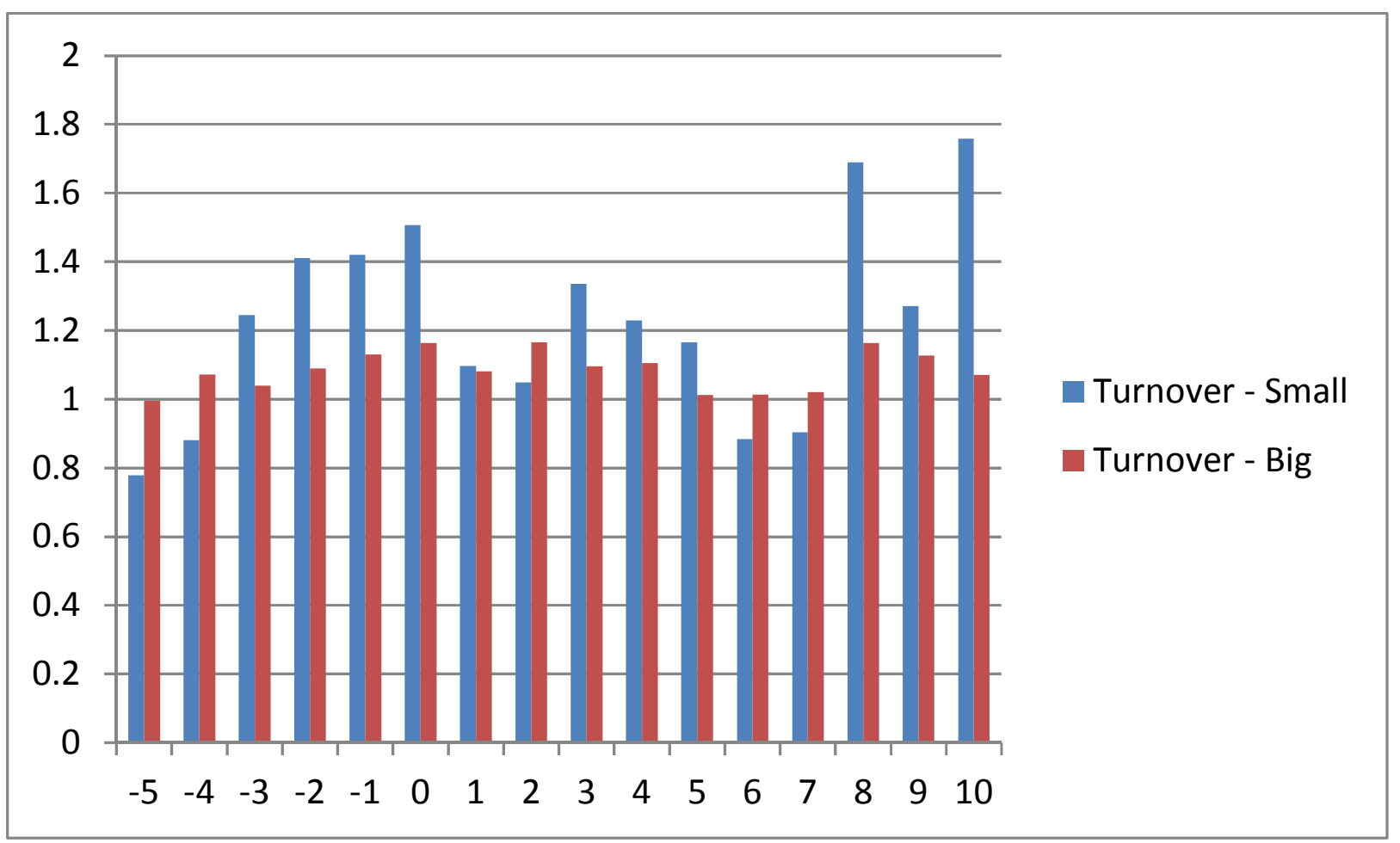

Figure 6 Turnover Ratios for Firms with Are Involved with Serious Tax-related News Stories and with Expatriations

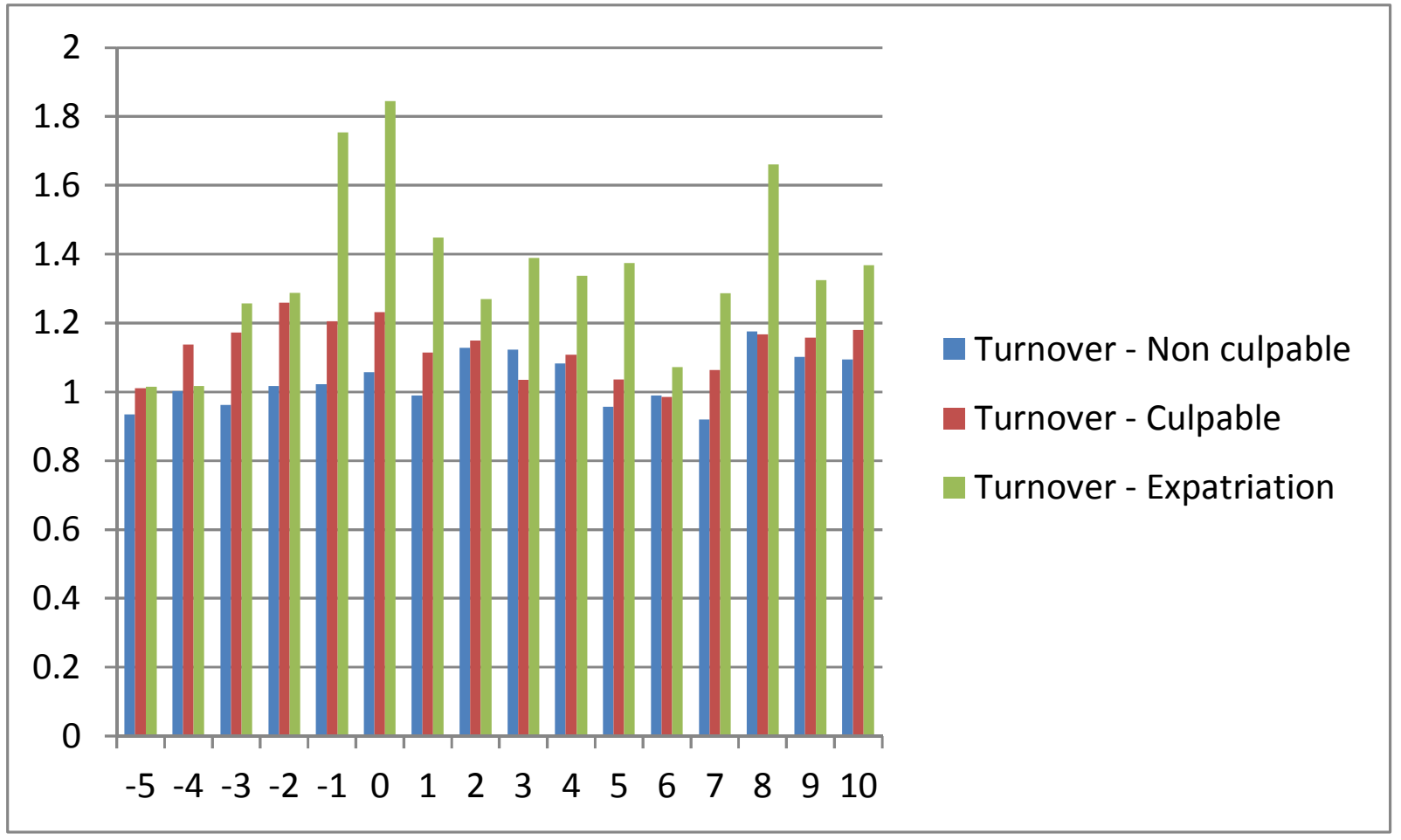

